HYDROLOGY OF MODERN AND LATE HOLOCENE

LAKES, DEATH VALLEY, CALIFORNIA

By DENNIS N. GRASSO

U.S. GEOLOGICAL SURVEY

Water-Resources Investigations Report 95-4237

Prepared in cooperation with the

NEVADA OPERATIONS OFFICE,

U.S. DEPARTMENT OF ENERGY under

Interagency Agreement DE-Al08-92NV10874

Denver, Colorado

1996 


\section{U.S. DEPARTMENT OF THE INTERIOR BRUCE BABBITT, Secretary \\ U.S. GEOLOGICAL SURVEY \\ Gordon P. Eaton, Director}

The use of trade, product, industry, or firm names is for descriptive purposes only and does not imply endorsement by the U.S. Government.

For additional information write to:

Chief, Earth Science Investigations Program

Yucca Mountain Project Branch

U.S. Geological Survey

Box 25046, MS 421

Denver Federal Center

Denver, CO 80225
Copies of this report can be purchased from:

U.S. Geological Survey

Information Services

Box 25286

Denver Federal Center

Denver, CO 80225 


\section{CONTENTS}

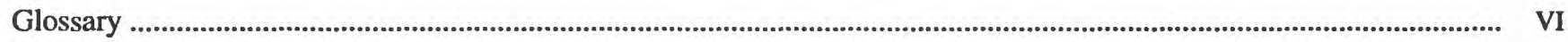

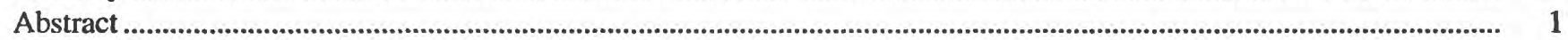

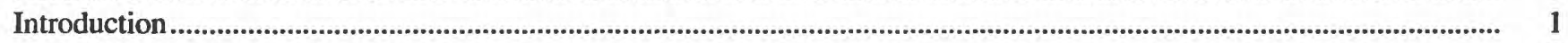

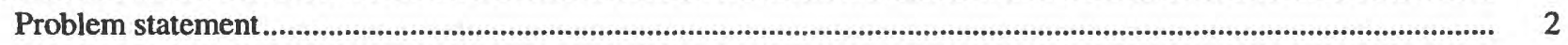

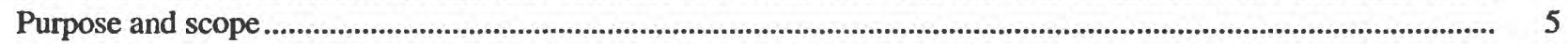

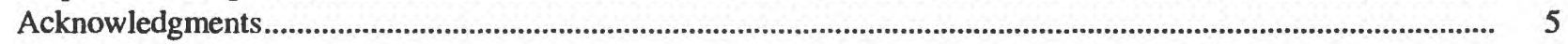

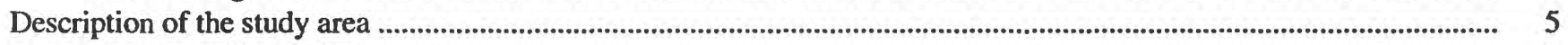

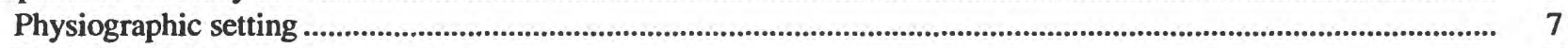

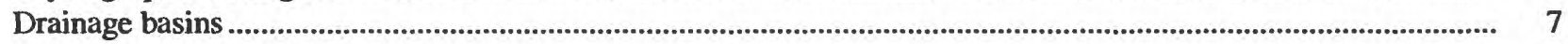

Upper Amargosa River Basin ..................................................................................................................... 8

Lower Amargosa River Basin ................................................................................................................... 8

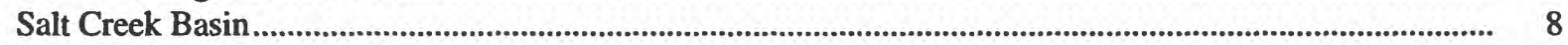

Alluvial-fan drainage basins .................................................................................................................... 10

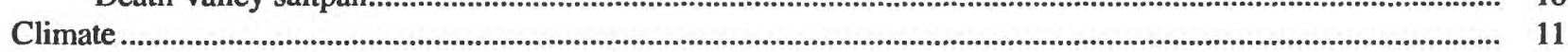

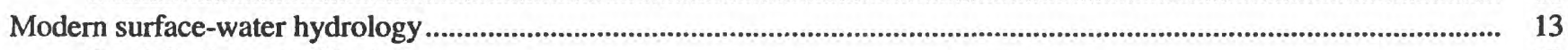

Precipitation-runoff relations ............................................................................................................................... 13

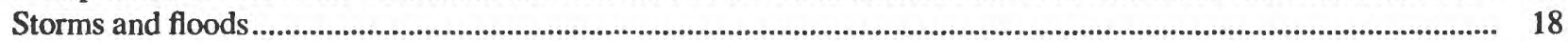

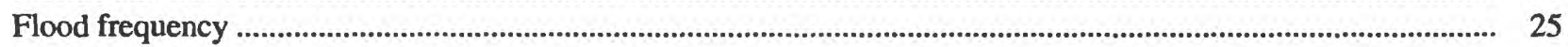

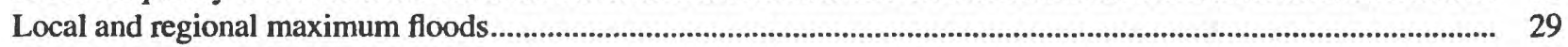

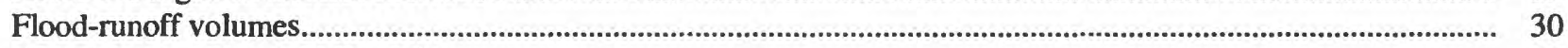

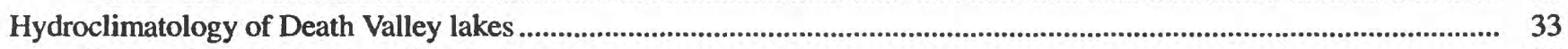

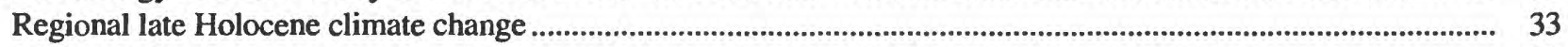

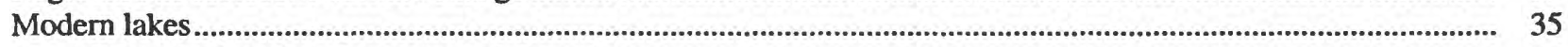

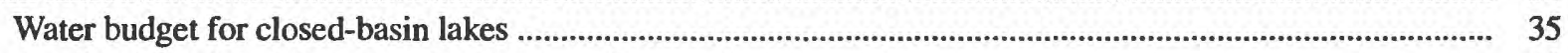

Application of the lake-water-budget equation ..................................................................................... 39

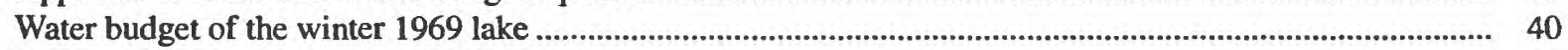

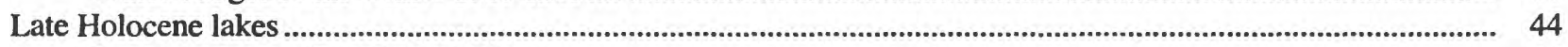

Regional hydroclimatic conditions ..................................................................................................... 44

Hydroclimatic simulations for a late Holocene perennial lake .................................................................. 45

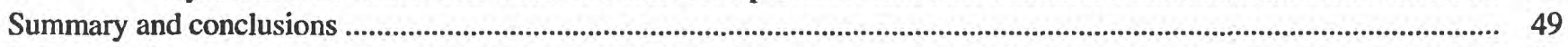

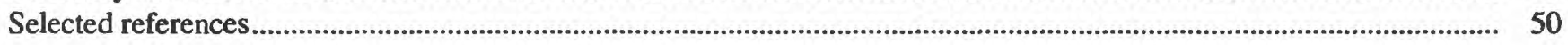

\section{FIGURES}

1. Photographs showing the winter 1993 lake in Death Valley ........................................................................ 3

2. Map showing the Death Valley watershed study area in southern Nevada and southeastern California .............. 6

3. Photographs showing oblique views of the alluvial braid plain at the terminus of the Amargosa River in southern Death Valley

4. Map showing the predominant path of storms and the approximate period of their effect during an average year for the Death Valley watershed study area.

5. Graph showing maximum and average monthly runoff and the year that the maximum monthly runoff occurred from the upper Amargosa River Basin, as recorded on the Amargosa River at Tecopa, California, 1962-83.

6. Map showing the locations of National Oceanic and Atmospheric Administration and Nevada Test Site weather stations in Nevada and California that were used to interpolate the monthly and seasonal distributions of precipitation over the Death Valley watershed. 
7-9. Graphs showing:

7. Estimated cumulative precipitation during winter (November-April) and summer (May-October) seasons over the upper Amargosa River Basin, 1962-83, and the occurrences of El Nino-

Southern Oscillation

8. Seasonal runoff during winter (November-April) and summer (May-October) seasons

from the upper Amargosa River Basin, as recorded on the Amargosa River at Tecopa,

California, 1962-83, and the occurrences of El Nino-Southern Oscillation

9. Seasonal precipitation runoff and linear trends for winter (November-April) and summer (May-October) season storms over the upper Amargosa River Basin, 1962-83.

10. Hydrograph of the Amargosa River, August 12-30, 1983, showing daily rainfall at Nevada Test Site weather station $4 \mathrm{JA}$, in inches, and daily mean discharge at Tecopa, California, in cubic feet per second

11. Isohyetal map showing the distribution of August 1983 precipitation over the Death Valley watershed in southern Nevada and southeastern California

12. Hydrograph of the Amargosa River, February 17-March 7,1969, showing daily rainfall at Nevada Test Site weather station 4JA, in inches, and daily mean discharge at Tecopa, California, in cubic feet per second.

13. Isohyetal map showing the distribution of February-March 1969 precipitation over the Death Valley watershed in southern Nevada and southeastern California

14. Map showing track of Hurricane Kathleen, September 6-10, 1976, and associated rainfall over the Southwestern United States.

15. Hydrograph of the Amargosa River, September 1-October 15, 1976, showing daily rainfall at Nevada Test Site weather station 4JA, in inches, and daily mean discharge at Tecopa, California, in cubic feet per second

16-18. Graphs showing:

16. Peak discharge and recurrence interval of recorded and estimated streamflows greater than

100 cubic feet per second for the Amargosa River at Tecopa, California

17. Envelope curves of the potential local and regional maximum floods from different-size drainage

basins in the Southwestern United States

18. Linear relations of recorded runoff to peak discharge for 34 streamflow periods of the

Amargosa River at Tecopa, California, 1968-83

19. Map showing late Pleistocene freshwater lakes and rivers in the southern Great Basin and

Mojave Desert areas of Nevada and California.

20. Graph showing monthly evaporation and average monthly temperature recorded in Death Valley, 1990 ........... 38

21. Diagrammatic sketch of the Death Valley watershed showing input and output sources of lake water .............. 39

22. Isohyetal map showing the distribution of winter 1969 precipitation over the Death Valley watershed in southern Nevada and southeastern California

23. Graph showing different combinations of increased lake-water inputs (precipitation, runoff, and spring discharge) and decreased lake evaporation required to produce and maintain a late Holocene perennial lake in Death Valley.

\section{TABLES}

1. Physical properties of drainage basins comprising the Death Valley watershed in southern Nevada and southeastern California.

2. Weather stations in southern Nevada and southeastern California used for precipitation mapping and analysis of the Death Valley watershed.

3. Ten largest storm runoff periods recorded for the Amargosa River at Tecopa, California, 1962-83, ranked in order of decreasing volume.

4. Peak discharge, daily mean discharge, streamflow duration and discharge volume, and the partialduration series, flood-frequency-analysis parameters for 68 streamflow events of the Amargosa River at Tecopa, California, 1962-83 
5. Estimated peak discharge, runoff volume, and unit area runoff for different-size floods on the Amargosa River at Tecopa, California, and the estimated runoff volume from drainage basins of the Death Valley watershed.

6. Regional lacustrine, hydrologic, and biogeographic evidence of early Neoglacial climate change in nonglacial areas of the Western United States

7. Regional lacustrine, hydrologic, and biogeographic evidence of late Neoglacial climate change in nonglacial areas of the Western United States

8. Annual evaporation from ephemeral and perennial lakes and reservoirs in southeastern California and southern Nevada.

9. Lake-water budget and hydroclimatic parameters of the winter 1969 lake in Death Valley, California

10. Hydroclimatic simulations and lake-water budgets for a late Holocene lake in Death Valley compared to the winter 1969 lake

\section{CONVERSION FACTORS, ACRONYMS, AND VERTICAL DATUM}

\begin{tabular}{rcl}
\hline Multiply & By & To obtain \\
\hline acre & 4,047 & \\
acre & 0.4047 & square meter \\
hectare & cubic meter \\
acre-foot (acre-ft) & 1,233 & cubic hectometer \\
acre-foot (acre-ft) & 0.001233 & cubic meter per second \\
cubic foot per second (ft $\left.{ }^{3} / \mathrm{s}\right)$ & 0.02832 & acre-ft/d \\
cubic foot per second (ft $\left.\mathrm{ft}^{3} / \mathrm{s}\right)$ & 1.9835 & meter \\
foot (ft) & 0.3048 & meter per kilometer \\
foot per mile (ft/mi) & 0.1894 & millimeter (mm) \\
inch (in.) & 25.4 & centimeter $(\mathrm{cm})$ \\
inch (in.) & 2.54 & years \\
ka (kilo-annum) & 1,000 & kilometer \\
mile (mi) & 1,609 & square kilometer \\
square mile (mi $\left.{ }^{2}\right)$ & 2.590 & \\
\hline
\end{tabular}

Degree Fahrenheit $\left({ }^{\circ} \mathrm{F}\right)$ may be converted to degree Celsius $\left({ }^{\circ} \mathrm{C}\right)$ by using the following equation:

$$
{ }^{\circ} \mathrm{C}=5 / 9\left({ }^{\circ} \mathrm{F}-32\right) \text {. }
$$

Acronyms:

NOAA National Oceanic and Atmospheric Administration

NTS Nevada Test Site

Sea level: In this report "sea level" refers to the National Geodetic Vertical Datum of 1929 (NGVD of 1929)-a geodetic datum derived from a general adjustment of the first-order level nets of both the United States and Canada, formerly called Sea Level Datum of 1929. 


\section{GLOSSARY}

Alluviation.-The subaerial deposition or formation of alluvium or alluvial features at places where stream velocity is decreased or streamflow is checked; the process of aggradation or of building up of sediments by a stream along its course or of covering or filling a surface with alluvium.

Altithermal._A term proposed by Antevs (1948, p. 176) for a dry post-glacial interval about 7,500 to 4,000 years ago during which temperatures were warmer than present and precipitation may have been lower.

Base flow.-The sustained or fair-weather flow of a stream; that part of stream discharge that is principally the result of ground-water flow into a stream.

Braid plain.-An alluvial flood plain formed by an anastomosing or braided stream.

Direct precipitation.-Precipitation that falls directly onto a lake or stream without passing through any land phase of the runoff cycle.

Evapotranspiration.-Loss of water from a land area through transpiration of plants and evaporation from the soil and surface-water bodies. Also, the volume of water lost through evapotranspiration.

Fluvial.-Pertaining to, produced by, or formed by a river or rivers.

Holocene.-An epoch of the Quaternary period, from the end of the Pleistocene, approximately 10,000 years ago, to the present time. When the Quaternary is designated as an era, the Holocene is considered to be a period.

Hydrograph.-A graph showing stage, velocity, flow, or other characteristics of ground water or surface water as a function of time.

Infiltration.-The movement of water into soil, sediment, or porous rock.

Infiltration rate.-The rate at which a soil under specific conditions can absorb falling rain or melting snow; expressed in depth or water per unit time.

Interflow.-The lateral movement of water in the unsaturated zone during and immediately after a storm; water that moves as interflow commonly discharges directly into a stream or lake.

Interpolation.-Estimation of the value of a variant based on two or more known surrounding values; a method used to determine intermediate values between known points on a line or curve. Interpolation requires that certain assumptions be made about the quantity between two known (measured) values. Numerical algorithms used to interpolate values include inverse distance squared, minimum curvature, theissen polygons, and kriging; the latter a statistical technique that has received widespread attention in the geosciences.
Isohyet.-A line connecting points of equal precipitation drawn as contour lines over land or water on a map. An isohyetal map uses these lines to show the distribution of precipitation over an area.

Kriging.-A statistical interpolation technique using inferential statistics to establish a regularly-spaced grid of surface values from irregularly-spaced sites of known quantity (Monmonier, 1982; Delfiner and Delhomme, 1975). Kriging is said to be the most accurate method for determining the distribution of the effective uniform depth of precipitation over a drainage basin from a nonuniform distribution of rain gages (Abtew and others, 1993; Fetter, 1988). The method is named for Danie

Krig, a South African geostatistician. Isohyet maps of rainfall distribution over the Southwestern United States (this paper) were prepared using kriging applied to precipitation data from an array of irregularly spaced NOAA weather stations. Precipitation volumes (in acre-feet) received by drainage basins for monthly and seasonal events were computed from interpolated grid using digitized drainage boundaries and a numerical integration method known as the Trapezoidal Rule.

Lacustrine.-Pertaining to, produced by, or formed in a lake or lakes; for example, lacustrine sediment.

Little Ice Age.-A cool, brief interval in an otherwise warm interglacial stage; originally used for a mid-Holocene event (about 3,000 years ago) in the Yosemite area, California (Matthes, 1930); widely used for the 16thand 18th-century cool phases.

Medithermal.-A term used by Antevs (1948, p. 176) for the period of time in the late Holocene marked by decreasing temperatures.

Neoglacial period(s).- Those time periods of the Holocene marked by the re-advancement of mountain glaciers. Commonly referred to simply as Neoglacial.

Outflow. - Water that flows out of a lake or drainage basin, for example, by seepage to the water table.

Overland flow.-That part of surface runoff flowing over land surfaces toward stream channels; after entering a stream channel, overland flow becomes part of the total runoff. Overland flow begins when the rate of precipitation exceeds the infiltration rate of a basin's soil and the depression storage is full.

Paludal.-Pertaining to, produced by, or formed in a marsh. Playa (playa lake; playa lake flat).-A dry, vegetation-free, flat at the lowest part of an undrained (or internally drained) desert basin in the Southwestern United States that is generally composed of, or underlain by, stratified lacustrine clay, silt, sand, and soluble salts. Many playa basins in the Southwest contain ephemeral lakes.

Pluvial.-Pertaining to, or said of, a geologic episode, change, process, deposit, or feature resulting from the action or effects of rain. Pertaining to rainy events, such as pluvial events, pluvials, or pluvial lakes, or 
sedimentary deposits, such as pluvial lake deposits formed by rain and runoff from ephemeral streams.

Pluvial lake.-A lake formed in a period of exceptionally heavy rainfall, such as the late Pleistocene, that is now either extinct or existing as a remnant.

Saltpan.-An undrained shallow natural depression in which water accumulates and evaporates, leaving a salt deposit. Also, a shallow lake of brackish water occupying a saltpan.

Streamflow (channel flow).-Movement of surface runoff in long narrow depressions or troughs bounded by banks or valley walls that slope toward the channel.
Underflow.-Water that flows beneath the bed or alluvial plain of a surface stream, generally in the same direction as, but at a much slower rate than, the surface drainage; especially the water that flows under a dry stream channel in an arid region.

Watershed.-The region drained by, or contributing to, a stream, lake, or other body of water. The Death Valley watershed includes all contributing drainages that flow into Death Valley at the lowest elevation of the watershed or streams that are tributaries of drainages that flow into Death Valley. 


\title{
Hydrology of Modern and Late Holocene Lakes, Death Valley, California
}

\author{
By Dennis N. Grasso
}

\section{Abstract}

Above-normal precipitation and surfacewater runoff, which have been generally related to the cyclic recurrence of the El Nino-Southern Oscillation, have produced modern ephemeral lakes in the closed-basin Death Valley watershed. The principal source of water for these extensive, but shallow lakes is the Amargosa River. The Amargosa River Basin comprises approximately two-thirds of the 8,533-square-mile Death Valley watershed, includes large tributary areas in the Yucca Mountain site area, and terminates in Death Valley. Periodic flooding on the Amargosa River has therefore, been dynamically related to the production of lakes at its terminus in Death Valley.

This study evaluates the regional hydroclimatic relations between precipitation, runoff, and lake transgressions in the Death Valley watershed. Recorded precipitation, runoff, and spring discharge data for the region are used in conjunction with a closed-basin, lake-water-budget equation to assess the relative contributions of water from these sources to modern lakes in Death Valley and to identify the requisite hydroclimatic changes for a late Holocene perennial lake in the valley.

The results of the study indicate that modern hydroclimatic conditions favor only small latewinter lakes that quickly desiccate in spring to early summer due to high temperature and evaporation. The existence of winter lakes in 1969 and 1993 indicates that modern lakes are produced by either large-magnitude floods or frequent lowmagnitude runoff from the watershed.

Empirical hydroclimatic simulations of a 223-square-mile, late Holocene perennial lake in Death Valley indicate that extreme changes in climate and hydrology were necessary to produce and maintain this lake. The late Holocene lake, which was the size of modern-day Lake Mead (about 142,000 acres), could have been produced in 12 years and maintained indefinitely by a sustained 200-percent increase in precipitation, runoff, and spring discharge; a four-fold increase in the average runoff-to-rainfall ratio of the watershed (from 1.5 to 6.0 percent); and a 50-percent reduction in annual lake evaporation. Because these conditions would have been extreme for the period, a more acceptable combination of change, including increased precipitation-runoff, decreased evaporation, and a higher water table are indicated.

\section{INTRODUCTION}

As part of the Yucca Mountain Site Characterization Program, an evaluation of the Quaternary regional paleoflood hydrology of the potential nuclear-waste repository site at Yucca Mountain, Nevada, was planned. The objectives of the evaluation were (1) to identify the locations and investigate the hydraulic characteristics of paleofloods and compare these with the locations and characteristics of modern floods, and (2) to evaluate the character and severity of past floods and debris flows to ascertain the potential future hazards to the potential repository during the pre-closure period (U.S. Department of Energy, 1988).

This study addresses the first of these objectives, and the second in part, by assessing and comparing the sizes, locations, and recurrence rates of modern, recorded (1962-83) floods and late Holocene paleofloods for the 8,533- $\mathrm{mi}^{2}$, closed-basin, Death Valley watershed with its contributing drainage basins in the Yucca Mountain site area. The study focuses on how the amounts and distributions of regional precipitation are related to ephemeral streamflow and lakes in the watershed and whether large-magnitude paleofloods occurred more frequently during a late Holocene lacustrine episode that occurred 2,000 to 5,000 years ago (2-5 ka). As a means for investigating the regional 
precipitation-runoff conditions and hydraulic characteristics of modern streamflows and paleofloods, the regional hydroclimatology of two lacustrine episodes, a modern lake episode that occurred in the winter of 1969 (Hunt, 1975) and a paleolake episode that occurred during a Neoglacial period of the late Holocene (Hunt, 1966) were analyzed and compared. These lake-forming episodes are important to this investigation because a direct correspondence can be established between regional precipitation-runoff and the formation of lakes in the closed-basin Death Valley watershed.

The correspondence of precipitation-runoff and lake formation in the Death Valley watershed was most recently observed in the winter of 1993 when a large, ephemeral lake was produced by above-normal rainfall and sustained runoff on the Amargosa River (fig. 1). This lake and the recurrence of other short-lived lakes in Death Valley during the past three decades (1963-93) demonstrate what paleohydrologic conditions may have been like in the late Holocene when a more sizable perennial lake (Hunt, 1966; 1975) occupied Death Valley. An important difference is that these modern winter lakes will quickly desiccate when rainfall-runoff cease and high summer temperatures and concomitant high rates of lake evaporation return to the valley. The winter 1993 lake (fig. 1) was completely dry by May 15, 1993, whereas Hunt (1975) indicated that the larger late Holocene lake may have persisted for nearly 100 years.

Historically, periods of above-normal precipitation and runoff have been generally correlative throughout the Southwestern United States with the cyclical recurrence of the El Nino-Southern Oscillation (ENSO) (Ropelewski and Halpert, 1986, 1989; Schonher and Nicholson, 1989; D'Arrigo and Jacoby, 1991; Ely and others, 1994; Kahya and Dracup, 1994). In the Great Basin, for example, above-normal precipitation has occurred during 12 of 14 ENSO years between 1922 and 1983 (Ropelewski and Halpert, 1986). Increased streamflows related to the ENSO (Kahya and Dracup, 1994) have caused widespread flooding and the formation of lakes in many of the hydrologically closed basins that characterize the Southwest deserts. However, unlike the ancestral lakes that once filled these same basins during the late Pleistocene and late Holocene, these modern ephemeral lakes have been considerably smaller in areal size and depth.
Throughout the late Quaternary, hydrologic conditions in the deserts of southern Nevada and southeastern California have fluctuated widely in response to regional climate change (Smith and Street-Perrott, 1983; Enzel and others, 1988). In late Holocene, periods of increased precipitation have resulted in frequent, high-magnitude runoff (Ely and others, 1993) and an ensuing rise in the level of closed-basin pluvial lakes (Brown and others, 1989). Conversely, intervening periods of decreased precipitation have resulted in less frequent floods, lake desiccation, and prolonged drought.

In Death Valley, Hunt $(1966 ; 1975)$ recognized that above-normal precipitation produced local flooding and shallow lakes that have inundated the Death Valley saltpan. On the basis of these modern hydroclimatic conditions, he reasoned that past climatic conditions must have been notably wetter to have produced and maintained the large, late Holocene lake that is evidenced by the surficial geologic record of Death Valley. One such wetter climatic period that occurred during the late Holocene (2-5 ka) caused widespread alluviation along the Amargosa River and reportedly produced an extensive lake in Death Valley (Hunt, 1975, p. 14). Although the lake was shallow and may have existed in Death Valley for less than about 100 years (Hunt, 1975), this late Holocene lake would have been slightly larger than modern-day Lake Mead (about 142,000 acres) and would have persisted long enough to form the Death Valley saltpan and the distinctive bathtub ring of shorelines that mark its former extent in the valley (fig. 1).

\section{Problem Statement}

The prior existence of a large, late Holocene perennial lake in the closed-basin Death Valley watershed presents an important regional hydroclimatic problem. First, what hydrologic changes were necessary to produce and maintain such a lake in this arid to hyperarid watershed. Second, were the regional climate changes of the late Holocene of sufficient magnitude to bring about such hydrologic changes.

As one of the hottest and most arid places on Earth, the Death Valley playa lake flat has a potential lake evaporation rate of about $82 \mathrm{in./yr}$ (Meyers, 1962). Under these conditions, the $223-\mathrm{mi}^{2}$ (142,000-acre) late Holocene lake would have lost about 970,000 acre-ft of water annually to evaporation. 
(A)

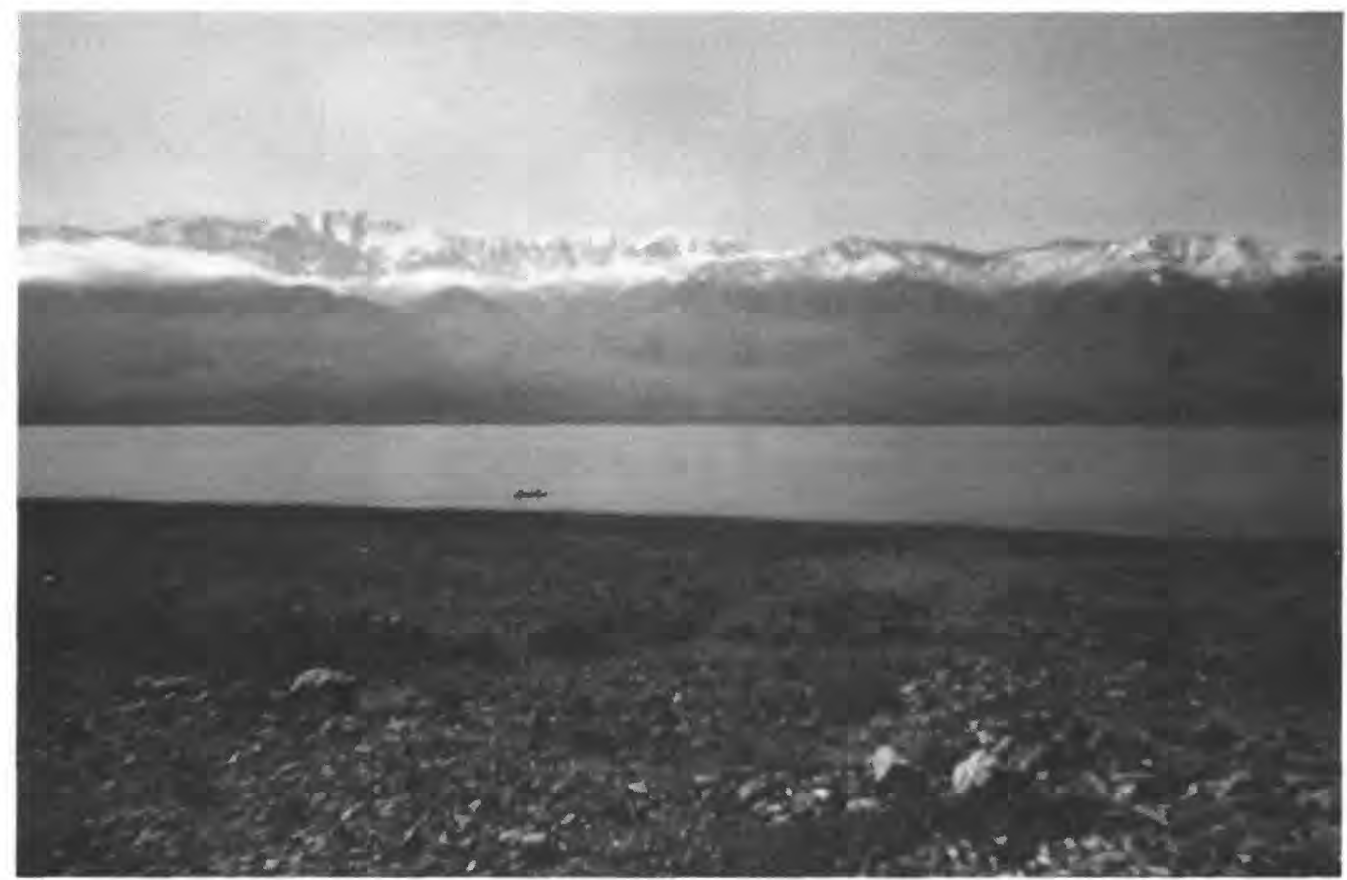

(B)

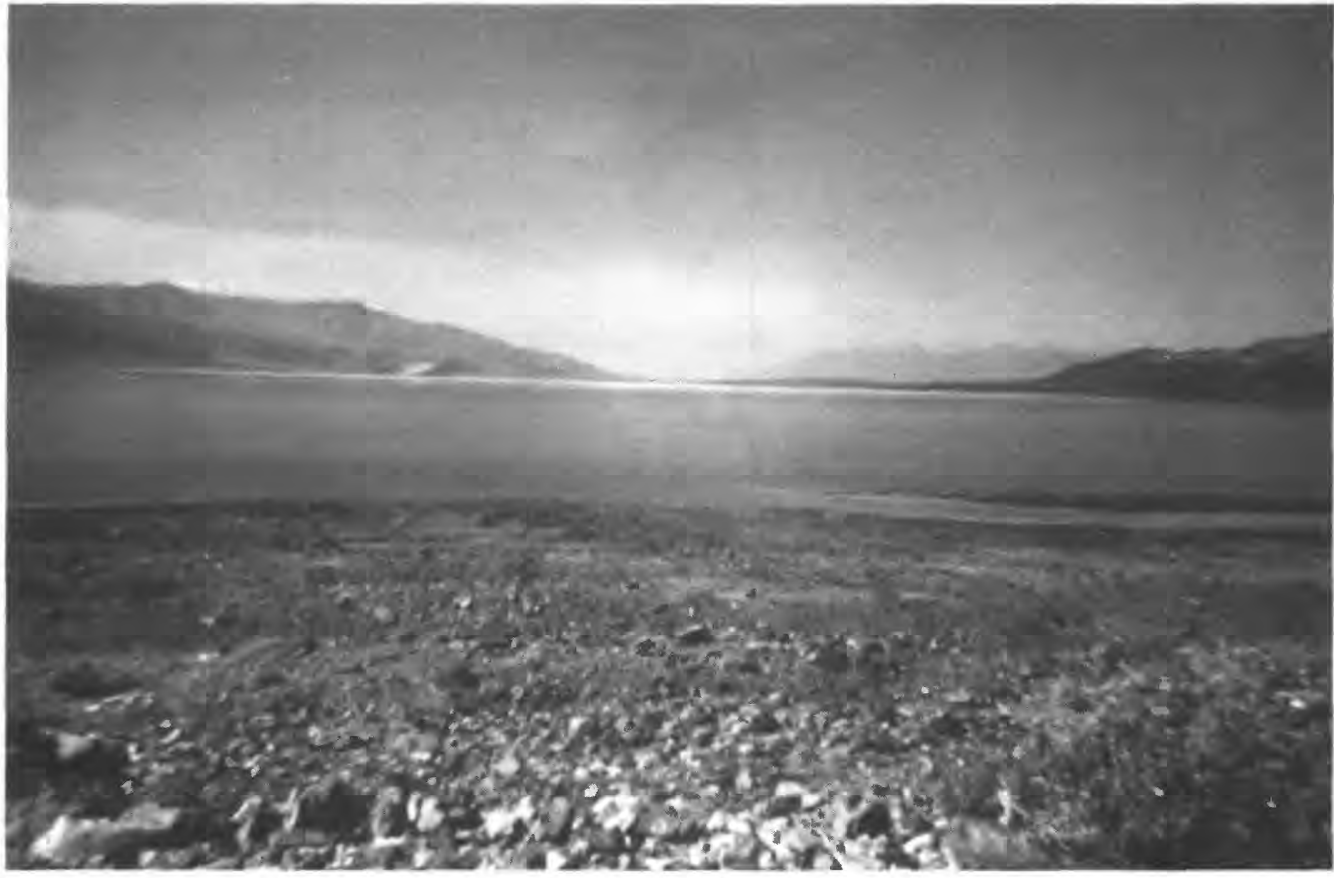

Figure 1. The winter 1993 lake in Death Valley. This lake was formed by heavy precipitation and runoff in January-March 1993. (A) View of lake to west (canoe in lake) from roadway south of Badwater, California; $(B)$ view of lake to northwest; $(C)$ view to southwest of mudflat at the highest level of modern ephemeral lakes (the mudflat is not flooded by the 1993 lake). Two shorelines, visible at left center of (C), mark the high-water levels of modern (lower) and late Holocene (higher) lakes. A rocky wash slope of the late Holocene lake is visible in the foregrounds of (A) and (B). Telescope Peak (11,049 ft) forms the snow-capped skyline on the west side of the valley in (A) and (C). (Photographs taken March 1, 1993.) 
(C)

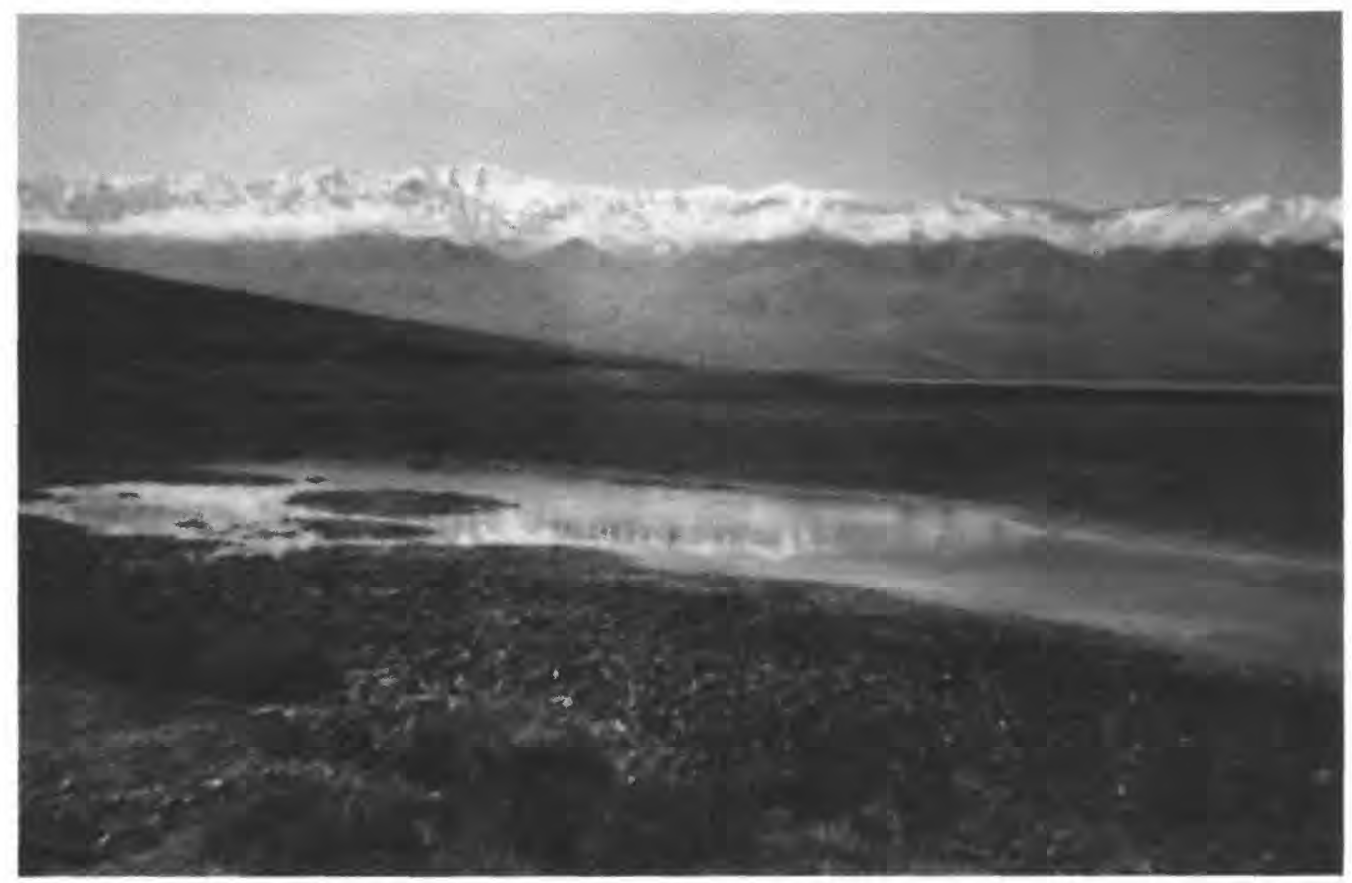

Figure 1. The winter 1993 lake in Death Valley. This lake was formed by heavy precipitation and runoff in January-March 1993. (A) View of lake to west (canoe in lake) from roadway south of Badwater, California; (B) view of lake to northwest; (C) view to southwest of mudflat at the highest level of modern ephemeral lakes (the mudflat is not flooded by the 1993 lake). Two shorelines, visible at left center of (C), mark the high-water levels of modern (lower) and late Holocene (higher) lakes. A rocky wash slope of the late Holocene lake is visible in the foregrounds of (A) and (B). Telescope Peak $(11,049 \mathrm{ft})$ forms the snow-capped skyline on the west side of the valley in (A) and (C). (Photographs taken March 1, 1993.)--Continued. 
Thus, to produce and maintain the late Holocene lake in Death Valley would have required either (1) a sizable increase in the volume of precipitation over the saltpan and runoff from the watershed, (2) a substantial decrease in temperature to reduce annual lake evaporation, or (3) a combination of these hydroclimatic changes (for example, an increase in the frequency or magnitude of precipitation and runoff combined with a decrease in temperature and lake evaporation).

This study assesses the nature of these late Holocene changes by evaluating modern (recorded) interactions between climate, surface-water runoff, and lakes in the Death Valley watershed during the period 1962-93. From these modern hydroclimatic conditions, scenarios for the formation and maintenance of a late Holocene perennial lake in Death Valley are presented.

\section{Purpose and Scope}

This report presents the results of a regional evaluation and comparison of the modern and paleoflood hydrologies of drainage basins comprising the Death Valley watershed. The cause-and-effect relations between the volume of precipitation and surface-water runoff of storms and seasonal events are analyzed, and the hydroclimatic parameters of two lake-forming periods, the winter of 1969 and the late Holocene, are compared. The report focuses on recorded precipitationrunoff characteristics of storms and floods, flood frequencies, and regional flood runoff of the Amargosa River (1962-83) because this river (1) drains the largest contributing drainage basin of the Death Valley watershed, (2) furnishes large amounts of surface water directly to Death Valley during heavy precipitationrunoff periods, (3) provides more than two decades of flood data for establishing numerical relations between precipitation, runoff, and lake-level rises at the terminus of the river in Death Valley, (4) provides modern analog information about the paleohydrology of the region, and (5) is fed by upland tributary streams that drain second-order drainage basins in and around Yucca Mountain, the site of a potential nuclear waste repository.

The hydroclimatology of a modern ephemeral lake in Death Valley is assessed and the contributions of precipitation, runoff, and spring discharge from individual drainage basins of the Death Valley watershed are evaluated using a closed-basin, lake-water-budget equation applied to the winter 1969 lake event. Hydroclimatic parameters for the winter 1969 lake are presented based on recorded and estimated hydrologic and climatic data for individual storms and seasonal conditions. The results of this quantitative modeling effort indicate the relative contributions of lake water from precipitation, runoff, and ground-water sources in the watershed; the limiting effects of lake evaporation; and why modern closed-basin lakes in Death Valley are ephemeral.

In the final section of this report, hydroclimatic scenarios for a large, late Holocene perennial lake in Death Valley are presented. Requisite streamflow conditions, flood volumes, and temperature and evaporation factors for the late Holocene lake are based on criteria derived from modern hydroclimatic data, onsite investigations of unusually wet seasonal conditions in the winters of 1992 and 1993, and on the results of the winter 1969 lake-water budget. These modern and ancestral fluvial and lacustrine events of the Death Valley watershed are important because they indicate the range of possible effects that climate change can have on the regional surface-water hydrology of desert streams that drain the Yucca Mountain site area.

\section{Acknowledgments}

The author wishes to thank the staff of the U.S. Geological Survey, Las Vegas, Nevada, for their support during the course of this study. Special thanks are due to Pat Glancy, Gary Dixon, Tom Kane, and Claire Martinez for their assistance in the field and with the preparation and analysis of climatic and hydrologic data used in this study.

\section{DESCRIPTION OF THE STUDY AREA}

The study area consists of the Death Valley watershed located in the southern Great Basin section of the Basin and Range physiographic province in southern Nevada and southeastern California (fig. 2).

The 8,533- $\mathrm{mi}^{2}$ Death Valley watershed is a closedbasin hydrologic system that contains a number of individual drainage basins that drain into and terminate in Death Valley at the lowest elevation of the watershed. In this report, the term watershed is used to describe the entire Death Valley closed-basin hydrologic system, and the phrase drainage basin is used to describe any of the contributing hydrologic basins that comprise the 


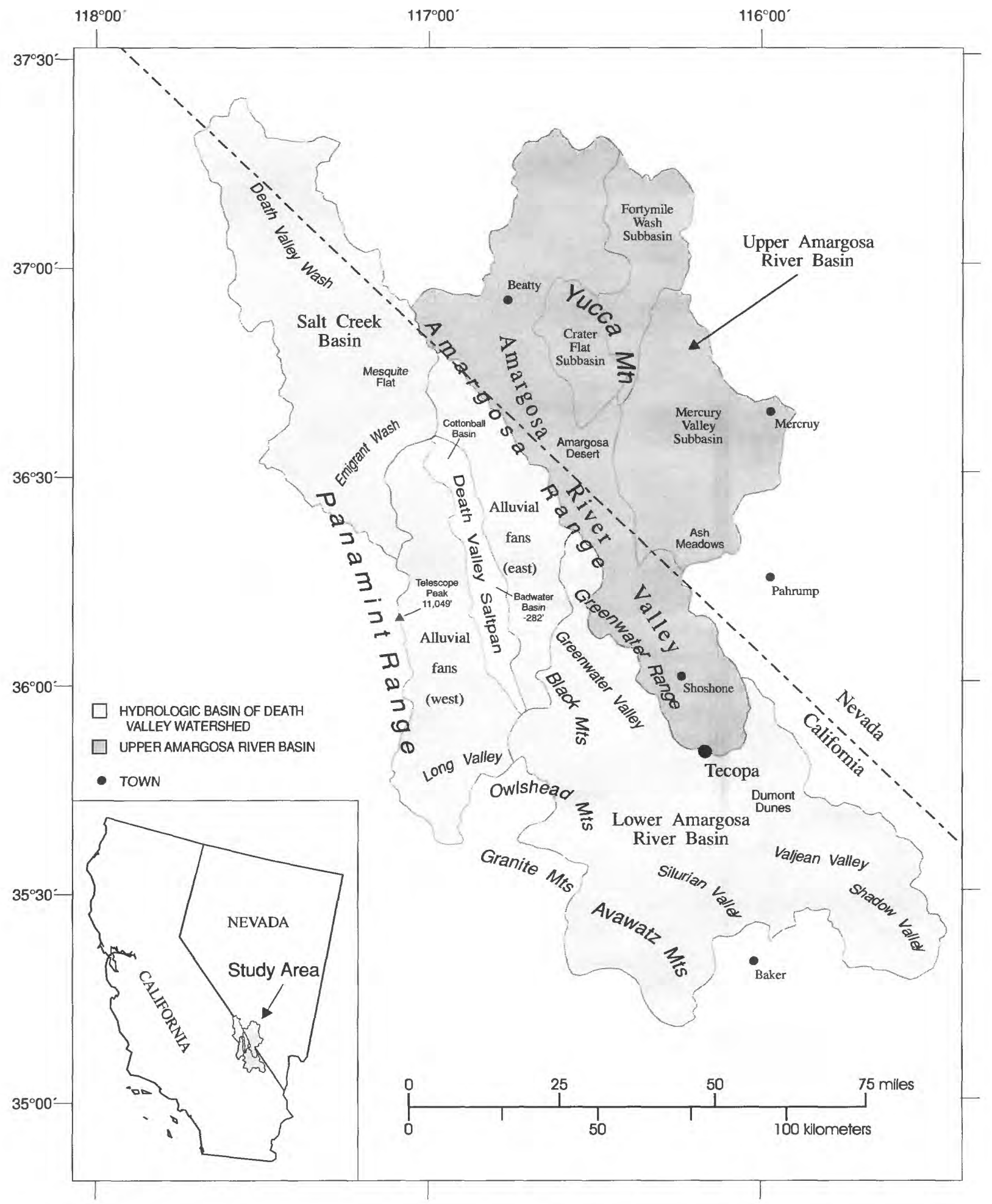

Figure 2. The Death Valley watershed study area in southern Nevada and southeastern California. 
watershed. The boundaries of the Death Valley watershed and its major contributing drainage basins are shown in figure 2.

\section{Physiographic Setting}

The geologic and hydrologic diversities of the study area are closely related to the geologic, tectonic, and geomorphic histories of the Great Basin with its many north-south trending fault-block mountains and down-dropped intermontane basins (Fenneman, 1931). Throughout the study area, Precambrian igneous and metamorphic intrusive (basement) rocks form the cores of mountain ranges. These rocks are overlain by thick sections of Paleozoic sedimentary strata, Mesozoic and Cenozoic intrusive, extrusive, and clastic rock formations, and extensive accumulations of alluvial, colluvial, and eolian sediments (Miller, 1977; Bedinger and others, 1989). The ranges and intervening valleys in the study area are part of the complex horst-and-graben structural framework of the Basin and Range. Of the many large, down-dropped, structural and topographic basins (grabens) that characterize the province, Death Valley is the deepest. The floor of Death Valley (the Death Valley saltpan) consists of a large, 223-mi ${ }^{2}$ saline playa lake flat that is mostly below sea level (fig. 2). In the Badwater Basin, at the center of the saltpan, Death Valley has a minimum elevation $-282 \mathrm{ft}$. From the mountains bordering the Death Valley saltpan, the Panamint Range to the west and the Amargosa Range to the east, coalescing alluvial fans (bajadas) stretch into the valley. The most recent Quaternary alluvial fan deposits extend out onto the saltpan and provide evidence of the ongoing nature of the flood and debris flow processes that have formed these fans in Death Valley. The highest point in the watershed is Telescope Peak at an elevation of $11,049 \mathrm{ft}$ in the Panamint Range (fig. 2). Between Telescope Peak and Badwater Basin (fig. 2), the maximum relief in the Death Valley watershed is $11,331 \mathrm{ft}$ (fig. 1a).

\section{Drainage Basins}

The Death Valley watershed contains two primary drainage basins, the Amargosa River Basin (upper and lower parts) and Salt Creek Basin, and two secondary drainage areas of the bajadas that border the Death Valley saltpan (fig. 2). All of the streams that drain these hydrologic basins terminate in Death Valley. Detailed descriptions of the hydrology and water resources of the Death Valley watershed are given in Hunt (1966; 1975), Hunt and others (1966), Miller (1977), and Bedinger and others (1989).

The Amargosa River drains the largest area of the Death Valley watershed (table 1). The Amargosa River Basin makes up 66.7 percent $\left(5,546 \mathrm{mi}^{2}\right)$ of the Death Valley watershed catchment $\left(8,310-\mathrm{mi}^{2}\right)$ and includes second-order tributary basins (Fortymile Wash, Crater Flat, and Mercury Valley) in the Yucca Mountain site area. For this study, the Amargosa River Basin was divided into upper and lower parts (fig. 2). The larger, upper Amargosa River Basin (3,090-mi $)$, is located east-northeast of Death Valley and upstream of Tecopa, California, the site of a U.S. Geological Survey streamflow-gaging station during water years 1962-83 and 1992-present (1995). The smaller, lower Amargosa River Basin $\left(2,456-\mathrm{mi}^{2}\right)$ is the remainder of the Amargosa River Basin downstream from Tecopa, California (fig. 2).

Table 1. Physical properties of drainage basins comprising the Death Valley watershed in southern Nevada and southeastern California

[mi ${ }^{2}$, square miles; ---, not applicable]

\begin{tabular}{|c|c|c|c|}
\hline $\begin{array}{c}\text { Drainage-basin } \\
\text { name }\end{array}$ & $\begin{array}{l}\text { Area } \\
\left(\mathbf{m i}^{2}\right)\end{array}$ & $\begin{array}{c}\text { Area } \\
\text { (acres) }\end{array}$ & $\begin{array}{c}\text { Percentage } \\
\text { of } \\
\text { catchment }^{1}\end{array}$ \\
\hline $\begin{array}{l}\text { Upper Amargosa } \\
\text { River Basin }\end{array}$ & 3,090 & $1,977,600$ & 37.2 \\
\hline $\begin{array}{l}\text { Lower Amargosa } \\
\text { River Basin }\end{array}$ & 2,456 & $1,571,840$ & 29.5 \\
\hline Salt Creek Basin & 1,450 & 928,000 & 17.5 \\
\hline Alluvial fans (west) & 780 & 499,200 & 9.4 \\
\hline Alluvial fans (east) & $\underline{534}$ & $\underline{341,760}$ & $\underline{6.4}$ \\
\hline Total catchment & 8,310 & $5,318,400$ & 100.0 \\
\hline Death Valley saltpan & $\underline{223}$ & $\underline{142.720}$ & --- \\
\hline Total watershed & 8,533 & $5,461,120$ & -- \\
\hline $\begin{array}{l}\text { Amargosa River } \\
\text { Basin }^{2}\end{array}$ & 5,546 & $3,549,440$ & 66.7 \\
\hline $\begin{array}{l}{ }^{1} \text { Percentage of cat } \\
\text { relative to the total surfa } \\
\text { ment. The Death Valley } \\
{ }^{2} \text { Amargosa River } \\
\text { defined in this report and } \\
\text { total catchment area of th }\end{array}$ & $\begin{array}{l}\text { ment is the } \\
\text { area of th } \\
\text { tpan is no } \\
\text { in include } \\
\text { mprises tv }\end{array}$ & $\begin{array}{l}\text { Irface area of } \\
\text { Death Valley } \\
\text { cluded in catc } \\
\text { he upper and } t \\
\text { thirds ( } 66.7 \mathrm{p} \\
\text { watershed. }\end{array}$ & $\begin{array}{l}\text { drainage basin } \\
\text { mershed catch- } \\
\text { ment. } \\
\text { lower parts as } \\
\text { cent) of the }\end{array}$ \\
\hline
\end{tabular}




\section{Upper Amargosa River Basin}

The upper Amargosa River Basin includes 37.2 percent $\left(3,090 \mathrm{mi}^{2}\right)$ of the Death Valley watershed catchment (table 1) and includes four upland tributary basins: (1) the Amargosa River headlands upstream from Beatty, Nevada; (2) Fortymile Wash and its tributaries east of Yucca Mountain; (3) Crater Flat and its tributaries west of Yucca Mountain; and (4) tributaries that drain Mercury Valley (fig. 2). Ephemeral streams from these basins flow across extensive alluvial flats and converge to flow into the Amargosa River. Southsouthwest of Yucca Mountain, the Amargosa River flows southward across a broad desert basin of marshes, playa lake flats, and sand dunes in the Amargosa Desert. Throughout its course in the Amargosa Desert, the Amargosa River flows in a broad (braided) flood plain about 0.5 -mi wide, crosses saline lake deposits of Franklin Lake playa, and descends into an entrenched channel southwest of Ash Meadows (fig. 2). For the remainder of its course to Tecopa, the Amargosa River flows in an entrenched channel that truncates the toes of Quaternary alluvial fans and cuts uplifted lacustrine lake beds of the middle Pleistocene (1,900-700 ka) Tecopa Lake between the towns of Shoshone and Tecopa, California (Woodburne, 1991).

\section{Lower Amargosa River Basin}

The lower Amargosa River Basin includes 29.5 percent $\left(2,456 \mathrm{mi}^{2}\right)$ of the Death Valley watershed catchment (table 1) and is a continuation of the upper Amargosa River Basin. The lower Amargosa River Basin contains ephemeral streams that flow from Greenwater Valley, Shadow and Valjean Valleys, Silurian Valley, Long Valley, and local alluvial-fan drainage basins from the Avawatz, Granite, and Owlshead Mountains and the southern Panamint Range (fig. 2). Downstream from Tecopa, California, the Amargosa River flows southward past the Dumont Dunes and turns sharply west and north before terminating at the southern end of the Death Valley saltpan.

Although little water flows from the many contributing subbasins of the lower Amargosa River Basin, Salt Creek (south) in Silurian Valley may have been a prior conduit for the Mojave River during a pluvial-maximum lake episode in late Pleistocene (Smith and Street-Perrott, 1983; Enzel and others, 1988). Since the desiccation of this late Pleistocene lake, however, this surface-water connection between the Mojave River and the Death Valley watershed has been blocked by a topographic divide north of Silver Lake playa at the terminus of the Mojave River near Baker, California. Therefore, surface water that flows into the Amargosa River from Silurian Valley is derived only from local alluvial-fan runoff from the Avawatz Mountains on the west and ephemeral streamflow from Shadow and Valjean Valleys to the southeast.

A second possible late Pleistocene, surfacewater conduit is located near the terminus of the lower Amargosa River Basin in Death Valley. Here, Wingate Wash in Long Valley, which extends eastward to the Amargosa River (fig. 2), has been identified as the most likely route for late Pleistocene streamflow of the Owens River into Death Valley (Smith and StreetPerrott, 1983). This connection may have been possible during the late Pleistocene when Panamint Lake to the west of the Panamint Range filled to the level of Windgate Pass and spilled over into Death Valley. Subsequent to the demise of Panamint Lake, however, Windgate Wash in Long Valley only drains local ephemeral runoff from the southern Panamint Range and northern Owlshead Mountains.

The Amargosa River near its terminus in Death Valley flows as a braided stream across a broad alluvial flood plain that merges into the Death Valley saltpan (fig. 3A). According to Hunt (1966, p. A86), the flood plain was deposited ". . . about the time of the Recent [late Holocene] lake ..." in Death Valley (2-5 ka). Since that time, the main channel of the Amargosa River has become entrenched by as much as $10 \mathrm{ft}$; deflation hollows have formed on the flood plain; aeolian sheet and dune sands have buried the surface of the flood plain in places; and locally derived alluvial fan (debris-flow) and slope (colluvial) deposits have accumulated along the margins of the Amargosa River flood plain in Death Valley.

\section{Salt Creek Basin}

Salt Creek Basin includes 17.5 percent $\left(1,450-\mathrm{mi}^{2}\right)$ of the Death Valley watershed catchment (table 1) and drains that part of the watershed north of the Death Valley saltpan (fig. 2). The basin comprises two subbasin, Death Valley Wash to the north and Emigrant Wash to the west (fig. 2). Ephemeral streams of these arid subbasins flow across the low-lying basin area of Mesquite Flat (elevation range of about 800 to $-200 \mathrm{ft}$ ) and join Salt Creek (north), which eventually 
(A)

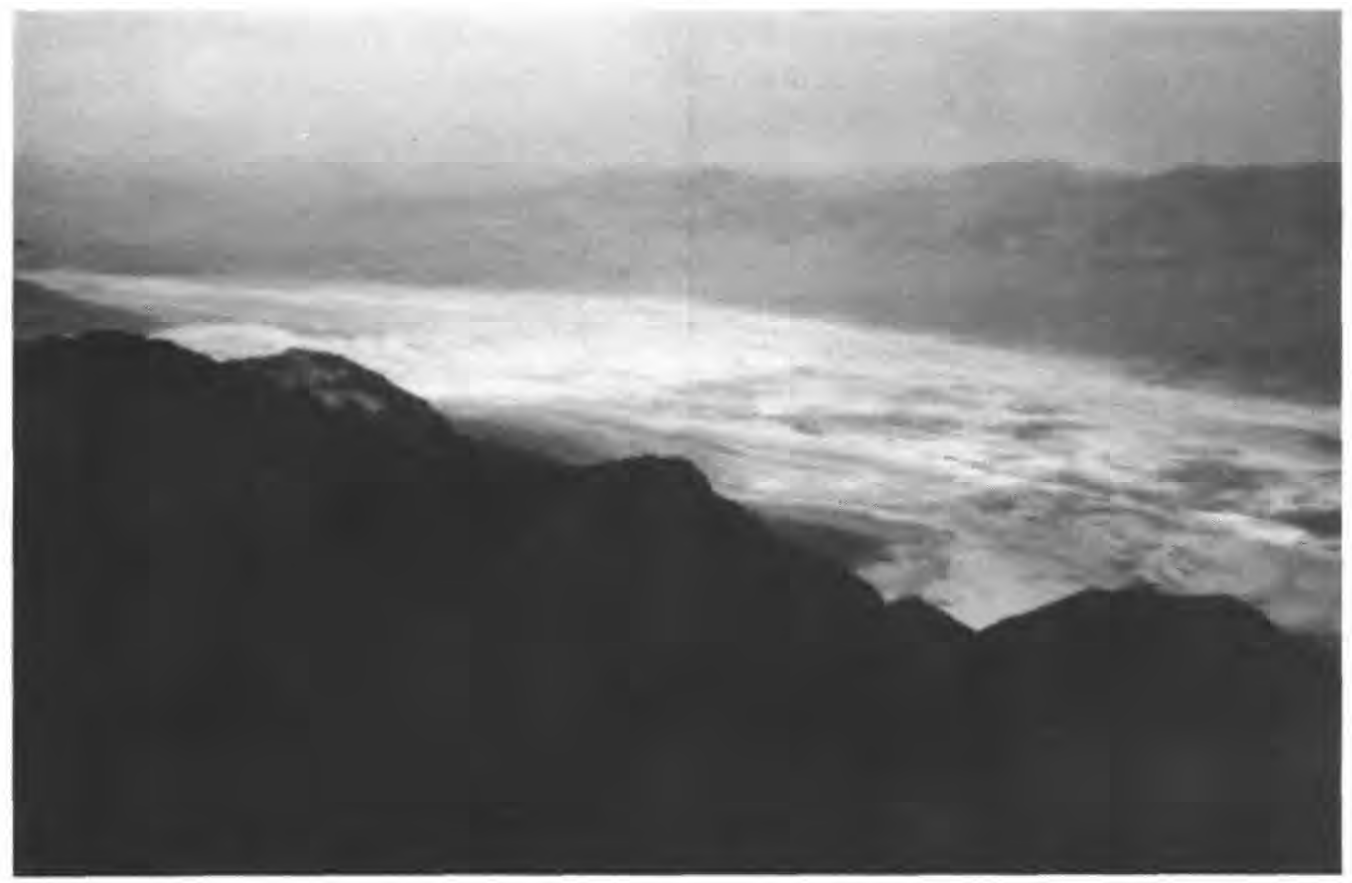

(B)

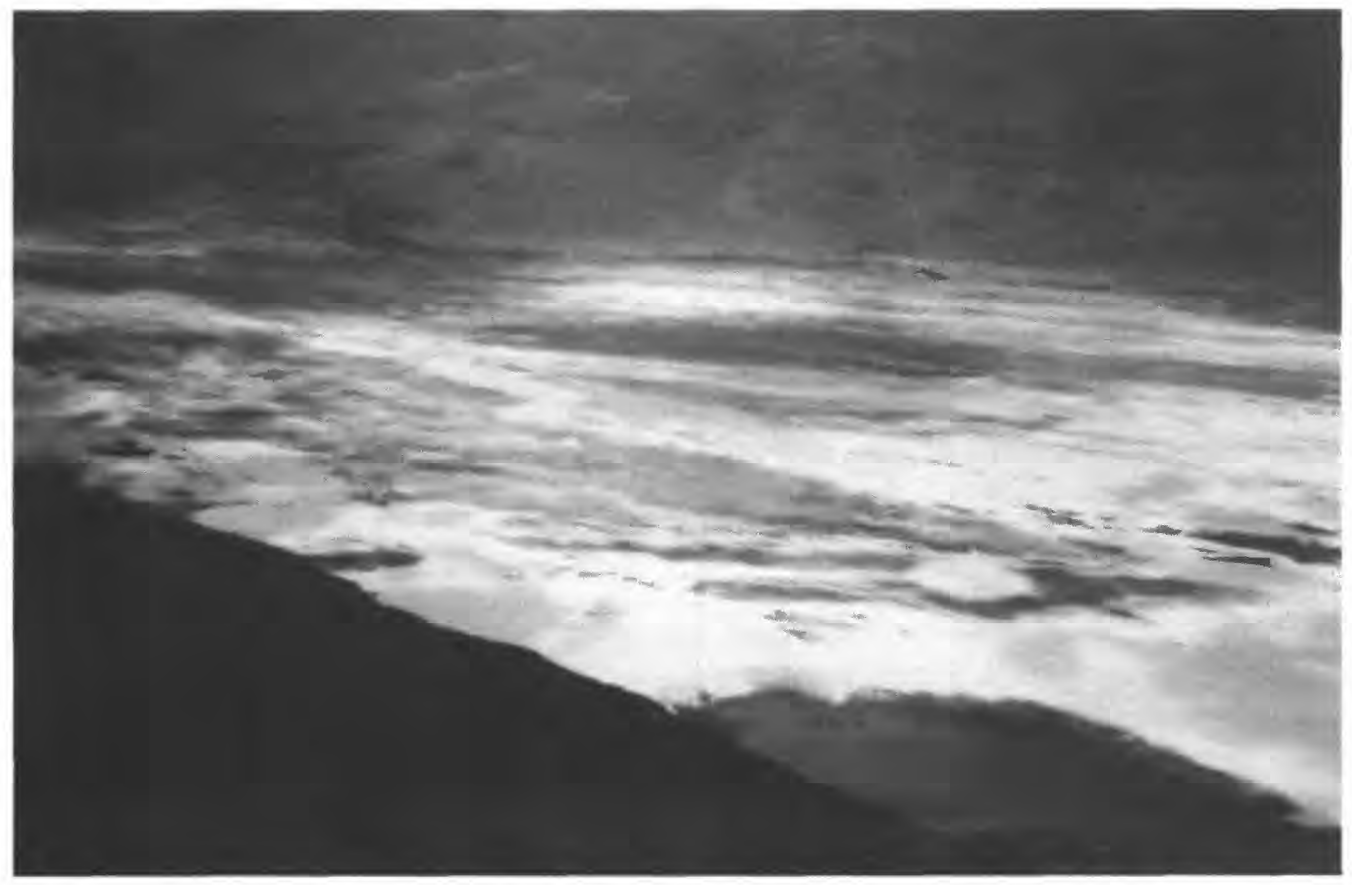

Figure 3. Oblique views of the alluvial braid plain at the terminus of the Amargosa River in southern Death Valley. (A) View to south-southwest; (B) view to southwest of the southern end of the Death Valley saltpan. A bathtub ring of saliferous ground, demarcating the high-water level of the late Holocene lake, borders alluvial fans in the foregrounds of both pictures. (Photographs taken from Dante's View, May 1993.) 
terminates in Cottonball Basin at the northern end of the Death Valley saltpan. Mesquite Flat consists of Pleistocene lacustrine sediments deposited by Lake Manly and younger, overlying aeolian sand dune and alluvial fan deposits. At the lowermost, southern end of Mesquite Flat, Salt Creek (north) flows in a poorly defined channel from beneath an expansive accumulation of aeolian sand in the Devil's Cornfield area of Death Valley. Farther downstream, near its terminus in Cottonball Basin, Salt Creek (north) flows in a narrow, steep-sided arroyo as a perennial stream issuing from a number of saline warm springs. Hunt (1966, p. A86) reported that Mesquite Flat was not submerged by the late Holocene lake and that the Devil's Cornfield dune sands post date the lake (that is, are less than about $2 \mathrm{ka}$ in age) because the dunes bury alluvium containing the diagnostic prehistoric " . . . Death Valley III [bow-andarrow] and Death Valley IV [pottery] occupation artifacts."

\section{Alluvial-Fan Drainage Basins}

The ephemeral streams that drain runoff from the large alluvial-fan aprons (bajadas) on opposite sides of Death Valley flow directly onto the saltpan (fig. 2). For this study, the many drainage basins of these west- and east-side bajadas were combined to form two hydrologic basin areas: Alluvial fans (west) and Alluvial fans (east). The cumulative areas of these west- and east-side alluvial fan drainage basins are 780 and $534 \mathrm{mi}^{2}$ (table 1). The stream channels of these drainage basins are generally steep and short, especially on the more tectonically active east side, and streamflow generally occurs only during heavy rainfall. On the west side of Death Valley, runoff from the higher Panamint Range also occurs as a result of spring snowmelt; and floods can result when warm late-winter and spring rains accelerate snowmelt. During severe storms, surface water and debris flows can travel the entire distance from fan head to toe, and coarse alluvium will be brought to rest unconformably on the valley floor. This unique stratigraphic relation of underlying lacustrine sediment and overlying alluvial deposits attests to the recent hydrologic changes (from lake to ephemeral streamflow) that have occurred in Death Valley during the latter half of the Holocene. For many of the larger alluvial-fan drainages, less intense rainfall and snowmelt runoff will percolate into the porous alluvium and resurface down-valley as seeps and springs. Thus, many of the springs on the west side of Death Valley emerge from the toes of fans near the periphery of the saltpan (Hunt, 1975).

\section{Death Valley Saltpan}

The Death Valley saltpan is a $223-\mathrm{mi}^{2}$, saline, playa lake flat that covers most of the floor of Death Valley (table 1, fig. 2). According to Hunt (1966, p. A79-A82) the evaporites composing the saltpan resulted from the " ... evaporation of ground water at a time when the water table was higher than it is now, and very probably at the time the Recent [late Holocene] lake filled the basin [2-5 ka]." Hunt (1966, p. A79-A82) anticipated that there was more moisture at that time and reported that the evaporites in the valley "... coincide with the shoreline of that [late Holocene] lake." Since the demise of this lake, a bathtub ring of saliferous ground marks the high-water level of the late Holocene lake on the surrounding alluvial fans (fig. 3B). The elevation of this feature indicates that the lake attained a depth of about 30 to $40 \mathrm{ft}$ and that post-late Holocene tectonism has tilted the valley eastward. As a result of this post-pluvial tectonism, the eastern shoreline is about $20 \mathrm{ft}$ lower than the western shoreline (Hunt, 1975, p. 15).

The color change that characterizes the bathtub ring in the valley is caused by light, unvarnished gravel and saline evaporite deposits that formed as the late Holocene lake repeatedly dried along its margin.

Below this level, the gravel composing the toes of the alluvial fans is washed clean within the shore zone of the former lake (fig. 1A). Above this level, the gravel is heavily coated with desert varnish. Additional evidence for the existence of a late Holocene lake in Death Valley is provided by erosional wave-cut shorelines (fig. 1B) and a distinctive slope change above and below the former shore zone. The downvalley slopes of alluvial fans above the shore zone range from about 2 to 6 degrees, whereas downvalley slopes of less than one degree occur on the alluvial fans that have been reworked by wave activity below the relic shore zone (Hunt, 1966, p. A82). 


\section{Climate}

The climate of the study area ranges from hyperarid at the lowest elevations of the watershed in Death Valley to alpine at the highest elevations in the Panamint Range. For much of the Death Valley watershed, arid to semiarid conditions prevail. Annual precipitation in Death Valley averages just 2.3 in. annually and is less than $8 \mathrm{in}$. for most of the watershed. Storms that bring relief from these hot, dry conditions in the watershed come from four distinct source areas (fig. 4). In late fall to early spring (November-April), referred to hereafter as the winter season, cold cyclonic fronts from the Northern Pacific Ocean move southeastward across the study area when the Great Basin High, a thermally induced and generally stagnant highpressure system, dissipates (Benson and Thompson, 1987). These slow-moving, winter storm fronts produce much of the region's annual precipitation and have the potential for prolonged, moderate- to highintensity rainfall and flooding. During the summer season (May to October in this report), precipitation over the study area is produced by convective thunderstorms that are spawn by the northward movement of warm moist air and hurricanes from the Gulf of California and, less frequently, by the northwestward movement of moisture from the Gulf of Mexico. These monsoon thunderstorms and tropical storms generally occur from July to August and from late August to September (fig. 4), and have the potential for disastrous flash floods in the watershed. The largest summer floods on the Amargosa River (1962-83), for example, were the result of a large, monsoon thunderstorm in August 1983 and storms from Hurricane Kathleen (Sept. 6-10, 1976) and Hurricane Liza (Sept. 25-Oct. 1, 1976) that brought intense rains and flooding to the deserts of the

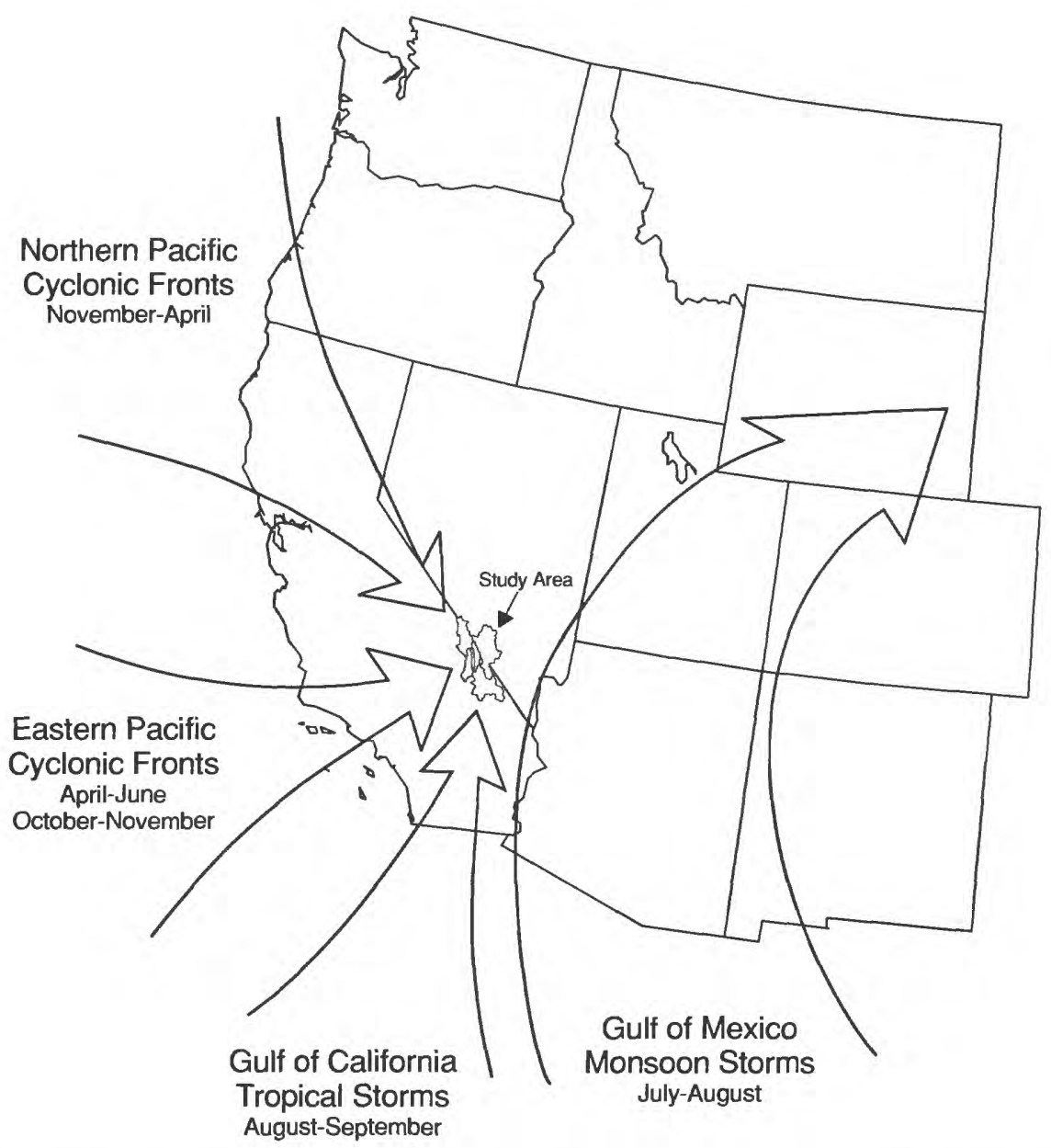

Figure 4. The predominant path of storms and the approximate period of their effect during an average year for the Death Valley watershed study area. 
Southwestern United States as they came ashore from the Gulf of California (National Oceanic and Atmospheric Administration, 1976). In terms of runoff, the August 1983 storm produced the largest volume of runoff and Hurricanes Kathleen and Liza produced the third and seventh largest volumes of runoff recorded for the Amargosa River at Tecopa, 1962-83. A peak discharge of $10,600 \mathrm{ft}^{3} / \mathrm{s}$ was recorded for the Amargosa River at Tecopa on August 18,1983, as a result of the August 1983 storm, and peak discharges of 725 , 1,060 , and $2,600 \mathrm{ft}^{3} / \mathrm{s}$ were recorded on September 11 , September 26, and October 2, 1976, as a result of the storms produced by Hurricanes Kathleen and Liza.

A fourth source of moisture for the watershed is the Eastern Pacific Ocean (fig. 4). Precipitation from these Eastern Pacific cyclonic fronts, known as Great Basin Lows or Tonopah Lows, generally occurs during the transition months (April-June and OctoberNovember) between winter and summer seasons but is usually quite meager because of the rain shadow effect of the Sierra Nevada and other prominent northtrending mountains west of Death Valley. Infrequently, however, large slow-moving tropical or subtropical warm fronts from the Eastern Pacific Ocean will track along this same path in the winter and deliver heavy rains to the region. One such storm occurred in late February 1969 and produced the second largest flood runoff recorded on the Amargosa River at Tecopa, 1962-83. This late-winter storm enveloped the deserts of southern California and Nevada with steady, moderate- to strong-intensity rains that produced severe floods and one of the largest lakes on record this century in Death Valley. The heaviest rains in the Death Valley watershed occurred during February 24-26, and a peak discharge of $5,000 \mathrm{ft}^{3} / \mathrm{s}$ was recorded on the Amargosa River at Tecopa on February 25, 1969. One month earlier, a similar tropical storm from the Eastern Pacific Ocean moved across coastal southern California and caused widespread flooding and mud slides (National Oceanic and Atmospheric Administration, 1969). This storm went generally north of the Death Valley watershed effecting only the northernmost upper Amargosa River Basin.

The annual distribution of precipitation over the Death Valley watershed is exemplified by the 1962-83 hydrologic record of the Amargosa River at Tecopa, California. The maximum monthly runoff record of the Amargosa River (1962-83) indicates that a bimodal distribution has existed with noticeable breaks between winter and summer seasons in May-July and OctoberNovember (fig. 5). For the 22-yr period, the highest

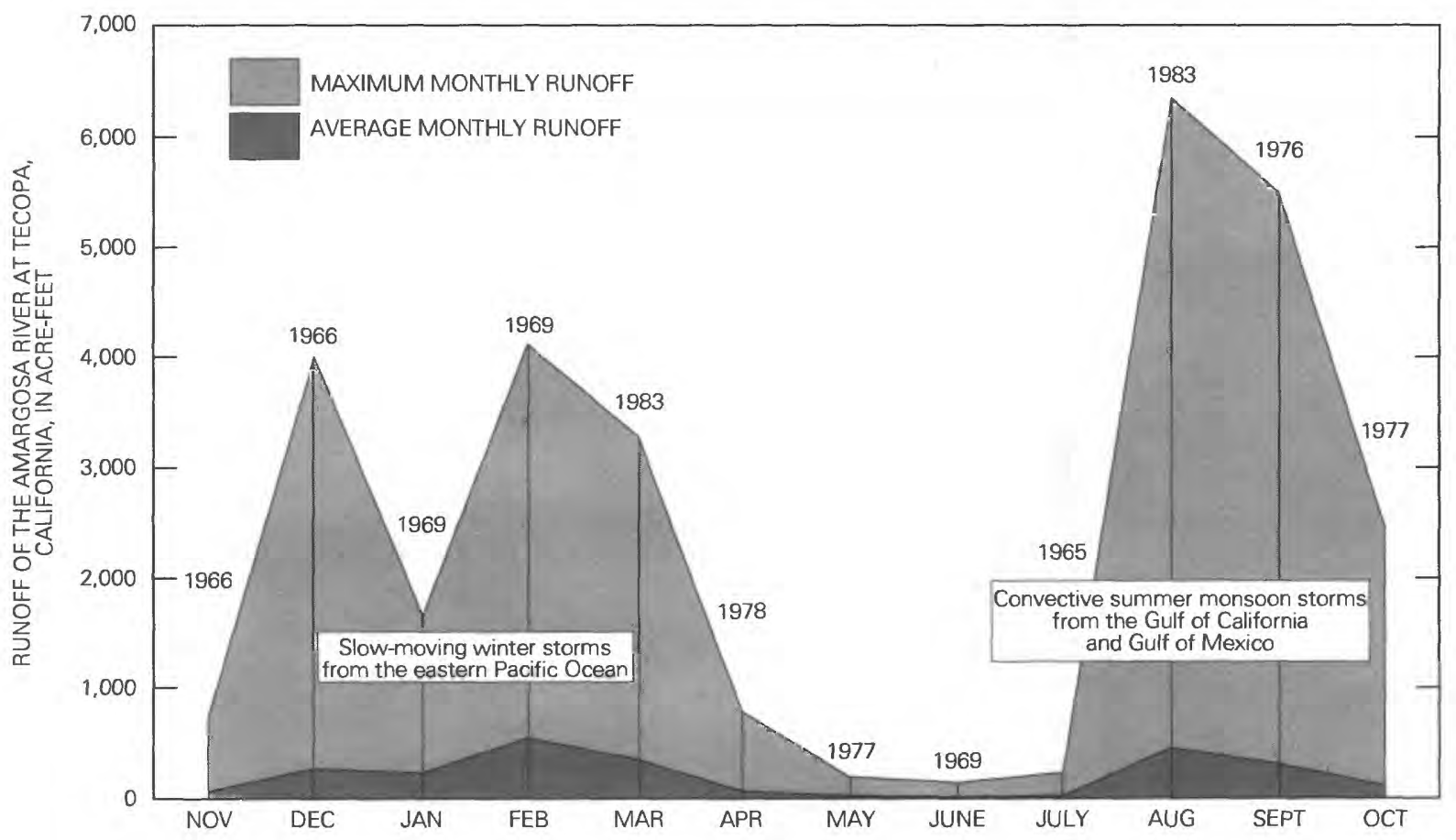

Figure 5. Maximum and average monthly runoff and the year that the maximum monthly runoff occurred from the upper Amargosa River Basin, as recorded on the Amargosa River at Tecopa, California, 1962-83. In this report, the winter season is November-April, and the summer season is May-October. 
monthly runoff occurred in August and September as the result of the August 1983 monsoon thunderstorm and the September 1976 tropical hurricanes. In winter, maximum monthly runoff has been generally lower than for summer months, however, because of the more frequent and prolonged nature of the slow-moving winter storms in the area, cumulative winter runoff has been generally higher than summer runoff. This seasonal distinction is important because ephemeral lakes that have formed in the closed-basin Death Valley watershed have reportedly been produced by prolonged, above-normal runoff from frequent storms during a single winter season.

\section{MODERN SURFACE-WATER HYDROLOGY}

The periodic existence of modern ephemeral lakes in Death Valley and the prior existence of a large, perennial lake in Death Valley during the late Holocene (Hunt, 1966; 1975) presents an important regional hydroclimatic problem. First, while the late Holocene lake may have been supported, in part, by a higher ground-water table (for example, Hunt, 1966, p. A82; Winograd and Szabo, 1985, p. 1), modern ephemeral lakes in Death Valley are produced chiefly by surfacewater runoff and direct precipitation. Second, because no external sources of surface water have been available since the late Pleistocene, the water for both types of lakes must have come from sources acting within the confines of the Death Valley watershed.

A regional precipitation-runoff analysis of the Death Valley watershed was conducted to evaluate the contributions of lake water from climatic and hydrologic sources within the Death Valley watershed. Precipitation and streamflow data of the upper Amargosa River Basin were analyzed to establish the quantity of surface-water runoff contributed by this basin to modern lakes in Death Valley and to estimate the potential quantities of surface-water runoff that may be contributed by ungaged drainage basins in the watershed. These hydroclimatic parameters were then used to evaluate the hydrologic budget of the watershed during the winter 1969 lake period and to estimate the regional hydroclimatic changes needed to produce and maintain a perennial lake in Death Valley during the late Holocene.

\section{Precipitation-Runoff Relations}

Precipitation-runoff analyses of individual storms and seasonal conditions were based on daily, monthly, and seasonal precipitation amounts recorded at National Oceanic and Atmospheric Administration (NOAA) and Nevada Test Site (NTS) weather stations in southern Nevada and southeastern California; and on peak and daily mean discharge streamflow data for the Amargosa River at Tecopa, California (1962-83), and Beatty, Nevada (1963-68). Daily streamflow data for the Amargosa River were retrieved from the U.S. Geological Survey's Water Data and Storage Retrieval Information System (WATSTORE). Although the Amargosa River streamflow record at Tecopa ended with the destruction of the gaging station ${ }^{1}$ by a severe flood on August 18, 1983, the 22 years (1962-83) of data provide a relatively long and useful record of modern surface-water runoff. A comparison of these streamflow data with recorded regional precipitation data for the upper Amargosa River Basin establishes precipitation-runoff relations for this part of the Death Valley watershed.

Storm and seasonal precipitation-runoff relations were assessed using estimated precipitation volumes over the upper Amargosa River Basin and cumulative, daily mean-streamflow volumes recorded for the same period on the Amargosa River at Tecopa, California. A computer simulation model, kriging, was used to interpolate the distribution and estimate the volume of precipitation from monthly and seasonal periods over the upper Amargosa River Basin and other drainage basins of the Death Valley watershed (fig. 2) from selected NOAA and NTS weather stations (fig. 6; table 2). Although kriging offers an effective method for measuring the distribution and uniform depth of rainfall over a drainage basin from irregularly spaced weather stations (Fetter, 1988; Abtew and others, 1993), this geostatistical method does not directly account for variations in rainfall that may be caused by the orographic effect of mountains or to unusually large rainfall amounts that may fall over a single weather station during a small, localized thunderstorm or cloud burst (Michaud and Sorooshian, 1994). Also, the scarcity of weather stations in this arid region (fig. 6) required interpolation over large distances, and thus increased

1 The gaging station at Tecopa, California, was eventually reinstalled by the U.S. Geological Survey, Nevada, but not until late 1991 (Tom Kane, personal commun., 1993). 


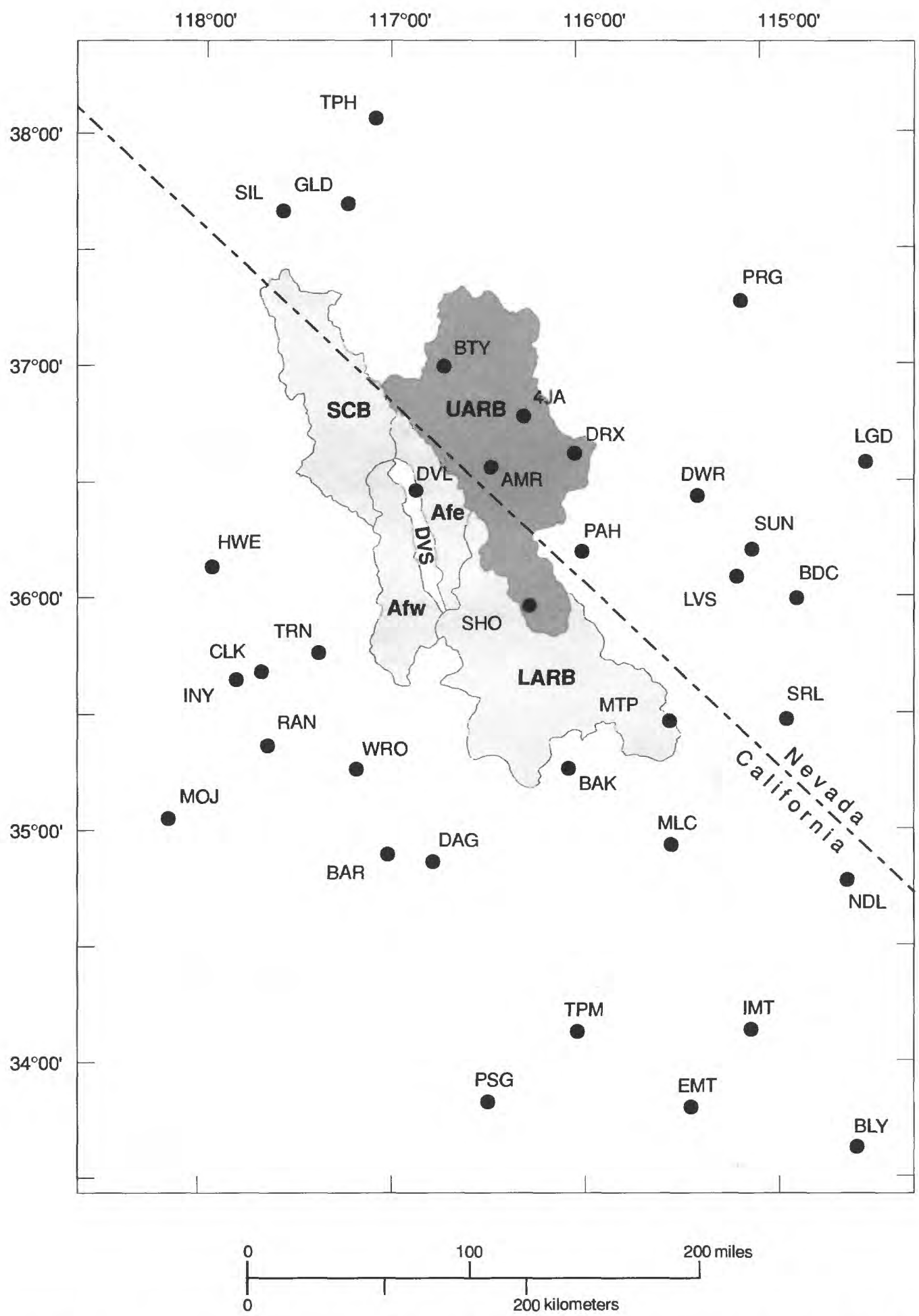

Figure 6. The locations of National Oceanic and Atmospheric Administration and Nevada Test Site weather stations in Nevada and California that were used to interpolate the monthly and seasonal distributions of precipitation over the Death Valley watershed. (See table 2 for letter codes.) 
Table 2. Weather stations in southern Nevada and southeastern California used for precipitation mapping and analysis of the Death Valley watershed

[Annual rainfall is average for period of record indicated; deg, degrees; min, minutes; $\mathrm{ft}$, feet; in., inches]

\begin{tabular}{|c|c|c|c|c|c|c|}
\hline \multirow[b]{2}{*}{ Station name } & \multicolumn{3}{|c|}{ Figure 6} & \multirow{2}{*}{$\begin{array}{l}\text { Station } \\
\text { elevation } \\
\text { (ft) }\end{array}$} & \multirow{2}{*}{$\begin{array}{l}\text { Annual } \\
\text { rainfall } \\
\text { (in.) }\end{array}$} & \multirow[b]{2}{*}{$\begin{array}{l}\text { Period of } \\
\text { record }\end{array}$} \\
\hline & $\begin{array}{l}\text { Map } \\
\text { code }\end{array}$ & $\begin{array}{c}\text { Latitude } \\
\text { (deg min) }\end{array}$ & $\begin{array}{l}\text { Longitude } \\
\text { (deg } \mathrm{min} \text { ) }\end{array}$ & & & \\
\hline \multicolumn{7}{|c|}{ Southern Nevada } \\
\hline Amargosa Farms & AMR & $3634 \mathrm{~N}$ & $11628 \mathrm{~W}$ & 2,450 & 4.66 & $1965-93$ \\
\hline Beatty & BTY & $3700 \mathrm{~N}$ & $11643 \mathrm{~W}$ & 3,550 & 4.03 & $1948-72$ \\
\hline Boulder City & BDC & $3559 \mathrm{~N}$ & $11451 \mathrm{~W}$ & 2,525 & 5.71 & $1931-93$ \\
\hline Desert National Wildlife Range & DWR & $3626 \mathrm{~N}$ & $11522 \mathrm{~W}$ & 2,920 & 4.33 & $1948-93$ \\
\hline Goldfield & GLD & $3742 \mathrm{~N}$ & $11714 \mathrm{~W}$ & 5,690 & 6.50 & $1948-93$ \\
\hline Las Vegas Airport & LVS & $3605 \mathrm{~N}$ & $11510 \mathrm{~W}$ & 2,162 & 4.17 & 1949-93 \\
\hline Logandale & LGD & $3634 \mathrm{~N}$ & $11428 \mathrm{~W}$ & 1,320 & 5.31 & $1968-92$ \\
\hline Nevada Test Site (4JA) & $4 J \mathrm{~A}$ & $3647 \mathrm{~N}$ & $11617 \mathrm{~W}$ & 3,422 & 4.52 & $1962-92$ \\
\hline Nevada Test Site (Desert Rock) & DRX & $3637 \mathrm{~N}$ & $11601 \mathrm{~W}$ & 3,298 & 6.45 & 1979-91 \\
\hline Pahranagat & PRG & $3716 \mathrm{~N}$ & $11507 \mathrm{~W}$ & 3,400 & 6.62 & $1964-93$ \\
\hline Pahrump & PAH & $3612 \mathrm{~N}$ & $11559 \mathrm{~W}$ & 2,670 & 4.79 & $1948-93$ \\
\hline Searchlight & SRL & $3528 \mathrm{~N}$ & $11455 \mathrm{~W}$ & 3,540 & 7.53 & 1948-93 \\
\hline Silverpeak & SIL & $3740 \mathrm{~N}$ & $11735 \mathrm{~W}$ & 4,263 & 4.71 & $1967-93$ \\
\hline Sunrise Manor & SUN & $3612 \mathrm{~N}$ & $11505 \mathrm{~W}$ & 1,820 & 4.48 & $1961-89$ \\
\hline Tonopah & TPH & $3804 \mathrm{~N}$ & $11705 \mathrm{~W}$ & 5,426 & 5.35 & 1954-93 \\
\hline \multicolumn{7}{|c|}{ Southeastern California } \\
\hline Baker & BAK & $3516 \mathrm{~N}$ & $11604 \mathrm{~W}$ & 940 & 4.03 & $1971-90$ \\
\hline Barstow Fire Station & BAR & $3454 \mathrm{~N}$ & $11701 \mathrm{~W}$ & 2,320 & 4.30 & $1913-80$ \\
\hline Blythe & BLY & $3337 \mathrm{~N}$ & $11436 \mathrm{~W}$ & 268 & 3.78 & $1931-93$ \\
\hline Daggett Airport & DAG & $3452 \mathrm{~N}$ & $11647 \mathrm{~W}$ & 1,922 & 3.99 & $1948-93$ \\
\hline Death Valley & DVL & $3628 \mathrm{~N}$ & $11652 \mathrm{~W}$ & -194 & 2.32 & $1961-93$ \\
\hline Eagle Mtn & EMT & $3348 \mathrm{~N}$ & $11527 \mathrm{~W}$ & 973 & 3.63 & $1948-93$ \\
\hline Haiwee & HWE & $3608 \mathrm{~N}$ & $11757 \mathrm{~W}$ & 3,825 & 6.70 & $1948-93$ \\
\hline Inyokern & INY & $3539 \mathrm{~N}$ & $11749 \mathrm{~W}$ & 2,440 & 3.94 & $1948-93$ \\
\hline Inyokern (China Lake) & CLK & $3541 \mathrm{~N}$ & $11741 \mathrm{~W}$ & 2,220 & 3.13 & 1948-78 \\
\hline Iron Mtn & IMT & $3408 \mathrm{~N}$ & $11508 \mathrm{~W}$ & 922 & 3.47 & $1948-93$ \\
\hline Mitchell Caverns & MLC & $3456 \mathrm{~N}$ & $11532 \mathrm{~W}$ & 4,350 & 9.90 & $1958-93$ \\
\hline Mojave & MOJ & $3503 \mathrm{~N}$ & $11810 \mathrm{~W}$ & 2,735 & 5.34 & $1948-93$ \\
\hline Mountain Pass & MTP & $3528 \mathrm{~N}$ & $11532 \mathrm{~W}$ & 4,730 & 8.61 & $1955-93$ \\
\hline Needles Airport & NDL & $3446 \mathrm{~N}$ & $11437 \mathrm{~W}$ & 914 & 4.66 & $1948-93$ \\
\hline Palm Springs & PSG & $3350 \mathrm{~N}$ & $11630 \mathrm{~W}$ & 425 & 5.62 & $1927-93$ \\
\hline Randsburg & RAN & $3522 \mathrm{~N}$ & $11739 \mathrm{~W}$ & 3,570 & 5.94 & $1948-93$ \\
\hline Shoshone & SHO & $3558 \mathrm{~N}$ & $11616 \mathrm{~W}$ & 1,570 & 4.77 & $1972-93$ \\
\hline Trona & TRN & $3546 \mathrm{~N}$ & $11723 \mathrm{~W}$ & 1,695 & 3.73 & 1948-93 \\
\hline Twentynine Palms & TPM & $3408 \mathrm{~N}$ & $11602 \mathrm{~W}$ & 1,975 & 4.12 & $1948-93$ \\
\hline Wildrose Ranger Station & WRO & $3616 \mathrm{~N}$ & $11711 \mathrm{~W}$ & 4,100 & 7.05 & $1969-93$ \\
\hline
\end{tabular}


the potential for estimation error. For these reasons, the areal distributions and volumes of precipitation that are given in this report for individual storms and monthly and seasonal periods should be considered as estimates of the actual rainfall amounts that were received by basins of the Death Valley watershed.

The precipitation-runoff record of the upper Amargosa River Basin exemplifies the hydroclimatology of ephemeral streamflow in the Death Valley watershed. The temporal (1962-83) trends of seasonal precipitation over the upper Amargosa River Basin and seasonal runoff of the Amargosa River at Tecopa (figs. 7 and 8 ) indicate that (1) winters are generally wetter than summers, (2) there is a close correspondence between seasonal precipitation and runoff, and (3) above-normal precipitation and runoff have generally occurred during ENSO years. For southeastern California, Schonher and Nicholson (1989, p. 1263) indicated that 7 to 8 of the 10 wettest years (1951-78 and 1982-83) were ENSO years, and that the probabil- ity of dry conditions occurring during an ENSO year were from 0 to 18 percent. The ENSO years identified by Schonher and Nicholson (1989, p. 1260) include those years classified as ENSO years by at least two authors (1951-52, 1953-54, 1957-58, 1963-64, 1965 $66,1968-69,1969-70,1972-73,1976-77,1977-78$, and 1982-83). The ENSO years that occurred between 1962 and 1983 are shown in figures 7 and 8 with ENSO years $(1965,1969,1972,1976$ and 1982) identified by Ropelewski and Halpert (1986). For the Death Valley watershed, a period of above-normal winter precipitation-runoff, centered on the winter of 1969 , coincides with the 1968-69 and 1969-70 ENSO years identified by Schonher and Nicholson (1989) and the 1969 ENSO year identified by Ropelewski and Halpert (1986) (figs. 7 and 8). The effects of ENSO on the Death Valley watershed were recently observed by the author in 1992 and 1993 when an unusually persistent El Nino induced frequent and prolonged winter rains, flooding, and the formation of late winter, ephemeral lakes in

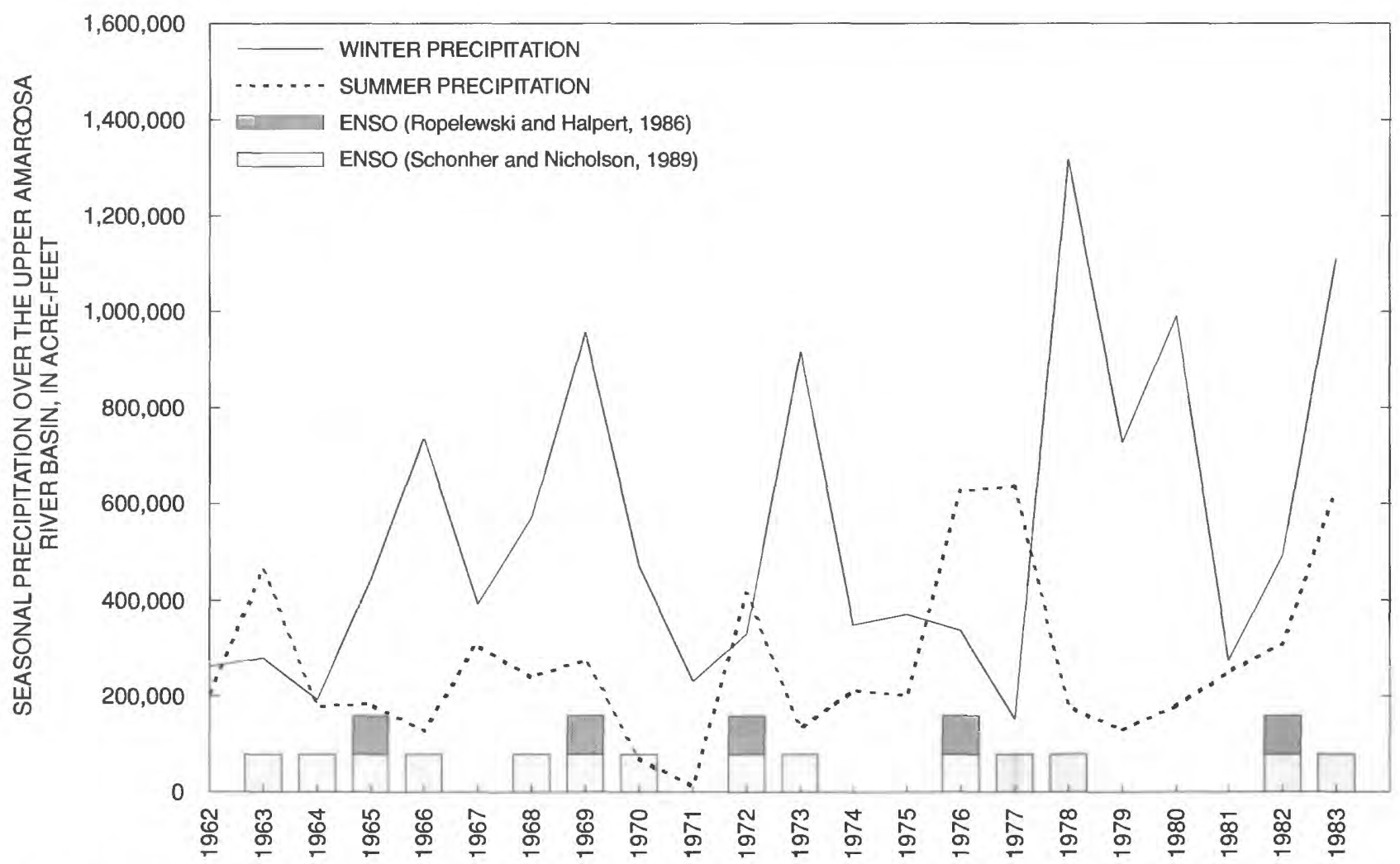

Figure 7. Estimated cumulative precipitation during winter (November-April) and summer (May-October) seasons over the upper Amargosa River Basin, 1962-83, and the occurrences of El Nino-Southern Oscillation (as identified by Ropelewski and Halpert, 1986; Schonher and Nicholson, 1989). 


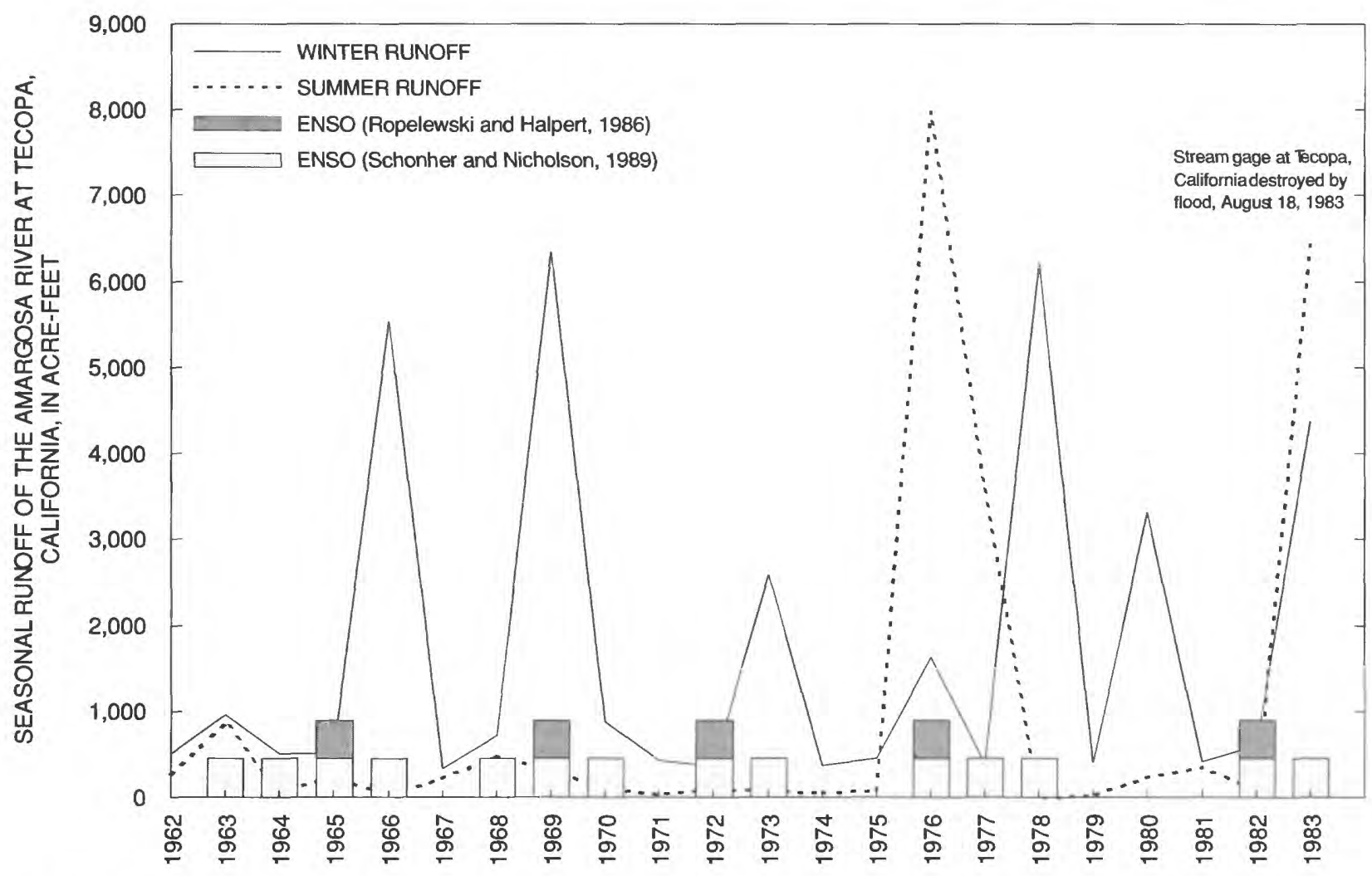

Figure 8. Seasonal runoff during winter (November-April) and summer (May-October) seasons from the upper Amargosa River Basin, as recorded on the Amargosa River at Tecopa, California, 1962-83, and the occurrences of El Nino-Southern Oscillation (as identified by Ropelewski and Halpert, 1986; Schonher and Nicholson,1989).

Death Valley during both years. The 1993 lake in Death Valley is shown in figure 1.

In addition to the ENSO-related trends illustrated in figures 7 and 8, the seasonal precipitation-runoff record of the upper Amargosa River Basin indicates some important hydroclimatic conditions of ephemeral streamflow in the watershed. A comparison of the estimated volume of precipitation over the upper Amargosa River Basin and the volume of runoff recorded on the Amargosa River at Tecopa during the winter and summer seasons (fig. 9) indicates that winter storms tend to produce larger precipitation amounts than summer storms, but that larger runoff volumes and floods may be produced by summer storms of less total rainfall. For rainfall volumes greater than about 400,000 acre- $f t$ over the basin, summer runoff has been higher than winter runoff, whereas winter storms that produce less than about 400,000 acre-ft of rainfall have generally yielded larger runoff volumes on the Amargosa River than summer storms of the same magnitude (fig. 9). These precipitation-runoff relations may be caused by (1) seasonal differences in the intensity and regional extent of winter versus summer storms, (2) seasonal differences in evapotranspiration, and (3) seasonal differences in the infiltration rate and water-holding capacity of the basin's surface material. The slopes of the seasonal curves shown in figure 9 also indicate that summer storms over the basin tend to produce more variable runoff then winter storms, probably due to the more localized nature of a typical summer thunderstorm, although other related factors, such as storm duration, rainfall intensity, infiltration, and evapotranspiration are undoubtedly involved. The higher runoff-to-rainfall ratio of winter versus summer storms of less than about 400,000 acre- $\mathrm{ft}$ of rainfall, for example, suggests that the characteristically low evapotranspiration rate of the cooler winter season may be a less dominant factor in controlling runoff than during the hot, dry summer season. 


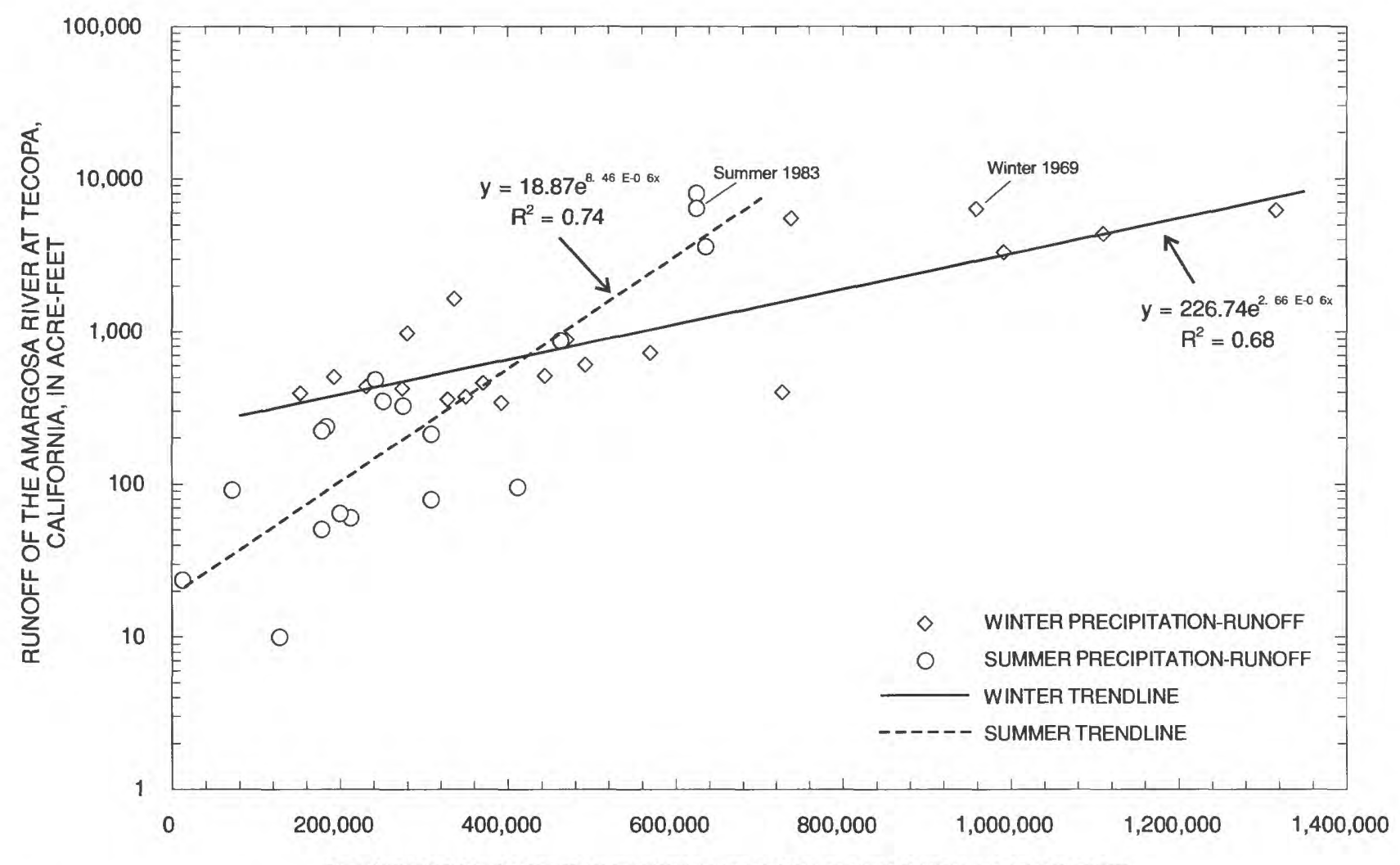

PRECIPITATION OVER THE UPPER AMARGOSA RIVER BASIN, IN ACRE-FEET

Figure 9. Seasonal precipitation runoff and linear trends for winter (November-April) and summer (May-October) season storms over the upper Amargosa River Basin, 1962-83.

\section{Storms and Floods}

Ephemeral streams of the Death Valley watershed flow only in response to moderate to heavy precipitation that can occur in isolated areas or over large segments of the watershed. During low-intensity storms (for example, storms that produce less than about $0.50-0.75$ in. of rainfall on average over the upper Amargosa River Basin), little or no runoff will occur on the Amargosa River at Tecopa due to high evapotranspiration and infiltration rates in the basin. On the other hand, high-intensity storms that produce more than about 1 in. of rainfall on average over the basin can produce substantial runoff and flash floods.

Between 1962 and 1983, a number of storms over the upper Amargosa River Basin produced measurable runoff and flooding on the Amargosa River at Tecopa. Of the 10 largest runoff-volume floods recorded at Tecopa, 5 were caused by winter (December-February) storms, 2 were caused by summer (August) thunderstorms, and 3 were caused by late-summer (September) tropical hurricanes (table 3). A discussion of the three largest storms (table 3 ) will help to characterize the types of seasonal storms that have produced the largest floods and surface-water runoff in the Death Valley watershed.

The largest flood on record for the watershed, in terms of both storm runoff and peak discharge (table 3 ), occurred in the summer on August 18, 1983. On this date, a flood having a peak discharge of $10,600 \mathrm{ft}^{3} / \mathrm{s}$ moved down the Amargosa River and destroyed the gaging station at Tecopa. This flood was caused by an intense, slow-moving storm that came into the area from the south after 3 days of unusually wet weather that was triggered by large amounts of atmospheric moisture from tropical storms to the south and southeast (National Oceanic and Atmospheric Administration, 1983). Within a matter of hours, beginning late on August 17 (fig. 10), heavy rains over the upper Amargosa River Basin quickly overcame the infiltration rate and capacity of the basin's surface material and a large 
Table 3. Ten largest storm runoff periods recorded for the Amargosa River at Tecopa, Califomia, 1962-83, ranked in order of decreasing volume

[acre-ft, acre-feet; $\mathrm{ft}^{3} / \mathrm{s}$, cubic feet per second]

\begin{tabular}{|c|c|c|c|c|c|}
\hline \multicolumn{4}{|c|}{ Storm runoff period } & \multicolumn{2}{|c|}{ Peak discharge } \\
\hline Start date & End date & $\begin{array}{c}\text { Duration } \\
\text { (days) }\end{array}$ & $\begin{array}{l}\text { Volume } \\
\text { (acre-ft) }\end{array}$ & Date & $\begin{array}{c}\text { Discharge } \\
\left(\mathrm{ft}^{3} / \mathrm{s}\right)\end{array}$ \\
\hline Aug. 15, 1983 & Sept. 9,1983 & 25 & 6,322 & Aug. 18, 1983 & 10,600 \\
\hline Feb. 24, 1969 & March 8, 1969 & 12 & 3,878 & Feb. 26, 1969 & 5,000 \\
\hline Sept. 9, 1976 & Sept. 19, 1976 & 10 & 3,716 & Sept. 11, 1976 & 725 \\
\hline Aug. 16, 1977 & Aug. 25, 1977 & 9 & 3,374 & Aug. 17, 1977 & 1,680 \\
\hline Dec. 8, 1965 & Dec. 24, 1965 & 16 & 3,307 & Dec. 11, 1965 & 2,419 \\
\hline Feb. 23, 1983 & March 16, 1983 & 21 & 3,273 & March 3, 1983 & 1,260 \\
\hline Sept. 30, 1976 & Oct. 10, 1976 & 10 & 2,283 & Oct. 2, 1976 & 2,600 \\
\hline Sept. 23, 1976 & Sept. 30, 1976 & 7 & 1,719 & Sept. 26, 1976 & 1,060 \\
\hline Feb. 12, 1980 & March 1, 1980 & 18 & 1,675 & Feb. 17, 1980 & 686 \\
\hline Jan. 17, 1969 & Feb. 4, 1969 & 18 & 1,468 & Jan. 25,1969 & 1,705 \\
\hline
\end{tabular}

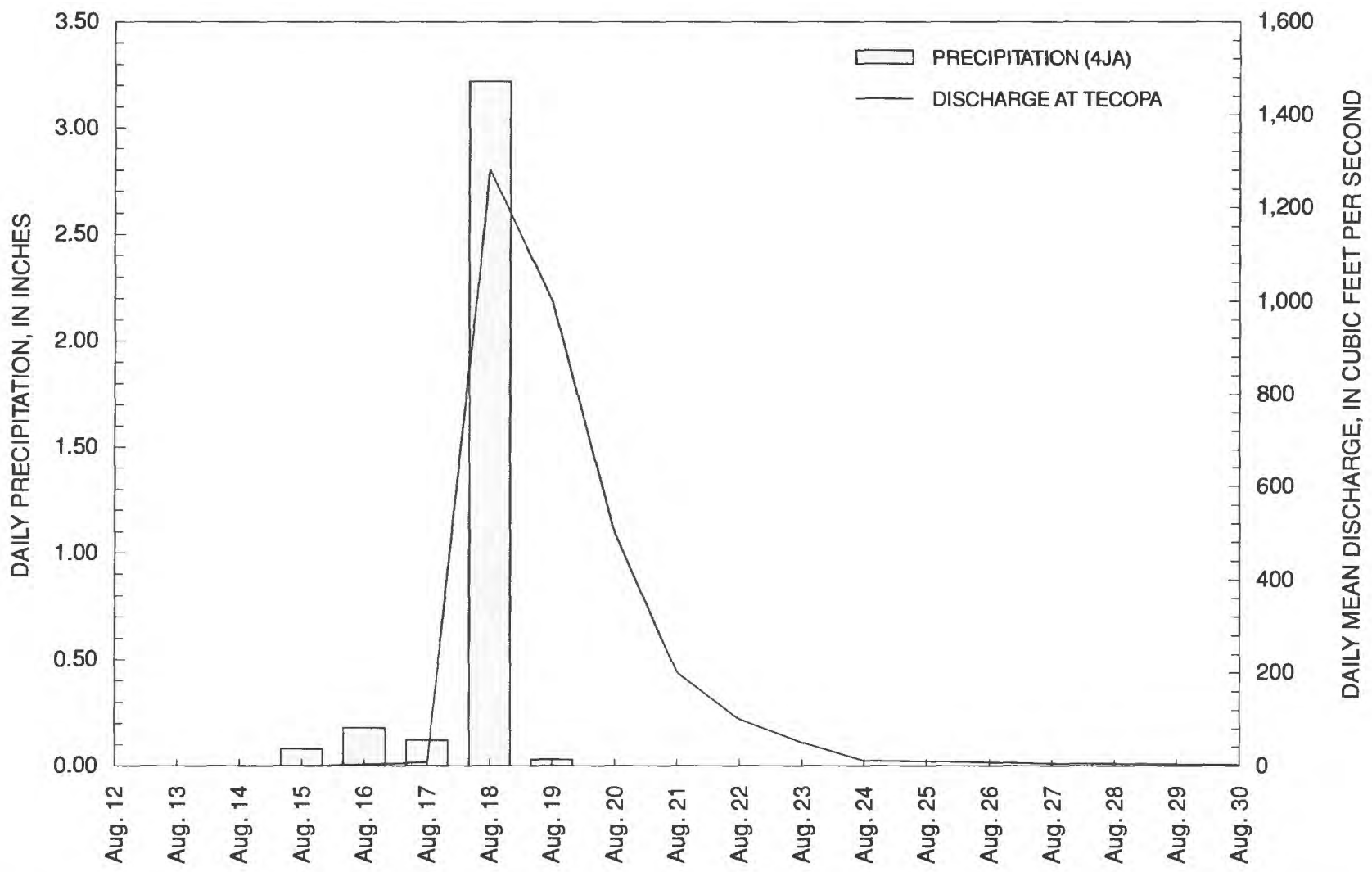

Figure 10. Hydrograph of the Amargosa River, August 12-30,1983, showing daily rainfall at Nevada Test Site weather station 4JA, in inches, and daily mean discharge at Tecopa, Califomia, in cubic feet per second. 
flood swept down the Amargosa River. The upper Amargosa River Basin received from 3 to 5 in. of rain from the storm during the week of August 14-20, 1983; an amount that was more than 2 in. above normal for the period. The heaviest rainfall from the storm occurred in the vicinity of the Nevada Test Site near weather station $4 \mathrm{JA}$ and along the south face of the Providence and New York Mountains near Mitchell Caverns (MLC), southeast of Baker (BAK), California (figs. 6 and 11). August 1983 rainfall totals recorded at NOAA weather stations Amargosa Desert (AMR), Shoshone (SHO), and Death Valley (DVL) were respectively $4.0 \mathrm{in}$., $2.3 \mathrm{in}$., and $1.1 \mathrm{in}$.; amounts that were 3.4 in., $1.8 \mathrm{in}$., and $1.0 \mathrm{in}$. above normal for the month (figs. 6 and 11).

An important hydrologic characteristic of the August 1983 storm was its intense rains. The storm produced the largest runoff $(6,320$ acre-ft), the largest peak discharge $\left(10,600 \mathrm{ft}^{3} / \mathrm{s}\right)$, and the largest runoffto-rainfall ratio (about 1.3 percent) of all the stormrunoff periods recorded between 1962 and 1983 on the Amargosa River at Tecopa, California (table 4). On the basis of the Amargosa River flood record at Tecopa, this storm has a recurrence interval of 23 years.

The second largest flood on record for the watershed, in terms of both runoff and peak discharge (table 3), occurred in winter on February 26, 1969. This flood was caused by two slow-moving Pacific Ocean storm fronts that moved into the area from the southwest and west. Unlike the more intense storm that produced the August 1983 flood, the 1969 flood was caused by prolonged, steady rainfall that started on February 18 and intensified on February 24 and 25 (fig. 12). The heaviest rains over the upper Amargosa River Basin occurred on February 24, 1969, near NTS weather station 4JA (figs. 6 and 13). This 11.5-yearrecurrence-interval flood had a peak discharge of $5,000 \mathrm{ft}^{3} / \mathrm{s}$ on February 26 and a total runoff volume from the upper Amargosa River Basin of 3,878 acre-ft (table 4). Although heavy rains fell over most of the Death Valley watershed (fig. 13), the upper Amargosa River Basin received the greatest total rainfall in the watershed (an estimated 2.5-3.5 in.) because of its position relative to the southwest-to-northeast and west-to-east tracks of the two storm fronts and its distance from the rainshadow of the Panamint Range west of Death Valley (fig. 2). For the 2-month period shown in figure 13, the heaviest rains (more than 5.0 in.) fell over the Mojave Desert west-southwest of the study area near NOAA weather stations at Randsburg (RAN) and Wildrose Ranger Station (WRO), California (figs. 6 and 13).

An important hydrologic characteristic of the February-March 1969 winter storms is that while these storms produced the second largest runoff and peak discharge flood (tables 3 and 4), surface-water runoff was only 0.8 percent of precipitation (that is, slightly more than half that of the more intense August 1983 storm). The dissimilarity in rainfall distribution (figs. 11 and 13) and runoff-to-rainfall ratio of these two largest storm-runoff periods on the Amargosa River (August 1983 and February-March 1969) further demonstrates the inherent seasonal nature of summer versus winter precipitation-runoff conditions for the Death Valley watershed as previously shown in figure 9.

The third largest storm-runoff period on record for the Amargosa River at Tecopa (table 3) occurred in late summer, September 9-19, 1976, as a result of moderate-to-heavy rainfall from Hurricane Kathleen. This slow-moving tropical storm moved into the study area from the south-southwest across northern Baja California (fig. 14) and produced heavy, widespread rains and flash floods in southeastern California and southern Nevada (National Oceanic and Atmospheric Administration, 1976; Smith, 1986). After a week of measurable rainfall over the upper Amargosa River Basin, that began on September 4, a flood moved down the Amargosa River and reached a peak discharge of $725 \mathrm{ft}^{3} / \mathrm{s}$ on September 11 at Tecopa, California (fig. 15). Although this flood had a relatively low peak discharge, total runoff on the Amargosa River from Hurricane Kathleen was 3,720 acre-ft, the third largest runoff volume recorded at Tecopa (table 3 ).

Following the passage of Hurricane Kathleen, two short-lived streamflow events occurred in late September and early October 1976 in response to Hurricane Liza (fig. 15). Although the storms spawn by Hurricane Liza produced floods on the Amargosa River having peak discharges of 1,060 and $2,600 \mathrm{ft}^{3} / \mathrm{s}$ on September 26 and October 2, 1976, the volumes of streamflow runoff from these storms was notably lower than that produced by Hurricane Kathleen (table 3 ). This relation further shows that the highest peakdischarge streamflows on the Amargosa River are produced by intense, short-duration summer thunderstorms (for example, the August 1983 storm) and cloud bursts, whereas the largest surface-water runoff is 

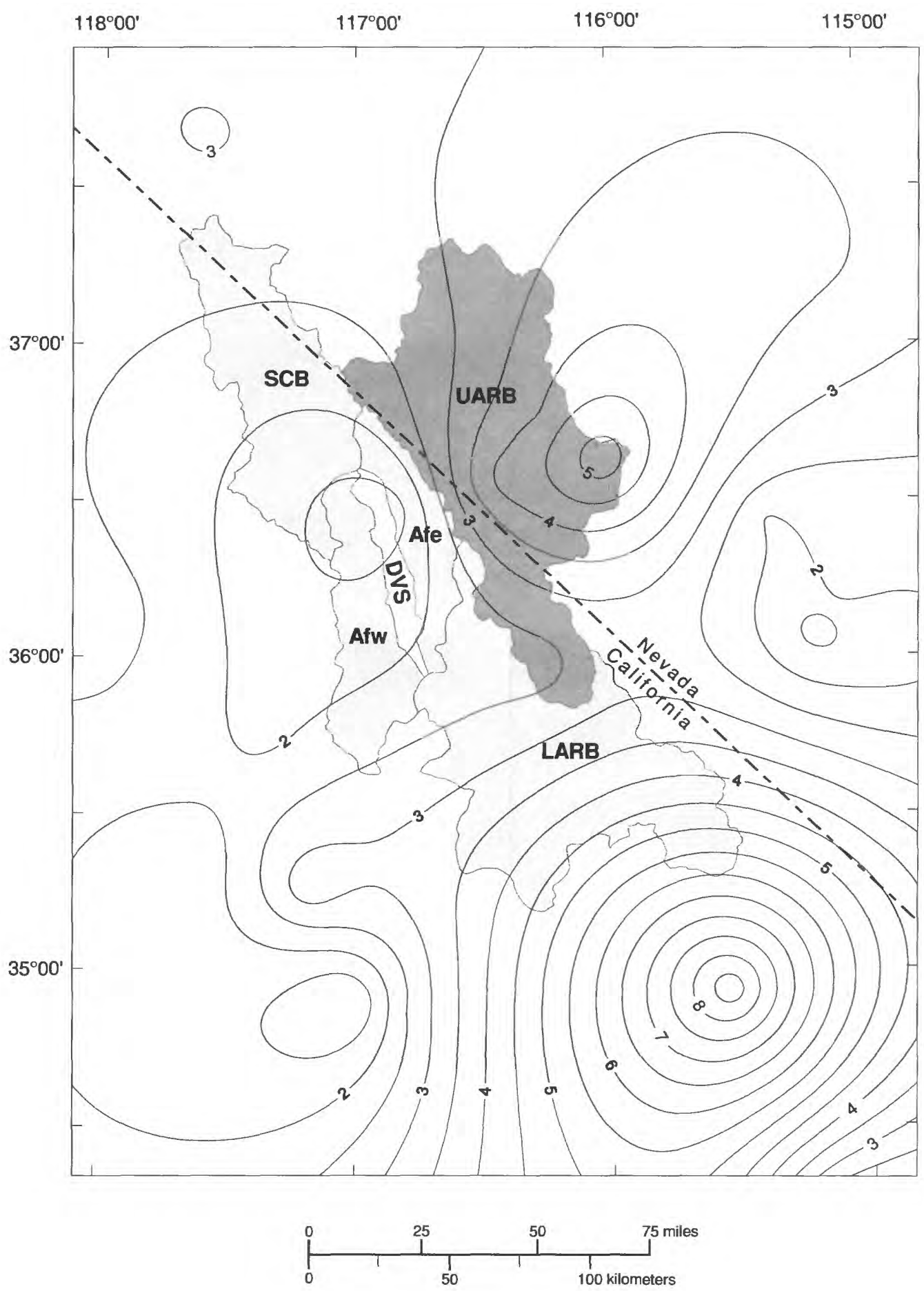

Figure 11. The distribution of August 1983 precipitation over the Death Valley watershed in southern Nevada and southeastern California. Figure 6 shows the location of NOAA and NTS weather stations used for contouring. 


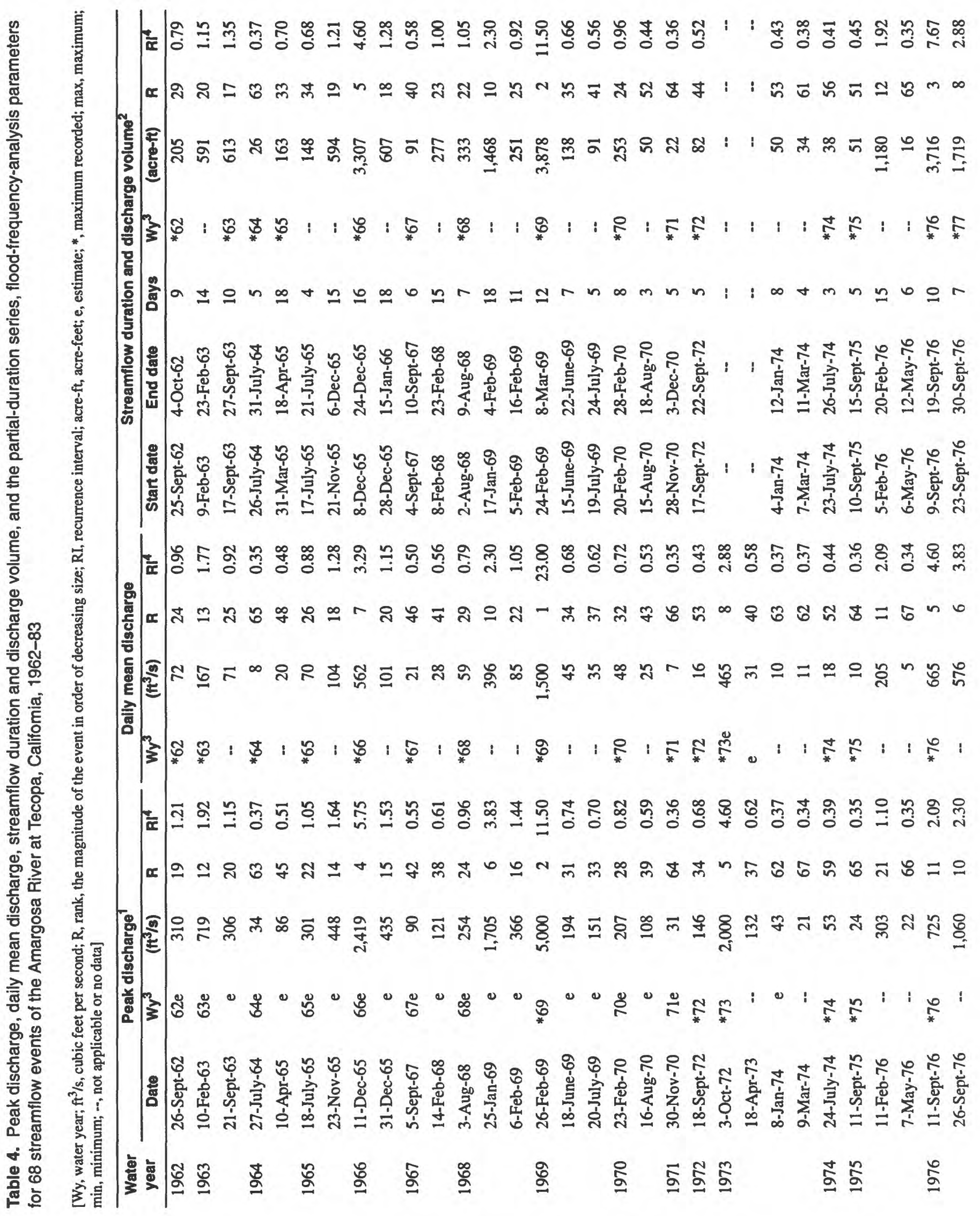




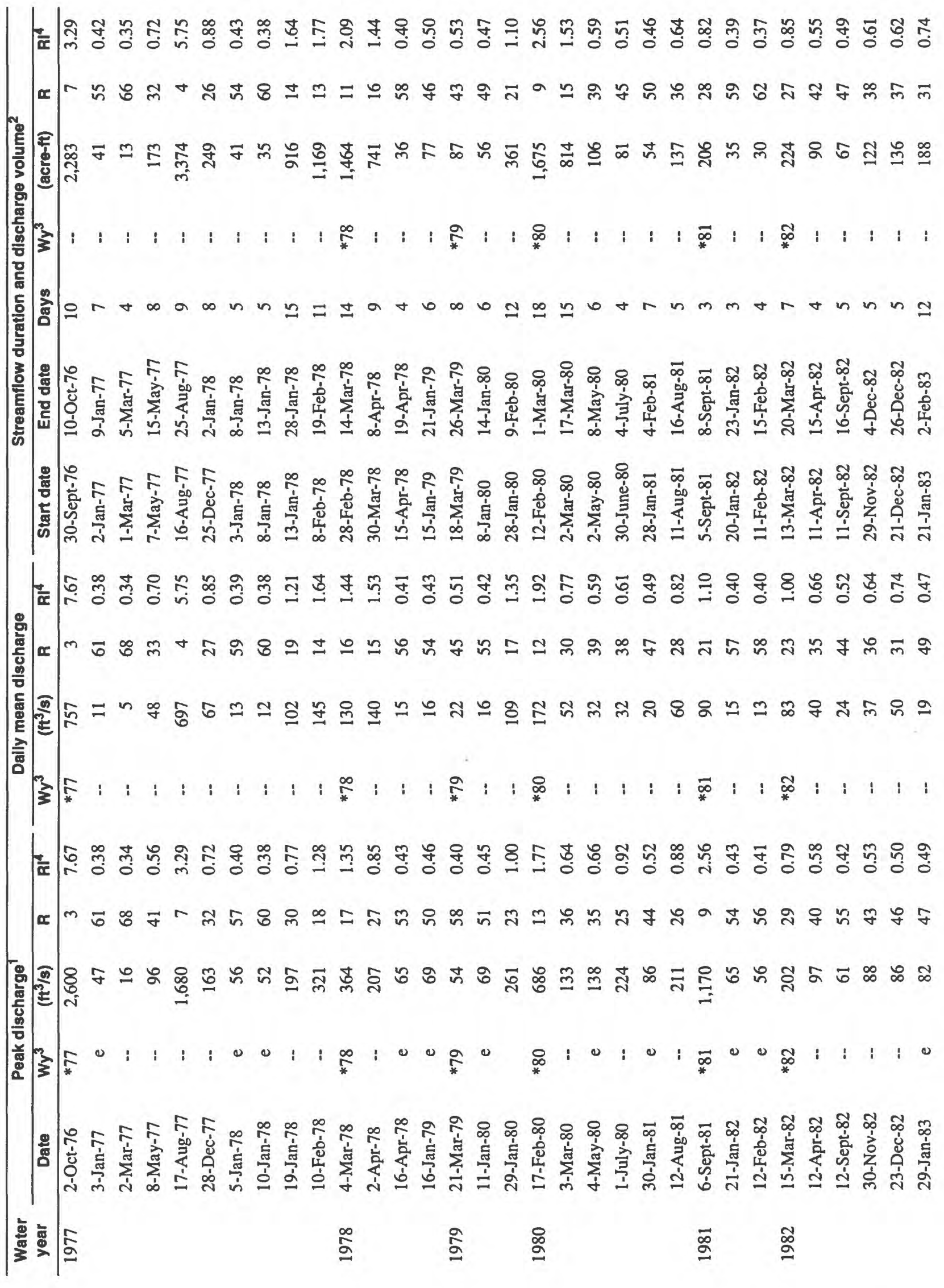




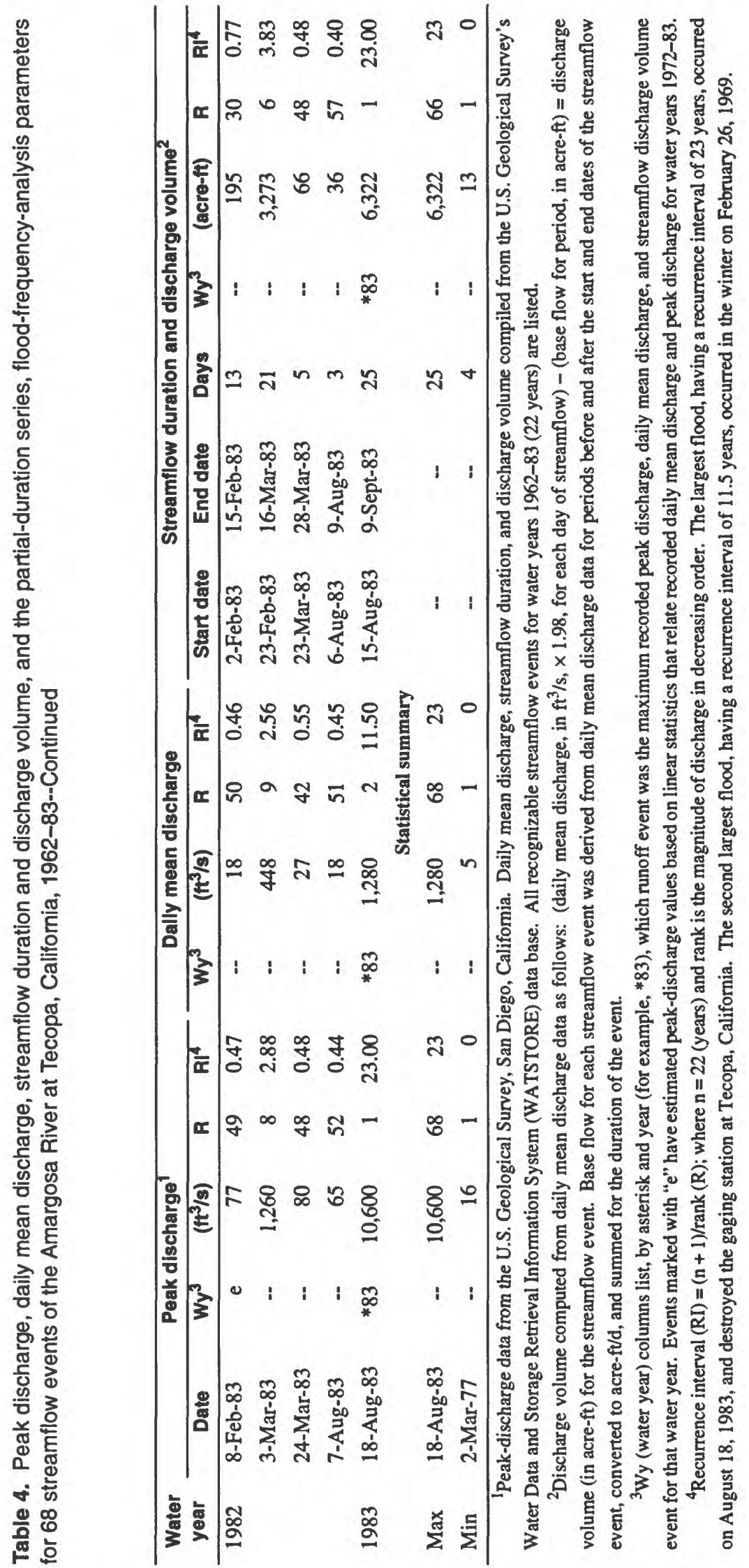

24 Hydrology of Modern and Late Holocene Lakes, Death Valley, California 


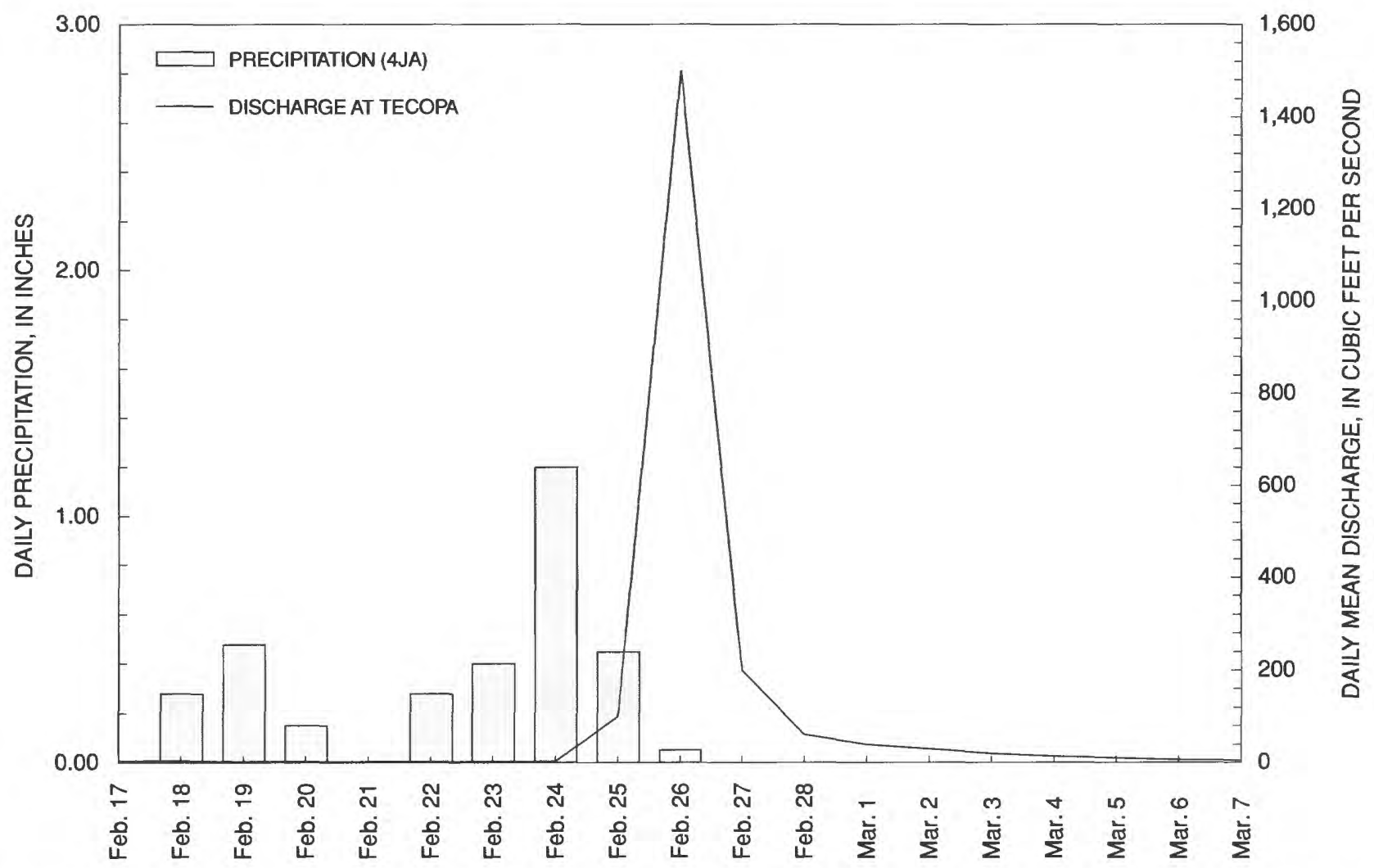

Figure 12. Hydrograph of the Amargosa River, February 17-March 7, 1969, showing daily rainfall at Nevada Test Site weather station 4JA, in inches, and daily mean discharge at Tecopa, California, in cubic feet per second.

produced by moderate, slow-moving winter fronts such as the February-March 1969 storms, and by slowmoving, late-summer tropical storms such as Hurricane Kathleen.

\section{Flood Frequency}

Flood frequency analyses were conducted on peak discharges, daily mean discharges, and stormrunoff volumes recorded for the Amargosa River at Tecopa, California, 1962-83. These analyses were conducted to (1) determine the recurrence intervals of floods, (2) extend the modern flood record of the Amargosa River, and (3) establish parameters for estimating the discharges and runoff volumes of different recurrence-interval floods from ungaged drainage basins in the Death Valley watershed. Flood frequency analyses were performed following methods outlined by Benson (1962; 1964), Cruff and Rantz (1965), Dalrymple (1970), Thomas (1987), and the Hydrology Subcommittee (1982).
A partial-duration-series analysis of flood frequency was conducted on Amargosa River streamflows with peak discharges greater than $100 \mathrm{ft}^{3} / \mathrm{s}$ and combined with long-term, peak-discharge estimates from two regional log-Pearson type III analyses, one based on Amargosa River streamflow data (this report) and the other based on 12 long-term sites judged to be “... representative of data for the [Nevada] Test Site in general and the Fortymile Wash study area in particular" (Squires and Young, 1984, p. 16). This comparison was possible because a strong correlation exists between discharge and drainage basin areas for streams with similar physiography, hydrology, and catchment size in the United States (Benson, 1964; Hedman, 1970; Thompson and Benson, 1970; Hedman and Osterkamp, 1982), and because statistical formulas that relate discharge to drainage basin area can be used to estimate long-term flood discharge rates (Crippen and Bue, 1977; Waananen and Crippen, 1977; Squires and Young, 1984). The regional log-Pearson type III analysis of Amargosa River discharge data, applied directly 


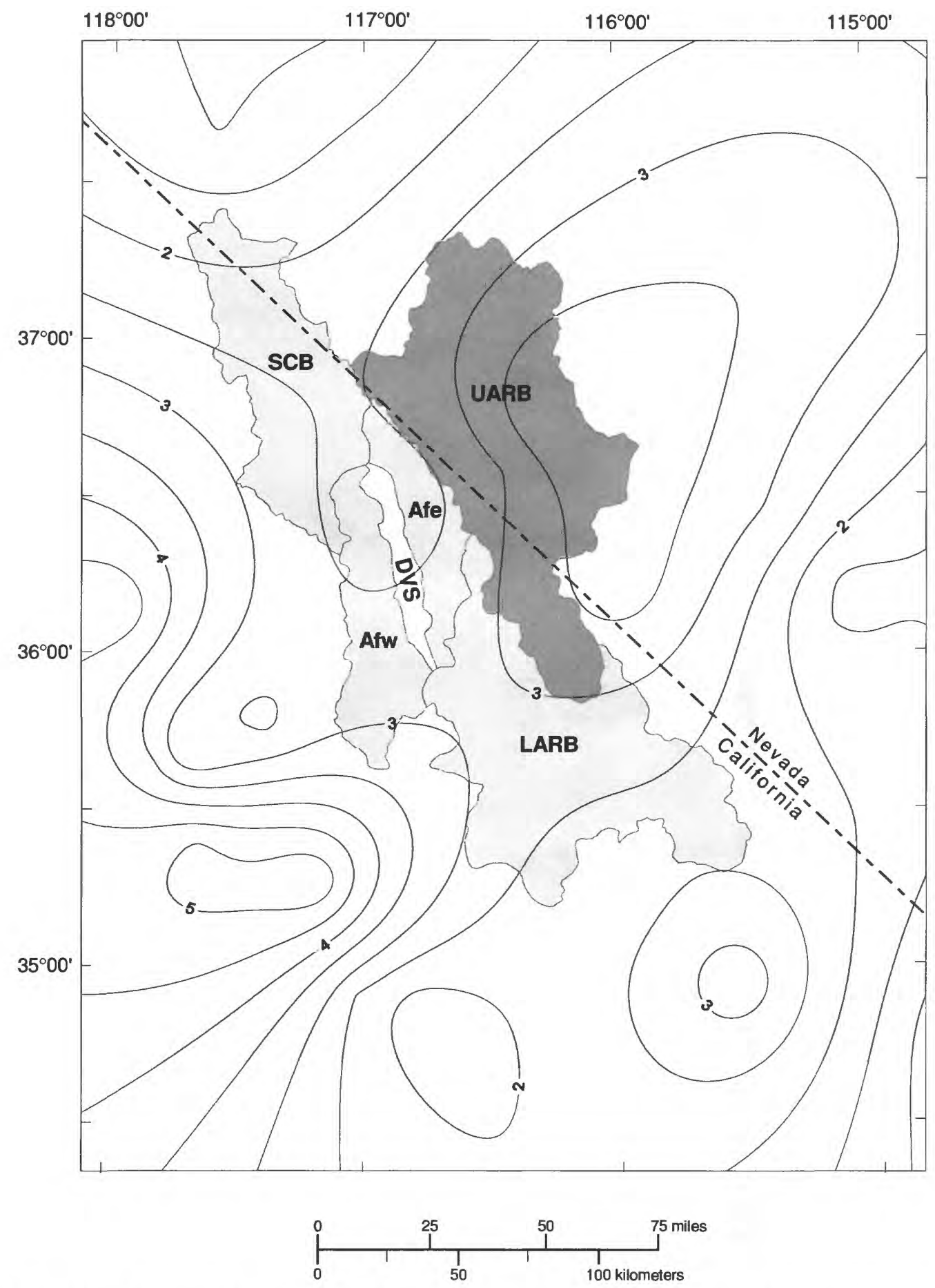

Figure 13. The distribution of February-March 1969 precipitation over the Death Valley watershed in southern Nevada and southeastern California. Figure 6 shows the location of NOAA and NTS weather stations used for contouring. 


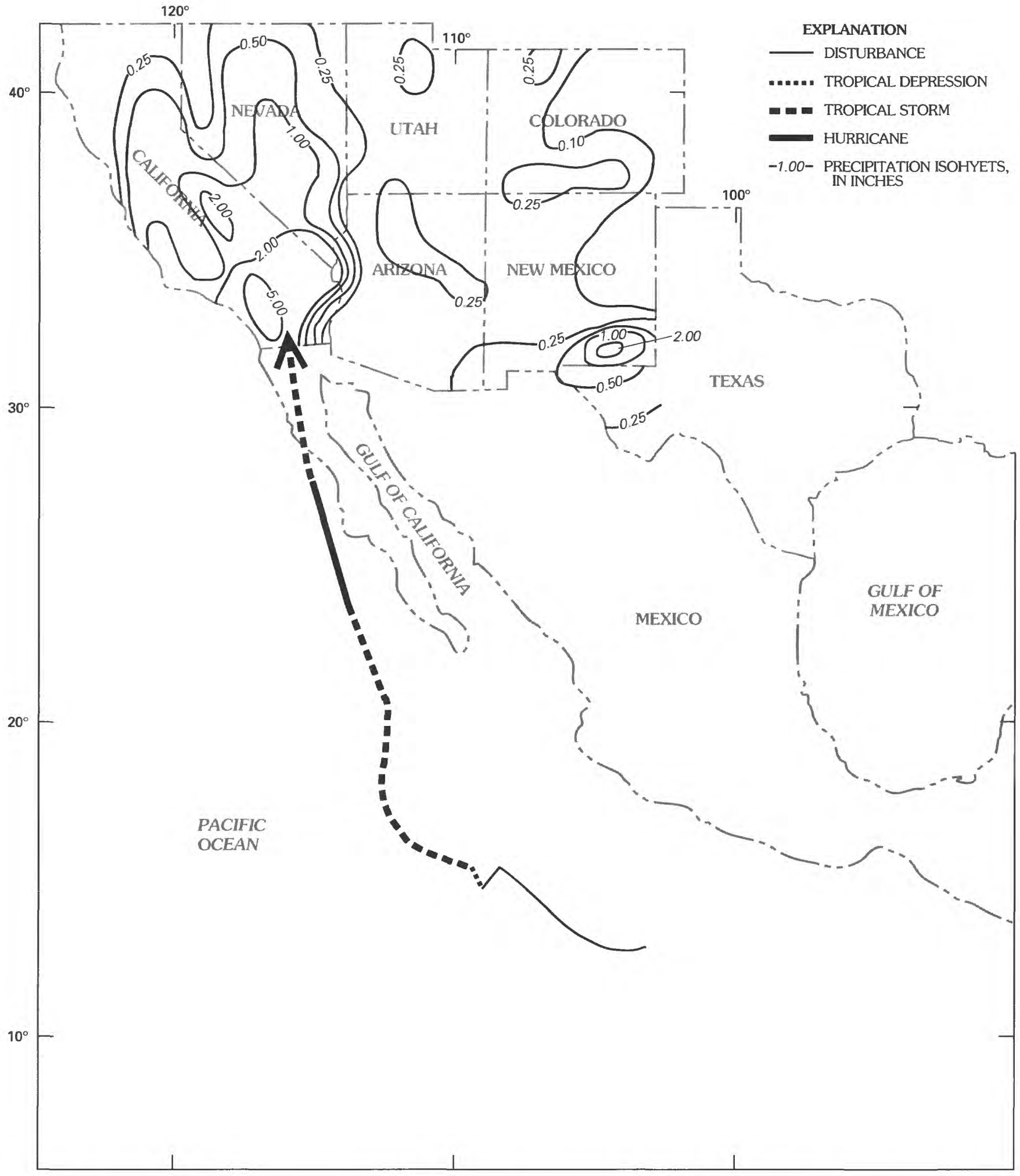

Figure 14. Track of Hurricane Kathleen, September 6-10,1976, and associated rainfall over the Southwestern United States. Precipitation totals are in inches; isohyets are drawn at $0.10,0.25,0.50,1.00,2.00$, and 5.00 inches (modified from Smith, 1986, p. 162). 


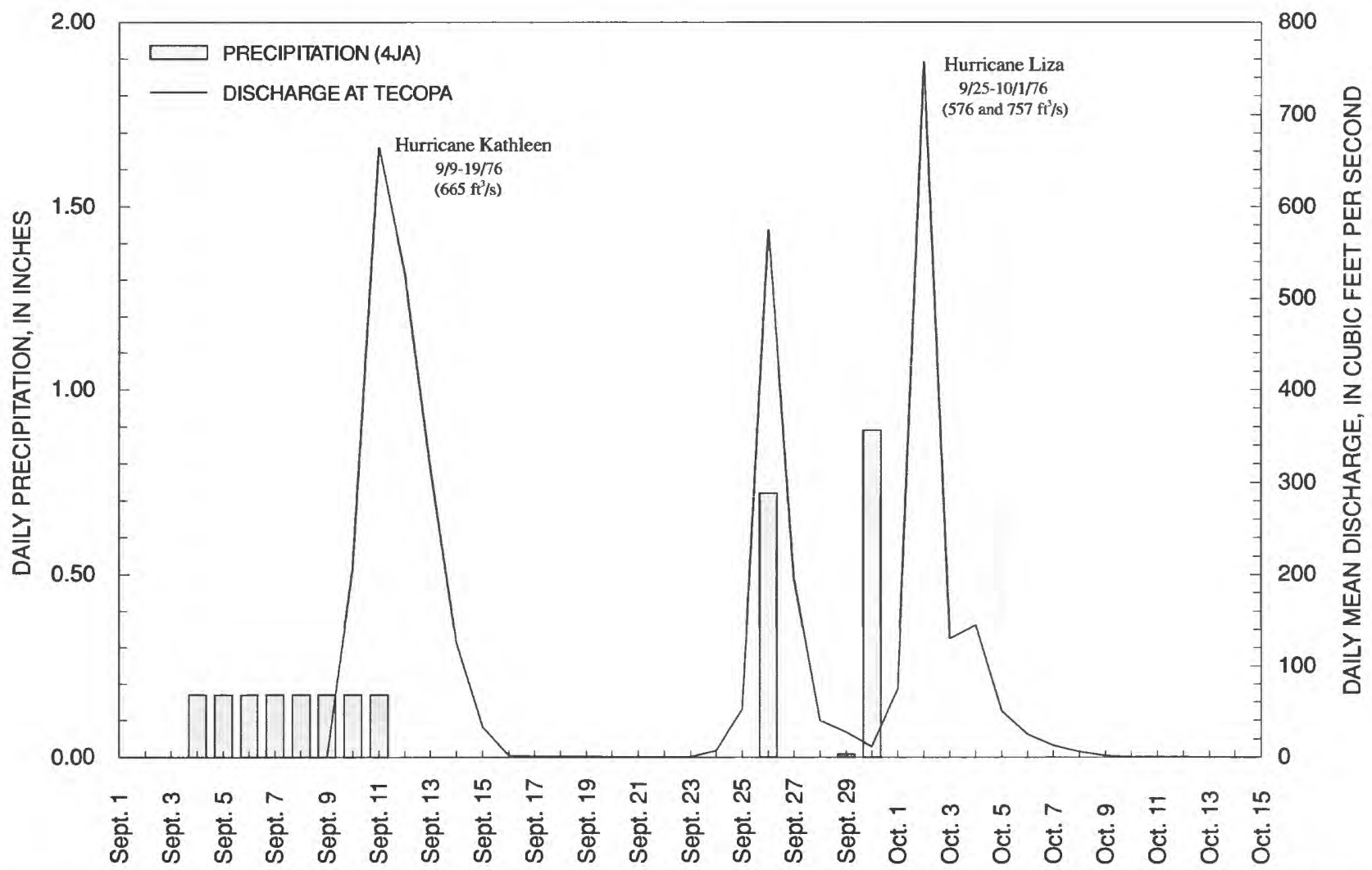

Figure 15. Hydrograph of the Amargosa River, September 1-October 15, 1976, showing daily rainfall at Nevada Test Site weather station 4JA, in inches, and daily mean discharge at Tecopa, California, in cubic feet per second.

to annual peak discharges greater than $100 \mathrm{ft}^{3} / \mathrm{s}$, afforded a means of extending the Amargosa River flood record. This regional analysis method is identical to the standard log-Pearson type III method, except that it uses a regionalized skew coefficient prepared by the U.S. Geological Survey (Hydrology Subcommittee, 1982, fig. 14-1). The generalized skew coefficient for the Death Valley watershed ranges from 0.0 on the east to 0.1 on the west. For this analysis, a skew coefficient of 0.0 was chosen to compute the peak discharge rates of long recurrence-interval floods because the skew coefficient that was computed using the Amargosa River data was nearer to $0.0(0.009)$ than to 0.1 .

Recorded and estimated peak discharges of streamflows with recurrence intervals of 1 to 500 years are shown in figure $\mathbf{1 6}$ for the Amargosa River at Tecopa, California. Peak discharges with recurrence intervals of 1 to 23 years were determined directly from streamflow data recorded at Tecopa, 1962-83. Longer recurrence intervals were estimated using two, logPearson type III analyses for the area. The regional
log-Pearson type III analysis of the Amargosa River (this report) indicates that peak discharges of 11,706; 18,$647 ; 28,555$; and $47,858 \mathrm{ft}^{3} / \mathrm{s}$ are possible from the 50-, 100-, 200-, and 500-year floods (fig. 16). These values are considerably lower than those computed for the upper Amargosa River Basin using Squires' and Young's (1984) equations for the 100- and 500-year floods (fig. 16). Squires' and Young's (1984) equations $\left(Q_{100}=482 \times A^{0.565}\right.$ and $Q_{500}=2,200 \times A^{0.571}$, where $A$ is drainage basin area, in square miles) give estimated peak discharges for the Amargosa River at Tecopa of 45,179 and $216,353 \mathrm{ft}^{3} / \mathrm{s}$ for the 100 - and 500 -year floods. Although these values are within the limits of the regional maximum flood computed for the upper Amargosa River Basin, they are undoubtedly less reliable than the regional log-Pearson type III estimates based directly on Amargosa River streamflow data (this report) because Squires' and Young's (1984) equations were derived for drainage basins of less than $470 \mathrm{mi}^{2}$ in size. 


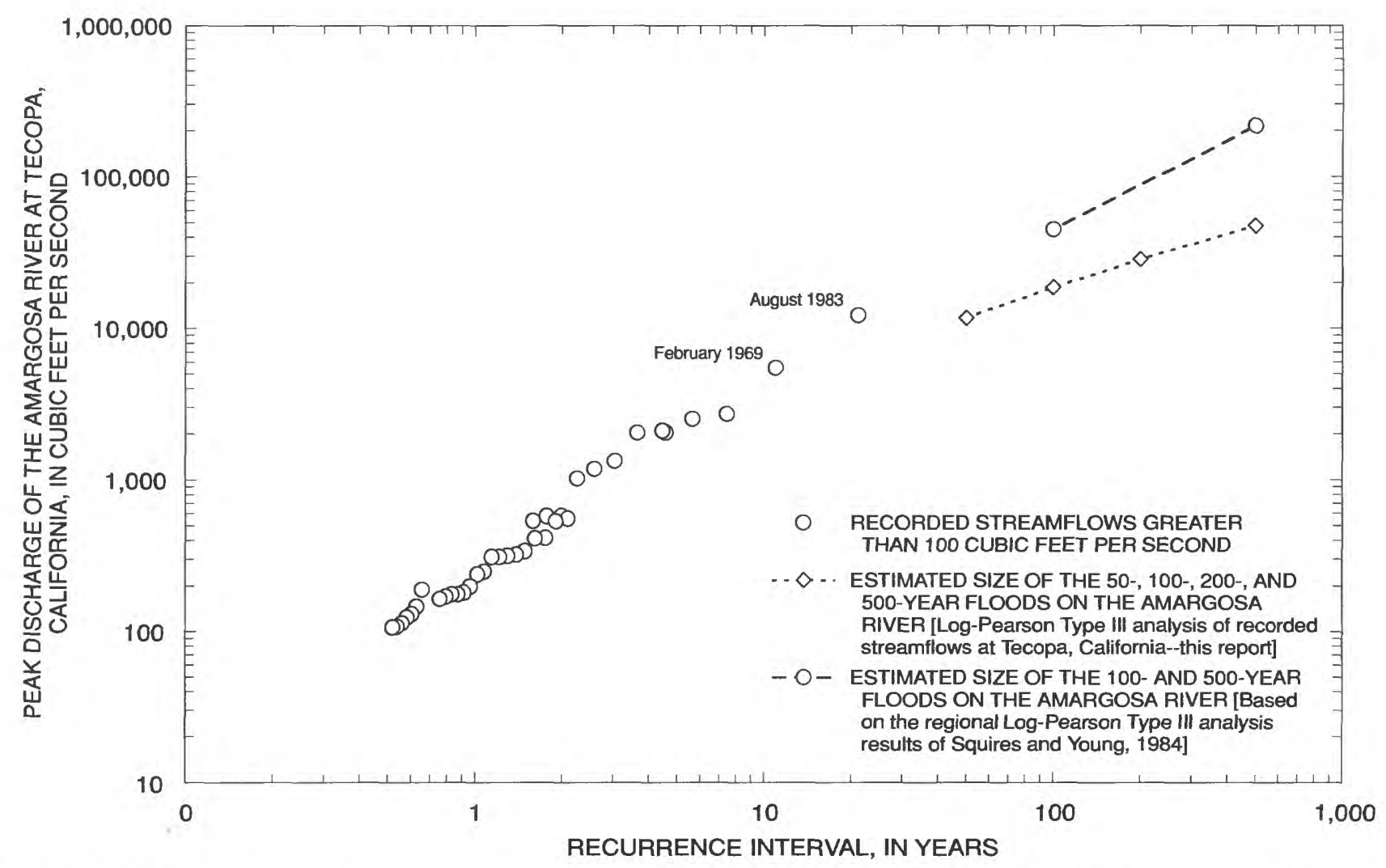

Figure 16. Peak discharge and recurrence interval of recorded and estimated streamflows greater than 100 cubic feet per second for the Amargosa River at Tecopa, California.

\section{Local and Regional Maximum Floods}

A comparison of local and regional maximum floods that occurred in and around the study area was made to evaluate the size of the probable maximum flood from drainage basins of the Death Valley watershed. Streamflow data for regional floods of unusually large magnitude in Arizona, California, Nevada, New Mexico, and Utah (Crippen and Bue, 1977, p. 15) give a maximum boundary (envelope) curve for the regional maximum flood. Streamflow data for local floods of drainages in and around the upper Amargosa River Basin and Nevada Test Site (Squires and Young, 1984; Bullard, 1992) give a somewhat lower boundary (envelope) curve for the local maximum flood (fig. 17). These curves, which relate peak discharge to drainagebasin area, are based on recorded flood data from different-size drainages in the Southwestern United States without regard to the recurrence interval, and thus, larger magnitude floods may occur in the future.
The maximum flood potential of drainage basins in the Death Valley watershed probably is somewhere between the two curves shown in figure 17, and may actually be limited by the probable maximum rainfall for the area (Enzel and others, 1993). In a regional analysis of floods, Crippen $(1979 ; 1982)$ developed a general equation for estimating the maximum flood for desert streams in Death Valley and the Basin and Range Province. The equation that was developed by Crippen (1979) and reported in Bowers $(1990$, p. 7) for the Death Valley area, is: $Q_{m e}=66,000 \times A^{1.029} \times Z^{-1.341}$ (where, $Q_{m e}$ is the maximum estimated flood discharge, in cubic feet per second; A is drainage-basin area, in square miles; and $\mathrm{Z}=\mathrm{A}^{0.5}+5$ ) The computed peak discharges of the maximum estimated flood $\left(\mathrm{Q}_{\mathrm{me}}\right)$ from drainage basins of the Death Valley watershed are shown on figure 17 compared to the magnitudes of local and regional maximum floods. The $\mathrm{Q}_{\mathrm{me}}$ equation gives the following maximum estimated discharges: $1,048,400 \mathrm{ft}^{3} / \mathrm{s}$ for the upper Amargosa River Basin; 


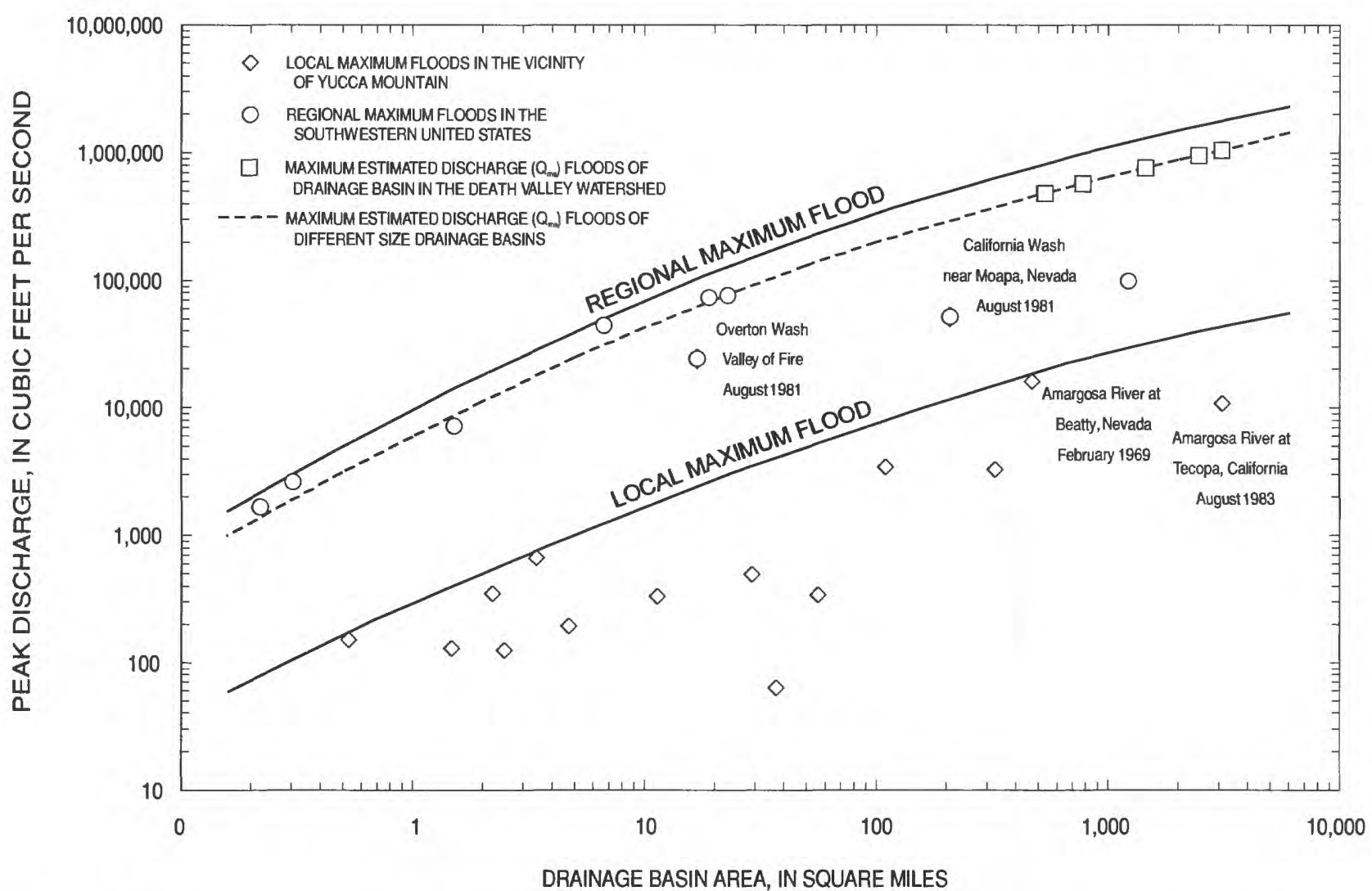

Figure 17. Envelope curves of the potential local and regional maximum floods from different-size drainage basins in the Southwestern United States.

$952,700 \mathrm{ft}^{3} / \mathrm{s}$ for the lower Amargosa River Basin; $760,500 \mathrm{ft}^{3} / \mathrm{s}$ for Salt Creek Basin; and 576,000 and $482,100 \mathrm{ft}^{3} / \mathrm{s}$ for west and east side alluvial fan drainage basins. The maximum estimated flood $\left(\mathrm{Q}_{\mathrm{me}}\right)$ for these basins falls within the regional and local envelope curves shown on figure 17 and approximates the higher five-State regional maximum flood defined by Crippen and Bue $(1977$, p. 15) for the Southwestern United States.

\section{Flood-Runoff Volumes}

Flood runoff from a drainage basin is dynamically related to drainage basin size (Thomas and Benson, 1970) and to storm duration and intensity, which control the amount of precipitation received by the basin (Enzel and others, 1993). In addition to these dominant controls, flood runoff is governed by such drainage basin characteristics as the infiltration rate and capacity of a basin's surface material and evapotranspiration; a factor that changes relative to variations in climate and vegetation type and cover throughout a basin. Because these interrelated factors would have been difficult to accurately quantify for each basin of the 8,310- $\mathrm{mi}^{2}$ Death Valley watershed catchment (table 1), the power equation $\left(y=c x^{b}\right)$ was used to develop a general numeric relation between peak discharge and runoff for the watershed based on recorded streamflow data of the Amargosa River.

The relations between peak discharge, in $\mathrm{ft}^{3} / \mathrm{s}$, and runoff, in acre-ft, for 34 streamflow periods (19 winter and 15 summer) on the Amargosa River at Tecopa, California, are shown in figure 18. These linear, power-series curves have $\mathrm{R}^{2}$ (coefficient of determination) values of 0.84 (winter), 0.83 (summer), and 0.79 (all storms) and effectively account for inherent seasonal differences in precipitation, rainfall intensity, and duration, and for variations in infiltration and evapotranspiration within the upper Amargosa River 


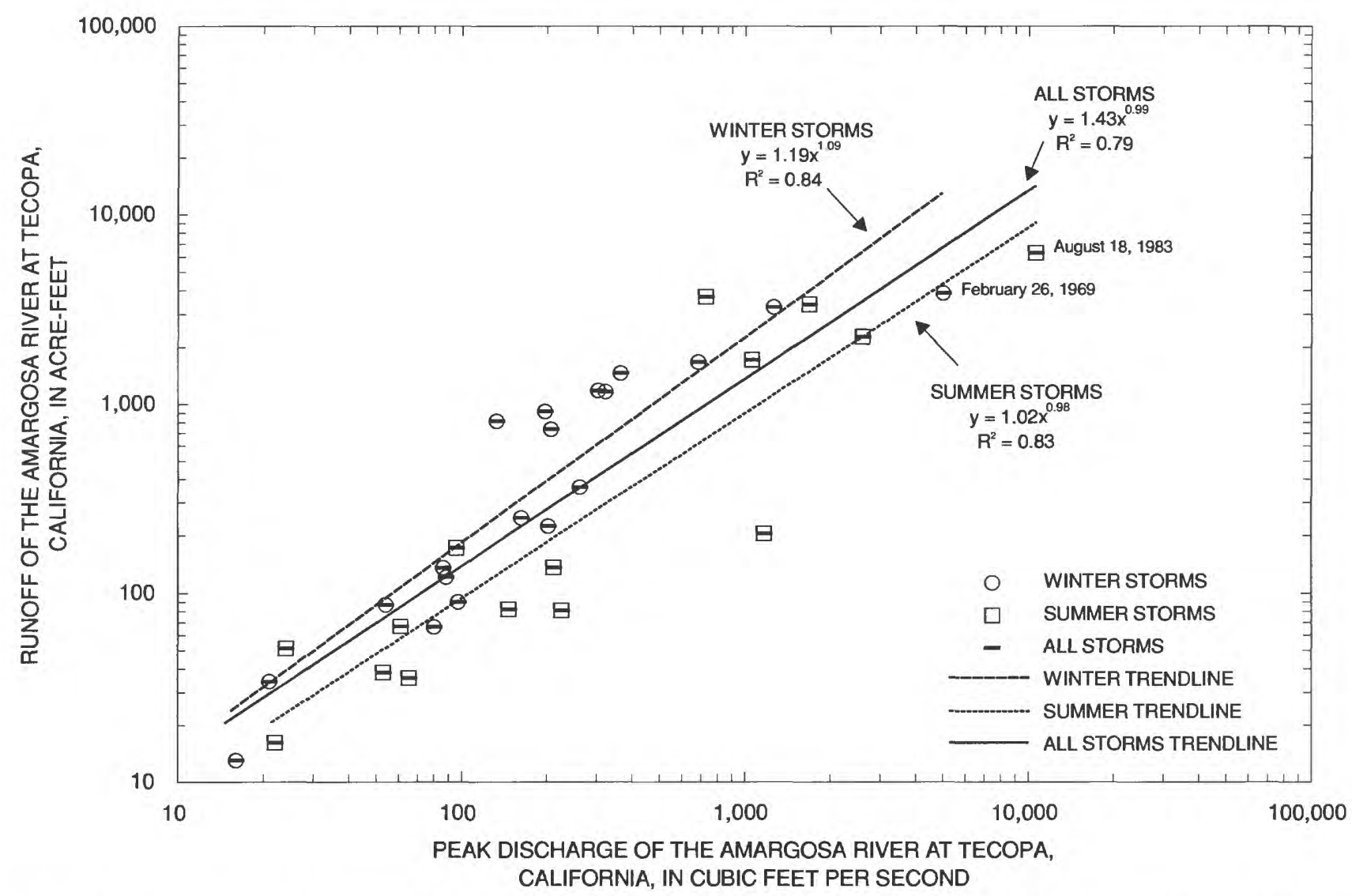

Figure 18. Linear relations of recorded runoff to peak discharge for 34 streamflow periods of the Amargosa River at Tecopa, California, 1968-83.

Basin. The all storms curve has the lowest correlation coefficient because it must accommodate the seasonal precipitation-runoff variability that exists between winter and summer storms over the basin (fig. 9). The winter and summer curves have similar correlation coefficients, but the steeper slope of the winter curve (fig. 18) indicates that for a given peak-discharge flood, runoff tends to be higher for winter storms than summer storms; a factor that is undoubtedly related to the inherent nature of winter storms, which tend to be less intense and of longer duration than summer storms.

Although the numerical relations shown in figure 18 only approximate the regional runoff characteristics of the upper Amargosa River Basin, they can be used to evaluate the potential volume of runoff for long-recurrence-interval floods on the Amargosa River (for example, the 25- and 50-year floods) and to estimate the volume of runoff from nearby, ungaged drainage basins of the Death Valley watershed. Together, these estimates provide a measure of the potential, cumulative runoff from the watershed for different recurrence-interval storms and floods. The cumulative runoff from the watershed is important because this runoff could ultimately produce a lake in Death Valley.

The runoff volumes for different-size floods from drainage basins of the Death Valley watershed are listed in table 5. Peak discharges on the Amargosa River are listed for floods that have recurrence intervals of 1.20 to 500 years and for the maximum estimated flood $\left(\mathrm{Q}_{\mathrm{me}}\right)$. The peak discharges of floods having recurrence intervals less than 25 years are based on the log-Pearson type III analysis of streamflow data recorded on the Amargosa River at Tecopa, 1962-83 (this report). The peak discharges of floods having recurrence intervals of $25,50,200$, and 500 years are an average of the two, log-Pearson curves shown in figure 16. The maximum estimated flood $\left(Q_{m e}\right)$ for the Amargosa River was computed using the formula given in the previous section. 


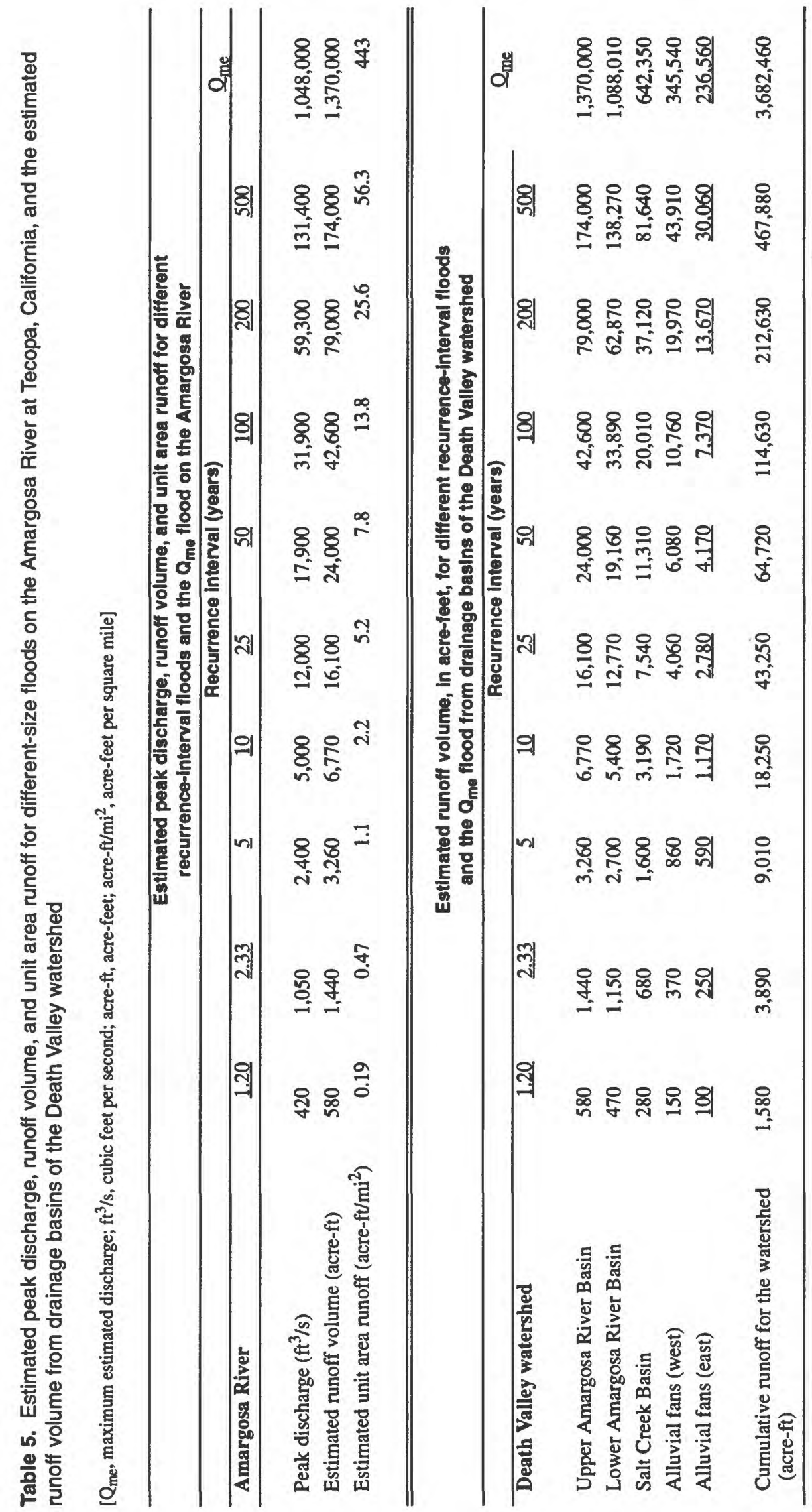


The volume of runoff for each Amargosa River flood was computed using the all storms linear equation $\left(y=1.43 \times{ }^{0.99}\right)$ shown in figure 18 , and the unit area runoff, in acre-feet per square mile, was calculated for the upper Amargosa River Basin (table 5). The volume of runoff for different recurrence-interval floods and the $Q_{m e}$ flood was then estimated for other, ungaged drainage basins of the Death Valley watershed by multiplying basin area, in square miles, by the unit area runoff estimated for the upper Amargosa River Basin. Drainage basin runoff and the cumulative runoff of the watershed for these different recurrenceinterval floods are shown in table 5. It should be noted that the runoff volumes listed in table 5 afford only estimates of the potential cumulative volume of runoff from the watershed, because they were computed indirectly from recorded runoff of the Amargosa River at Tecopa, California. Other drainage basins in the watershed may have different hydrologic characteristics, and thus different runoff potential.

The result of these flood-volume computations was the estimated cumulative runoff of the Death Valley watershed catchment for different recurrenceinterval storms. Although these computations only approximate the flood runoff potential of the catchment, they indicate that a flood with a recurrence interval between 25 and 50 years could produce a lake similar in size to the winter 1969 lake in Death Valley, a lake Hunt (1975) estimated to contain about 50,000 acre-feet of water, without the addition of water from direct precipitation or ground-water sources. The streamflow record of the Amargosa River, however, indicates that ephemeral lakes in Death Valley are not produced by a single large-magnitude flood, but rather by frequent, above-normal winter streamflows, and that without water from direct precipitation and ground-water-discharging springs in the area, these lakes could not form under the modern hydroclimatic regime of the watershed. For example, cumulative streamflow runoff from the watershed for the winter 1969 lake was estimated to be only about 50 percent of the total volume of the winter 1969 lake in Death Valley, and this volume of runoff included the 11.5-year-recurrence-interval flood on the Amargosa River in late February 1969.

\section{HYDROCLIMATOLOGY OF DEATH VALLEY LAKES}

Shallow ephemeral lakes can form in Death Valley as a result of frequent and prolonged winter to late-spring precipitation and runoff. During an average year, the Death Valley saltpan is dry because of low annual precipitation-runoff, intense heat, and high potential lake evaporation of about 82 in. annually (Meyers, 1962; Hunt and others, 1966). Periodically, however, above-normal streamflow from the watershed will inundate the saltpan to form a shallow lake. These ephemeral lakes commonly form in late winter (February-March) when streamflow from the watershed and direct precipitation onto the playa and expanding lake surface are high and evaporation is low. Between 1962 and 1983, periods of high winter runoff on the Amargosa River and the formation of ephemeral lakes in Death Valley have generally coincided with the occurrence of the ENSO. These events were particularly correlative in the winters of 1966, 1969, 1973, 1978, and 1983 (figs. 7 and 8). Since the destruction of the gaging station at Tecopa in August 1983, ephemeral lakes have also formed in Death Valley during moderate to strong ENSO events in the winters of 1984,1992 , and 1993. The 1993 lake (fig. 1), for example, was formed by a series of slow-moving storms that produced frequent, above-normal rainfall over the watershed and above-normal streamflows on the Amargosa River. This fluvial-lacustrine relation indicates that cumulative streamflow from the Death Valley watershed catchment and direct precipitation onto the Death Valley saltpan are periodically sufficient to produce a lake of considerable size in Death Valley. Furthermore, the relation between rainfall-runoff and lake formation in Death Valley indicates the existence of a hydroclimatic balance between the size (or volume) of the ephemeral lake and the volume of surface-water from the closed-basin watershed. The prior existence of a large, late Holocene perennial lake in Death Valley therefore suggests that a different hydroclimatic regime may have dominated the region in late Holocene.

\section{Regional Late Holocene Climate Change}

Variations in climate during the late Holocene affected hydrologic change in glacial and nonglacial areas of western North America. Cool, moist Neoglacial climates caused alpine glacier advancements 
(Porter and Denton, 1967; Denton and Porter, 1970; Miller, 1973; Andrews and others, 1975; Burke and Birkeland, 1983; Grove, 1988); altitudinal reductions in treeline (LaMarche, 1974; Brubaker and Cook, 1983); closed-basin lake transgressions (Smith, 1979; Lajoie and Robinson, 1982; Enzel and others 1989; Waters, 1989; Stine, 1990; Benson and others, 1991; Enzel and others, 1992; Vance and others, 1992); the formation of peat bogs in desert basins (Mehringer and Warren, 1976); and increased floods and debris flows (Weldon, 1990; Ely and others, 1993). Conversely, intervening periods of warmer and drier climate reversed these trends. Researchers (for example, LaMarche, 1974; Benson and others 1991) generally agree that cooler and wetter conditions prevailed between about 4.0 to $3.0 \mathrm{ka}, 1.8$ to $1.0 \mathrm{ka}$, and 0.7 to $0.1 \mathrm{ka}$, whereas warmer and drier conditions similar to those of today (1995) prevailed about $2.0 \mathrm{ka}, 1.0 \mathrm{ka}$, and after $0.1 \mathrm{ka}$.

Various reports of geologic, botanical, and hydrologic evidence for two prominent and widespread late Holocene climatic periods in the Western United States are listed in tables 6 and 7. The effects of these regional, Neoglacial periods are primarily evidenced by glacial landforms, sediments, and soils from high-altitude alpine (glacial) locations, and by closedbasin lacustrine features and various kinds of geobotanical evidence from low-altitude desert (nonglacial) locations. In nonglacial desert areas of the Southwestern United States, two prominent periods of cooler and wetter climate have been well documented for an early Neoglacial period that occurred about 4.0 to $3.0 \mathrm{ka}$ (table 6) and a late Neoglacial period that occurred about 0.7 to $0.1 \mathrm{ka}$ (table 7).

Antevs (1948) first recognized that a single late Holocene period of cool and moist glacial climates (the Medithermal) occurred in the Western United States about $4.5 \mathrm{ka}$ to the present (1995) following a hotter and drier climate period (the Altithermal), which occurred about 7.5 to $4.5 \mathrm{ka}$. Since 1948 , several researchers have more clearly defined the environmental response and timing of these late Holocene climatic periods. Richmond (1965) reported that two glaciations, Temple Lake and Gannett Peak Stades, occurred in the Rocky Mountains followed the Altithermal. These glaciations are recorded by deposits of the Temple Lake A and B advances (3.1-1.8 ka and 1.8-1.05 ka) and by the Gannett Peak advance (0.8$0.1 \mathrm{ka})$. Porter and Denton (1967) reported evidence for at least three Neoglacial advances (early, intermedi- ate, and late) from widespread alpine locations throughout much of Western North America. Although Neoglacial advances have been dated to as early as $5.26 \mathrm{ka}$ in the Cascade Mountains of Washington and $4.77 \mathrm{ka}$ in the Crows Nest Mountains of southeastern British Columbia, Canada, the bulk of evidence indicates that late Holocene glaciation began about 4.5 to $4.0 \mathrm{ka}$. For example, Benedict (1973) reported that an early Neoglacial advance, Triple Lakes Glaciation, occurred in the Colorado Front Range between about 4.5 and $3.0 \mathrm{ka}$, and that this advance was followed by a warm and dry soil-forming period (3.0-1.85 ka) and by two late Holocene glaciations, Audubon and Arapaho Peak Glaciations (1.85-1.0 ka and 0.3-0.1 ka). Farther west in the Sierra Nevada, three post-altithermal glacial advances also occurred during the late Holocene. The earliest, the Recess Peak Glaciation, was dated to about $3.0 \mathrm{ka}$. This glacial advance was followed by an unnamed glaciation about $1.1 \mathrm{ka}$ and by the Matthes Glaciation (Little Ice Age) about 0.35 to $0.30 \mathrm{ka}$ (Burke and Birkeland, 1983).

The nature and timing of these Neoglacial climatic periods in the Western United States are important to the paleohydrology of the Death Valley watershed because of the widespread effects they had on landscape-forming processes in nonglacial, desert locations. For example, fluvial and eolian stratigraphic sequences in nonglacial areas of the West indicate that at least three Neoglacial climatic periods occurred after 4.5 ka (Haynes, 1967; Andrews and others, 1975; Gaylord, 1982). Similarly, lacustrine sediments and landforms in the Great Basin indicate the prior occurrences of two or three lake-forming events related to climate changes that occurred shortly after $4.8 \mathrm{ka}$ (Benson and others, 1991; Enzel and others, 1992).

The paleolake work by Enzel and others (1992) in the Silver-Soda Lake Basin at the terminus of the Mojave River in southeastern California is particularly relevant to the Death Valley watershed in that evidence is well documented for perennial lakes in the basin during two late Holocene periods centered at 3.6 and $0.39 \mathrm{ka}$ (tables 6 and 7). The existence of these paleolakes, which may have lasted for several decades, indicates that floods comparable in size to the largest in the modern flood record of the Mojave River may have occurred annually (Enzel, 1992, p. 11). The close proximity of the Silver-Soda Lake Basin in the Mojave Desert, south of the Death Valley watershed, indicates that similar lacustral events also may have occurred in the Death Valley watershed during these late Holocene 
Table 6. Regional lacustrine, hydrologic, and biogeographic evidence of early Neoglacial climate change in nonglacial areas of the Western United States

[ka, kilo-annum, thousands of years before present (B.P., 1950), unless otherwise indicated; $\sim$, approximate; ft, feet]

\begin{tabular}{|c|c|c|}
\hline Period & Description of change & Reference \\
\hline$\sim 3.6 \mathrm{ka}$ & $\begin{array}{l}\text { A shallow perennial lake occupied the Silver Lake Basin at the terminus of the } \\
\text { Mojave River for several decades about } 3,620 \pm 70 \text { radiocarbon years ago (dates } \\
\text { from lake and shore deposits). The lake was produced by an increase in the fre- } \\
\text { quency of winter storms in the Southwestern United States. }\end{array}$ & Enzel and others $(1989 ; 1992)$ \\
\hline $5.0-2.0 \mathrm{ka}$ & $\begin{array}{l}\text { A perennial lake may have occupied the Death Valley saltpan, California, for several } \\
\text { decades during this period. The lake was about } 40 \text { to } 50 \mathrm{ft} \text { deep. }\end{array}$ & Hunt $(1966 ; 1975)$ \\
\hline$\sim 3.5 \mathrm{ka}$ & $\begin{array}{l}\text { A saline lake rose to about } 148 \mathrm{ft} \text { above the present playa in the Searles Lake Basin, } \\
\text { California. A date of } 3,520 \text { years B.P. was obtained from wood buried within } \\
\text { lacustrine deposits from the lake basin. }\end{array}$ & Smith (1979) \\
\hline$-4.8-2.7 \mathrm{ka}$ & $\begin{array}{l}\text { Highstand of Walker Lake, California. Lacustrine sediments record a high lake level } \\
\text { for the period following shallow (possibly desiccated) lake conditions of } 5.3 \text { to } \\
4.8 \mathrm{ka} \text {. Highstands also occurred at } 1.25 \mathrm{ka} \text { and after } 0.3 \mathrm{ka} \text {. }\end{array}$ & Benson and others (1991) \\
\hline$-3.77 \mathrm{ka}$ & $\begin{array}{l}\text { Highstand of Mono Lake, California. A calibrated date records the approximate } \\
\text { time of this lake-level highstand. Five peaks in lake size also occurred from } 1.6 \text { to } \\
0.2 \mathrm{ka} \text {. }\end{array}$ & Stine (1990) \\
\hline$\sim 4.0-3.0 \mathrm{ka}$ & $\begin{array}{l}\text { A lacustral event occurred in the Wilcox Playa Basin in southeastern Arizona during } \\
\text { this period. }\end{array}$ & Waters (1989) \\
\hline $4.4-1.0 \mathrm{ka}$ & $\begin{array}{l}\text { Alberta Lakes, North Dakota. Lacustrine deposits record rising water levels and } \\
\text { declining salinity }(4.4-2.6 \mathrm{ka}) \text { and a prolonged period of high water, low salinity, } \\
\text { and rare droughts }(2.6-1.0 \mathrm{ka}) \text {. }\end{array}$ & Vance and others (1992) \\
\hline $4.0-3.5 \mathrm{ka}$ & $\begin{array}{l}\text { A notable recharge of the ground-water aquifer in southwestern Nevada occurred } \\
\text { during this period. It was the only such recharge detected since about } 9 \mathrm{ka} \text {. }\end{array}$ & Benson and Klieforth (1989) \\
\hline $5.0-3.5 \mathrm{ka}$ & $\begin{array}{l}\text { Increased debris-flow activity occurred in the San Gabriel Mountains, southern } \\
\text { California, during this period. }\end{array}$ & Weldon (1990) \\
\hline $4.3-1.6 \mathrm{ka}$ & $\begin{array}{l}\text { Notably less arid conditions prevailed in Lucerne Valley in the western Mojave } \\
\text { Desert, California, during this period. }\end{array}$ & King (1976) \\
\hline $4.0-3.6 \mathrm{ka}$ & $\begin{array}{l}\text { Peat bogs formed in the Ash Meadows area of the upper Amargosa River Basin } \\
\text { (Amargosa Desert) in southern Nevada. }\end{array}$ & Mehringer and Warren (1976) \\
\hline $4.0-3.0 \mathrm{ka}$ & $\begin{array}{l}\text { The woodland boundary of southwestern Nevada was about } 492 \mathrm{ft} \text { lower during this } \\
\text { period, indicating moister conditions for the region. }\end{array}$ & Spaulding (1985) \\
\hline $3.5-2.0 \mathrm{ka}$ & $\begin{array}{l}\text { A significant decrease in tree-line elevation occurred in the White Mountains of } \\
\text { eastern California during this period. }\end{array}$ & LaMarche (1974) \\
\hline
\end{tabular}

periods. This and other widespread evidence of Neoglacial climate change in the region about $3.6 \mathrm{ka}$ also supports Hunt's $(1966 ; 1975)$ hypothesis for a short-lived (less than 100 years) perennial lake in Death Valley from about 5.0 to $2.0 \mathrm{ka}$.

\section{Modern Lakes}

Although the Death Valley watershed once received surface water from the Mojave River to the south (Yehoudan Enzel, Hebrew University of Jerusalem, Israel, oral commun., 1992) and possibly from the Owens River to the west (Smith and StreetPerrott, 1983), such inflow was only possible during the late Pleistocene (about $25-15 \mathrm{ka}$ ) when terminal lakes of these rivers, Lake Mojave in the Silver-Soda Lake Basin and Panamint Lake in Panamint Valley, overtopped their basin thresholds and spilled into Death Valley (fig. 19). Since the demise of these lakes about $15 \mathrm{ka}$, these surface-water linkages between basins have not been possible. A modern water budget of a closed-basin lake in the Death Valley watershed was therefore needed as an analog to determine the requisite hydroclimatic measures for a large, late Holocene lake in Death Valley.

\section{Water Budget for Closed-Basin Lakes}

The modern hydroclimatic record of the closedbasin Death Valley watershed indicates that lakes are formed predominately by winter to early-spring runoff 
Table 7. Regional lacustrine, hydrologic, and biogeographic evidence of late Neoglacial climate change in nonglacial areas of the Western United States

[ka, kilo-annum, thousands of years before present (B.P., 1950), unless otherwise indicated; , approximate; late Neoglacial refers to the Little Ice Age, a glacial period that occurred approximately 0.5 to $0.1 \mathrm{ka}]$

\begin{tabular}{|c|c|c|}
\hline Period & Description of change & Reference \\
\hline $0.39 \mathrm{ka}$ & $\begin{array}{l}\text { A shallow perennial lake occupied Silver Lake Basin at the terminus of the } \\
\text { Mojave River in southeastern California for several decades about } 390 \pm 90 \\
\text { radiocarbon years ago (dates from lake and shore deposits). The lake was pro- } \\
\text { duced by an increase in the frequency of winter storms in the Southwestern } \\
\text { United States. }\end{array}$ & $\begin{array}{l}\text { Enzel and others } \\
\qquad(1989 ; 1992)\end{array}$ \\
\hline $0.5-0.3 \mathrm{ka}$ & $\begin{array}{l}\text { Two lake-level highstands, separated by a lowstand, occurred in the Mono Lake } \\
\text { Basin of eastern California from } 500 \text { to } 300 \text { calibrated radiocarbon years B.P. } \\
(1450-1650) \text {. }\end{array}$ & Stine (1990) \\
\hline $0.6-0.1 \mathrm{ka}$ & $\begin{array}{l}\text { Alberta Lakes, North Dakota. A return to high-water conditions occurred follow- } \\
\text { ing low-water stands caused by the droughts of the Medieval Warm Period } \\
(0.95-0.65 \mathrm{ka}) \text {. }\end{array}$ & Vance and others (1992) \\
\hline$-0.55-0.35 \mathrm{ka}$ & $\begin{array}{l}\text { Large floods occurred in central Arizona and southern Utah. The floods may have } \\
\text { been related to a high frequency of North Pacific sea-level pressure patterns } \\
\text { that occurred during the early } 1600 \text { 's. }\end{array}$ & $\begin{array}{l}\text { Fritts and others (1979); } \\
\text { Ely and Baker (1990) }\end{array}$ \\
\hline$-0.4-0.3 \mathrm{ka}$ & $\begin{array}{l}\text { Frequent rains and associated high-magnitude streamflows occurred in southern } \\
\text { and central California during Little Ice Age advances in the Sierra Nevada. } \\
\text { The events are determined from tree-ring chronologies. The largest, positive } \\
\text { tree-ring-width anomaly coincides with the late Holocene Silver Lake trans- } \\
\text { gression in southern California, a period Enzel and others (1992) infer to be the } \\
\text { result of high-frequency runoff on the Mojave River. }\end{array}$ & $\begin{array}{l}\text { Schulman (1947); } \\
\text { Michaelsen and } \\
\text { Haston (1988) }\end{array}$ \\
\hline$\sim 0.52-0.10 \mathrm{ka}$ & $\begin{array}{l}\text { Tree-ring records from moisture-sensitive coniferous sites in New Mexico and } \\
\text { southern Colorado indicate above-normal wetness coincident with El Nino- } \\
\text { Southern Oscillation events during this time. Wet periods occurred } 1429-40 \text {, } \\
1487-98,1609-23 \text {, and } 1835-49 \text {. Decadal-scale droughts occurred about } 0.73 \text {, } \\
0.36,0.17 \text {, and } 0.05 \mathrm{ka} \text {. }\end{array}$ & $\begin{array}{l}\text { D'Arrigo and } \\
\text { Jacoby (1991) }\end{array}$ \\
\hline $0.515-0.155 \mathrm{ka}$ & $\begin{array}{l}\text { A downward shift in vegetation communities occurred in the northern Mojave } \\
\text { Desert, California, during this period. }\end{array}$ & Cole and Webb (1985) \\
\hline $0.4-0.3 \mathrm{ka}$ & $\begin{array}{l}\text { Episodes of marsh growth occurred in Panamint Valley, California, during this } \\
\text { period. Peat bogs were dated to about } 1550 .\end{array}$ & $\begin{array}{l}\text { Mehringer and } \\
\text { Warren (1976) }\end{array}$ \\
\hline Late Neoglacial & $\begin{array}{l}\text { Tree-line changes in the White Mountains of eastern California occurred during } \\
\text { this time in response to late Neoglacial climate fluctuations. }\end{array}$ & LaMarche (1974) \\
\hline
\end{tabular}

and direct precipitation, and that lake desiccation occurs in late spring to early summer when runoff ceases and evaporation rapidly increases. Because the rate of lake evaporation increases linearly compared to the surface area of a lake (Brakenridge, 1978), and because modern lakes in Death Valley reach their maximum size in late winter to early spring as temperature and evaporation begin to rapidly increase (fig. 20), seasonal changes in evaporation will effectively control the size and longevity of a closed-basin lake in Death Valley.

From these conditions, a lake-water-budget equation for closed-basin lakes in Death Valley can be developed. First, the equation must account for the formation of a modern lake, $R+P=L$ (where $R$ is the cumulative volume of runoff from the watershed catchment, $\mathrm{P}$ is the volume of direct precipitation, and $\mathrm{L}$ is lake volume). Second, the equation must account for lake desiccation (or longevity), $\mathrm{L}=\mathrm{E}$ (where lake volume, $L$, is consumed by evaporation, $E$, over a particular period of time). Combining these equations gives the simple closed-basin, lake-water-budget equation, $\mathrm{R}+\mathrm{P}=\mathrm{E}$.

This lake-water-budget equation is similar to the equations used by Enzel (1992); Brakenridge (1978), Snyder and Langbein (1962), and Broecker and Orr (1958) to evaluate the hydroclimatology of late Quaternary, closed-basin lakes in the Western United States. From Snyder and Langbein's (1962) study of the requisite precipitation runoff for a perennial, late Pleistocene lake in Spring Valley, Nevada, they concluded that the 


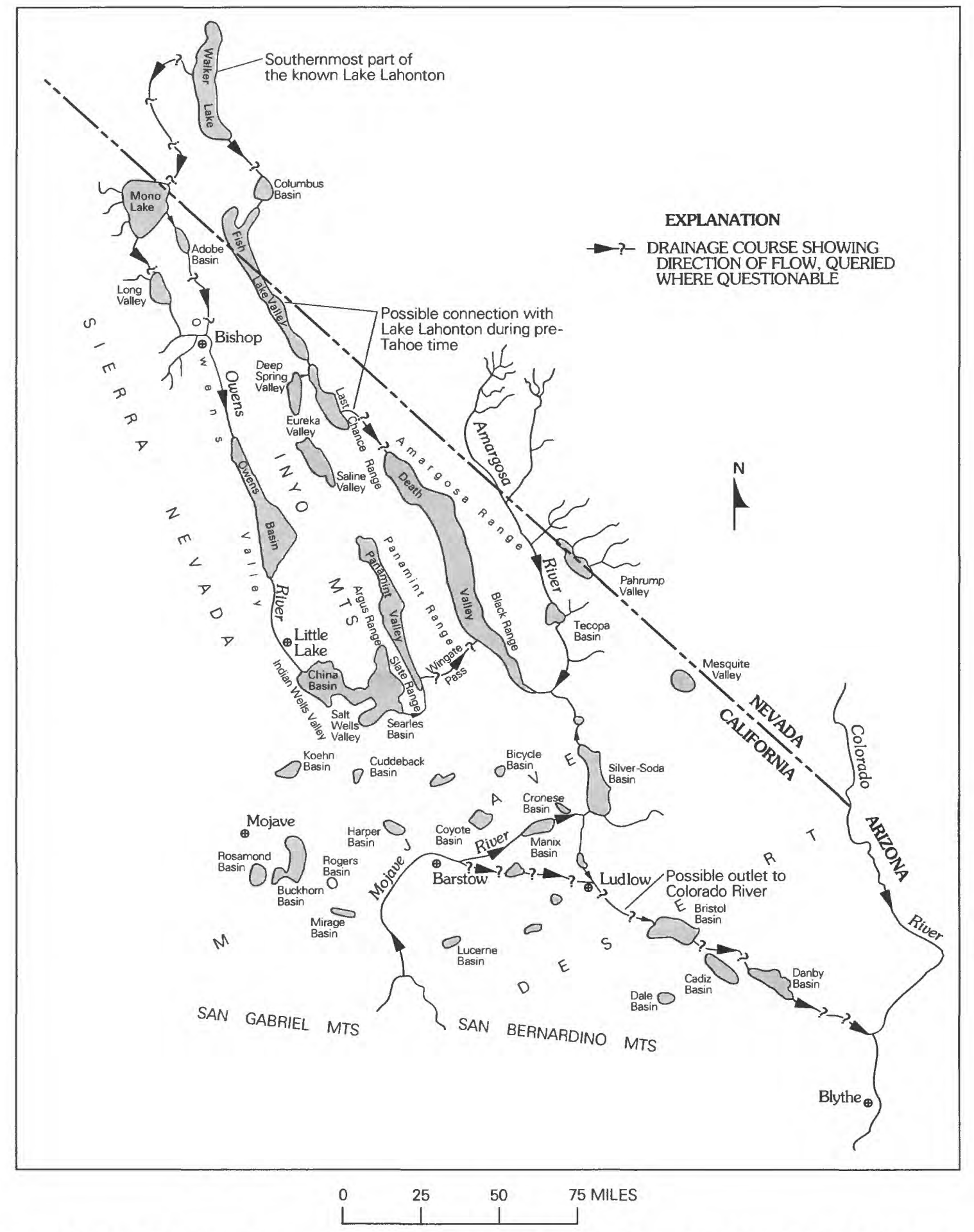

Figure 19. Late Pleistocene freshwater lakes and rivers in the southern Great Basin and Mojave Desert areas of Nevada and California. The proposed drainage routes that may have once connected the lake basins are shown (modified from Oakeshott, 1971, fig. 17-13, p. 323). 


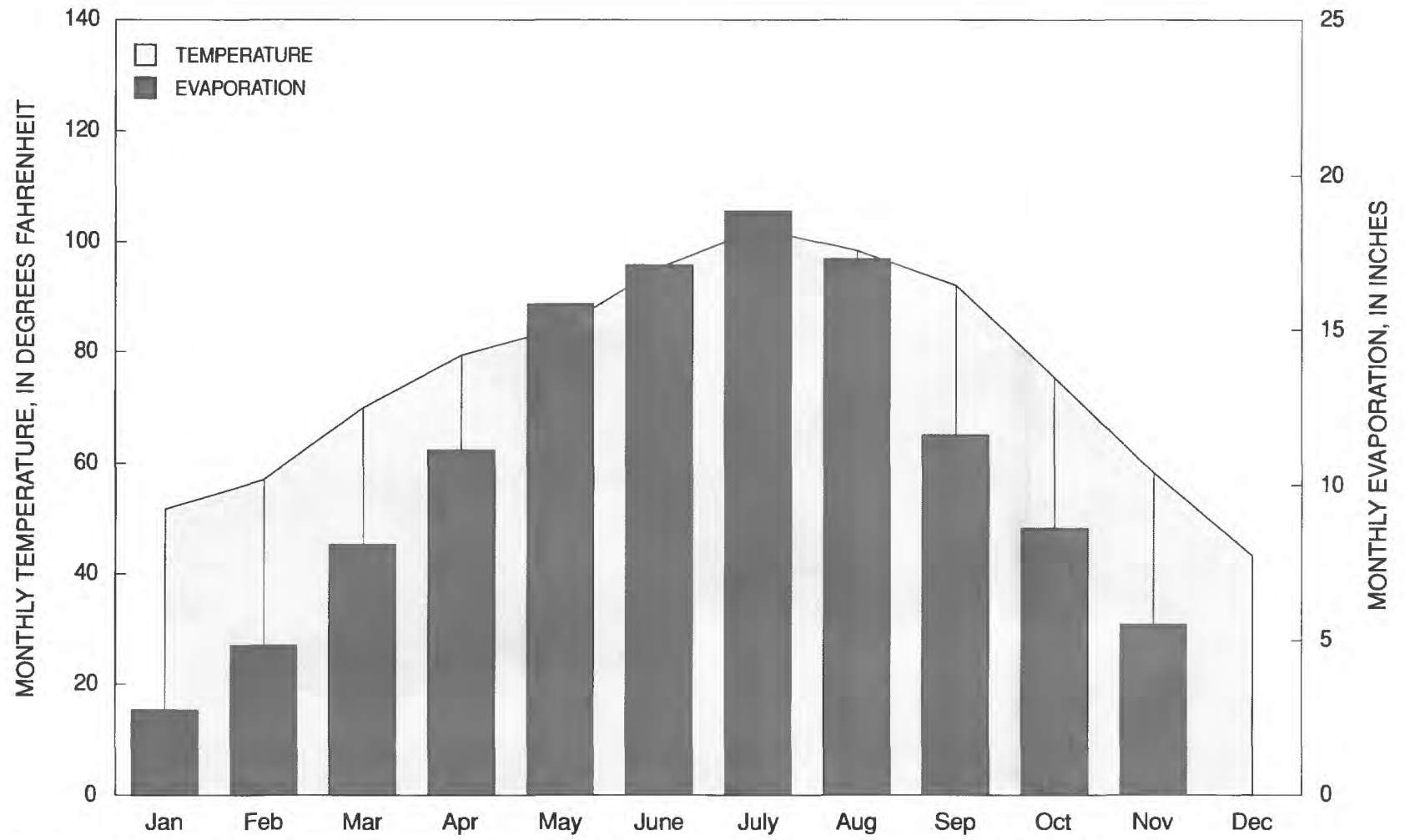

Figure 20. Monthly evaporation and average monthly temperature recorded in Death Valley, 1990.

average water loss from a lake basin must equal the combined runoff to the lake from its tributary (catchment) area. Similarly, Brakenridge (1978, p. 33) reported that, “. . . this [water-budget] equation must always be satisfied if the basins are hydrologically closed, and if lake and groundwater levels are stable." The equations used by these researchers were similar in that they assumed that input from, or output to, the water table did not occur or, as Brakenridge (1978, p. 33) contends, that the water table was in a state of quasi-equilibrium. However, if input from and output to the water table are included, the lake-water-budget equation becomes, $\mathrm{R}+\mathrm{P}+\mathrm{U}=\mathrm{E}+\mathrm{O}$ (where underflow, $\mathrm{U}$, accounts for such ground-water inputs as interflow and base flow; and outflow, $\mathrm{O}$, accounts for water losses by seepage to the water table).

A final modification of this equation, as used to simulate lacustrine conditions in the Death Valley watershed, was adopted from Enzel (1992). In his evaluation of the hydroclimatic conditions of modern ephemeral and late Holocene perennial lakes in the Silver-Soda Lake Basin, Enzel (1992) separated runoff into two input components, flood runoff $(F)$ from the predominant contributing drainage basin, the Mojave River, and local runoff from tributary basins that drain directly into the lake basin.

The input and output components of the lakewater-budget equation for the Death Valley watershed are shown schematically in figure 21 . This equation $(\mathrm{F}+\mathrm{R}+\mathrm{P}+\mathrm{U}=\mathrm{E}+\mathrm{O})$ is based on the hydrologic balance of a lake (Smith and Anderson, 1982; Smith and Street-Perrott, 1983; Bradley, 1985), and accounts for such lake-water inputs as runoff from the upper and lower Amargosa River Basins (F), runoff from Salt Creek Basin and west and east alluvial fans (R), direct precipitation that falls onto the saltpan or lake surface $(\mathrm{P})$, and underflow from ground-water sources (U). The equation is balanced by the lake-water outputs, lake evaporation $(E)$ and outflow by seepage to the water table $(\mathrm{O})$. Although seepage to the water table (O) is shown as a possible output route for lake water in figure 21 , outflow from the lake to the water table was not included in the closed-basin lake simulations of Death Valley lakes because (1) the modern Death Valley saltpan has been shown to be a ground-water discharging playa (Hunt, 1966), (2) the water table 
beneath the saltpan may have been at a higher elevation (dashed line), and therefore, a larger contributor of lake water during the late Holocene (Hunt, 1966; 1975; Winograd and Szabo, 1985), and (3) evaporation from the surface of closed-basin lakes in Death Valley is a dominant mechanism for lake-water losses (table 8). Outflow to the water table from the catchment is also not included in the closed-basin, lake-water-budget equation because the methods used to compute surfacewater runoff from contributing drainage basins of the Death Valley watershed catchment (F and $R$ ) accounts for these losses.

\section{Application of the Lake-Water-Budget Equation}

Application of the lake-water-budget equation to the Death Valley watershed indicates that a shallow, ephemeral lake can be produced under the modern hydroclimatic regime of the area, but that a perennial lake can not be maintained. For example, if cumulative runoff $(F+R)$ from the watershed was $1,000 \mathrm{ft}^{3} / \mathrm{s}$ (about 2,000 acre-ft/d), it would take 25 days of sustained runoff to produce a lake having the volume of the winter 1969 lake, which was estimated by Hunt $(1975$, p. 15$)$ to contain about 50,000 acre-ft of water. Additionally, if one-half of this volume was produced by direct precipitation (for example, 2 in. of rainfall over the 223- $\mathrm{mi}^{2}$ saltpan for a total of 23,787 acre-ft), this same lake could form in less than 2 weeks. The problem is that an unusually large amount of water would be needed to maintain this hypothetical lake as a perennial lake and considering the potential 82 in. of annual lake evaporation in the valley (table 8). Under these conditions, a perennial lake the size of the winter 1969 lake, which was estimated by Hunt (1975, p. 15) to have a surface area of about 51,200 acres, could potentially lose about $6.8 \mathrm{ft}(350,000$ acre-ft) of water to evaporation annually, about seven times its volume. For this reason, the modern hydroclimatology of the Death Valley watershed does not promote the existence of a perennial lake in the valley.

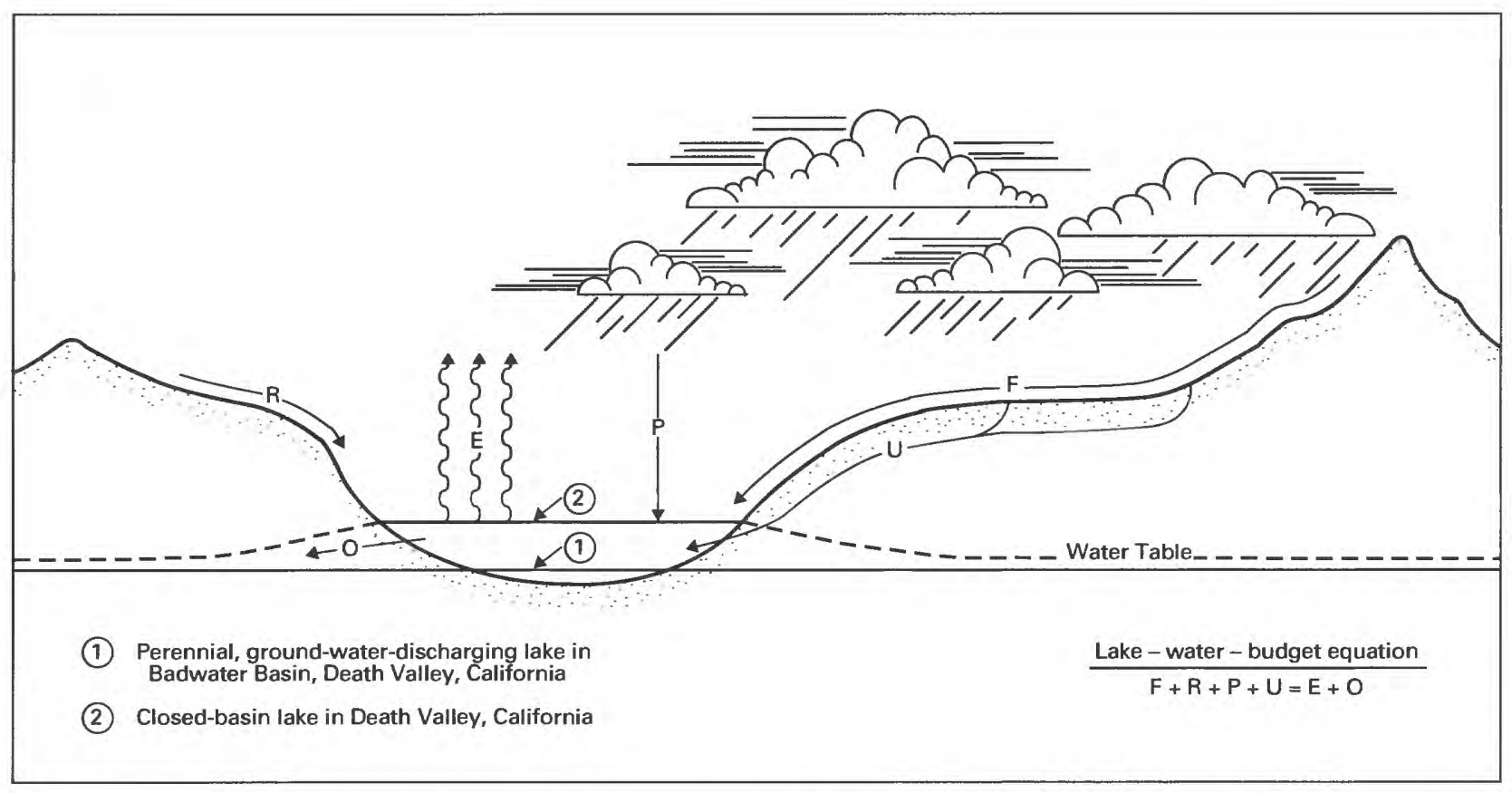

Figure 21. Diagrammatic sketch of the Death Valley watershed showing input and output sources of lake water. Letters refer to the lake-water-budget equation: $E$, lake evaporation; $F$, flood runoff; $O$, outflow to the unsaturated and saturated zones; $\mathrm{P}$, direct precipitation; $\mathrm{R}$, local runoff; $\mathrm{U}$, underflow as interflow and base flow. The modern water table is represented by the solid horizontal line, and the late Holocene water table is represented by a dashed line. 
Table 8. Annual evaporation from ephemeral and perennial lakes and reservoirs in southeastern California and southern Nevada

\begin{tabular}{llcc}
\hline \multicolumn{1}{c}{ Location } & \multicolumn{1}{c}{ Reference } & Period of record & $\begin{array}{c}\text { Annual evaporation } \\
\text { (inches) }\end{array}$ \\
\hline Death Valley & Hunt and others (1966) & $1961-63$ & $174.7-89.6$ \\
Death Valley & Meyers (1962) & $1946-55$ & $282.0-86.0$ \\
Silver Lake & Blaney (1957) & $1938-39$ & 379.9 \\
Salton Sea & Meyers (1962) & $1946-55$ & 280.0 \\
Salton Sea & Hughes (1967) & $1961-62$ & 471.6 \\
& & Nevada & \\
Lake Mead & Meyers (1962) & $1946-55$ & 282.0 \\
Havasu Lake & Meyers (1962) & $1946-55$ & 286.0 \\
Lake Mohave & Meyers (1962) & $1946-55$ & 284.0 \\
\hline
\end{tabular}

\footnotetext{
${ }^{1}$ Hunt and others (1966) measured monthly and annual evaporation rates in Death Valley from May 1958 to April 1961. Their uncorrected annual evaporation rate of 149.23 inches was adjusted using two pan-evaporation coefficients: 0.50 , derived by Hughes (1967) for the Salton Sea, California; and 0.60, reported by Meyers (1962). Average monthly evaporation in Death Valley ranges from 3.21 inches in January to 22.14 inches in August.

${ }^{2}$ Meyers (1962) used Class A pan-evaporation measurements and applied pan-evaporation coefficients to determine the regional evaporation rates of 17 Western States, 1946-55. Pan coefficients were computed using measured lake and pan evaporation rates. Meyers' map (1962, pl. 3) shows an average annual lake evaporation of 82 to 86 inches for much of southeastern California.

${ }^{3}$ Blaney (1957), using field evaporation pans, measured monthly and annual lake-evaporation rates for an ephemeral lake that inundated the Silver Lake playa for 18 months in 1938-39.

${ }^{4}$ Hughes (1967) used four different methods to derive evaporation rates for the Salton Sea, California. The annual evaporation rate reported in this table was derived using the mass-transfer approach for 1962 . The three other methods produce annual evaporation rates of 71.11 inches (energy budget), 70.29 inches (water budget), and 143.81 inches (uncorrected Class A pan). An annual pan coefficient of 0.50 (that is, the ratio of evaporation from the Salton Sea to pan evaporation) was derived based on the results of the energy-budget and water-budget methods for the period of record (1961-62).
}

\section{Water Budget of the Winter 1969 Lake}

The largest reported modern lake to inundate the Death Valley saltpan formed in the winter of 1969 following the second largest magnitude flood recorded on the Amargosa River at Tecopa, California, 1962-83 (table 3). In late February 1969, the Amargosa River discharged into Death Valley at a rate of about $750 \mathrm{ft}^{3} / \mathrm{s}$ (1,500 acre-ft/d) (Hunt, 1975, p. 15) and reached a peak discharge of $5,000 \mathrm{ft}^{3} / \mathrm{s}$ on February 26 at Tecopa (table 4). This storm, and other regionwide winter storms in late January, February, and early March produced a shallow lake that covered about $80 \mathrm{mi}^{2}$ $(51,200$ acres) of the Death Valley saltpan (Hunt, 1975, p. 15).
The lake-water-budget equation was applied to the winter 1969 lake to assess the regional relations between the lake-water inputs and outputs operating within the Death Valley watershed and to verify that this equation can accurately account for the formation and desiccation of a closed-basin lake in Death Valley. Recorded runoff data for the upper Amargosa River Basin and the estimated volume of precipitation over each drainage basin of the watershed (fig. 22) were used to establish surface-water input parameters for the simulation. These precipitation-runoff parameters established: (1) the volume of runoff and a runoff-torainfall ratio for the upper Amargosa River Basin, (2) the estimated volume of runoff contributed by 

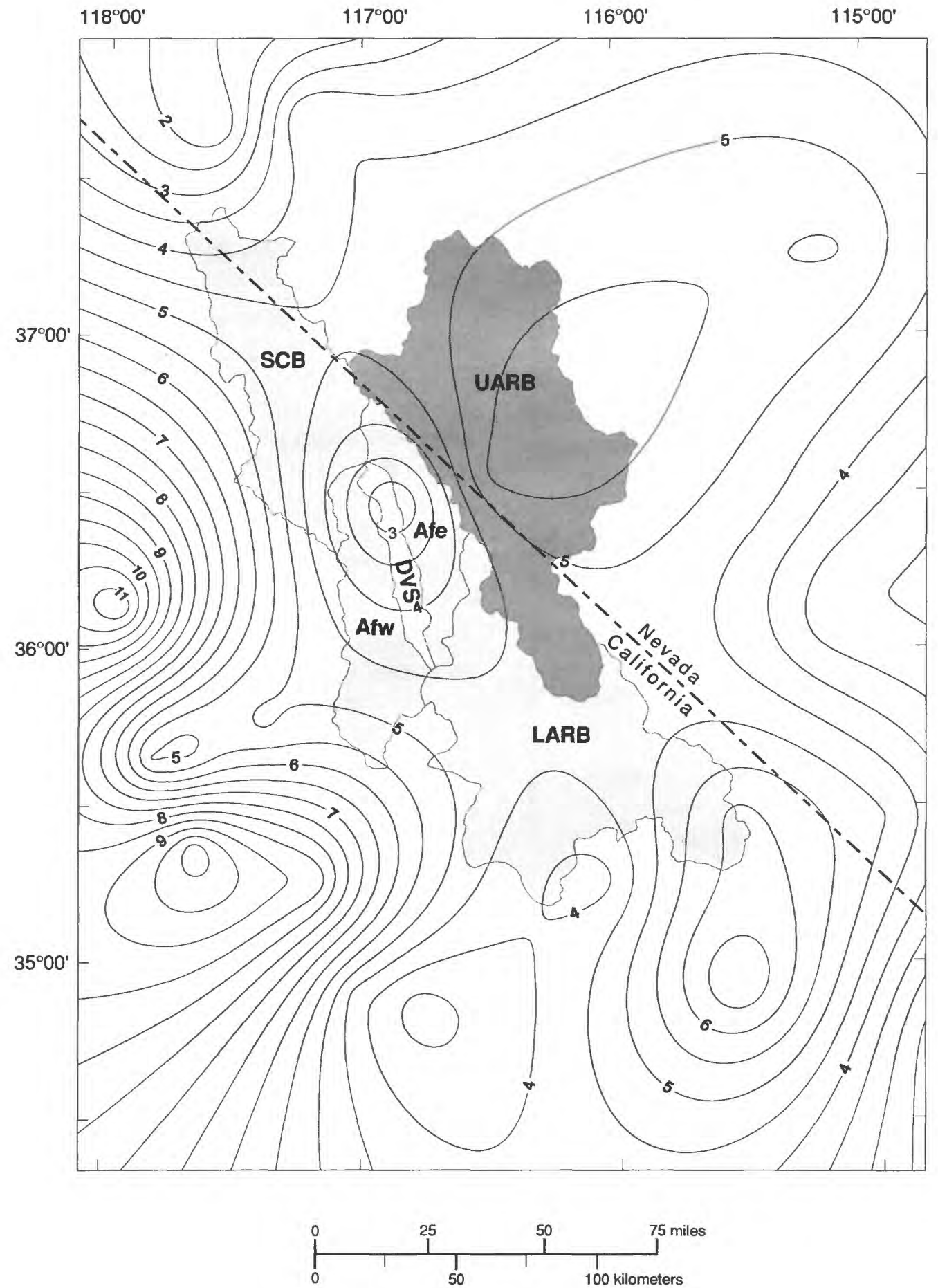

Figure 22. The distribution of winter 1969 precipitation over the Death Valley watershed in southern Nevada and southeastern California. Figure 6 shows the location of NOAA and NTS weather stations used for contouring. 
ungaged drainage basins in the watershed, and (3) the estimated volume of direct precipitation that may have been contributed to the winter 1969 lake. The cumulative contributions of surface water from runoff $(F+R)$, precipitation (P), and underflow (U) from major spring discharge areas in the watershed were then compared with the volume of the winter 1969 lake (L) to determine whether this lake could have been produced by these watershed sources (that is, whether the lakewater-budget equation, $F+R+P+U=L$, would balance). Finally, the effects of lake evaporation (E) were evaluated to identify the longevity of the lake (that is, whether the volume of the lake could be consumed by evaporation, $\mathrm{L}=\mathrm{E}$, within the reported length of time).

The results of the winter 1969 lake-water-budget simulation are given in table 9. The simulation indicates that this lake was produced by a combination of flood runoff from the Amargosa River (F), local runoff from Salt Creek Basin and alluvial-fan drainage basins $(R)$, direct precipitation (P), and underflow (U) from major spring discharge areas along the Amargosa River $\left(\mathrm{U}_{\mathrm{cf}}\right)$ and in Death Valley $\left(\mathrm{U}_{\mathrm{wt}}\right)$. Most importantly, the simulation indicates that no single source of water was responsible for the winter 1969 lake, but that abovenormal, precipitation-runoff from slow-moving storms over the watershed, sustained discharge from springs, and low winter evaporation were, together, effective in producing the lake.

As expected, the upper Amargosa River Basin contributed the largest runoff volume despite its relatively low runoff-to-rainfall ratio because of its large catchment size and location in the wettest part of the watershed (fig. 22). A runoff-to-rainfall ratio (runoff percent) of 0.8 percent was derived for the upper Amargosa River Basin using the estimated volume of precipitation received by the basin (rounded to the nearest 1,000 acre- $\mathrm{ft}$ ) and the volume of runoff recorded at Tecopa, California. Runoff volumes for other ungaged basins of the Death Valley watershed were derived using interpolated rainfall volumes over their respective drainage basins (fig. 22) and estimated runoff-torainfall ratios. Ratios of $1.0,1.5$, and 2.0 percent were used for the lower Amargosa River Basin, Salt Creek Basin, and alluvial fan drainage basins (table 9). The estimated runoff-to-rainfall ratios used in these computations were based on onsite investigations, the results of precipitation-runoff analyses of storms over the upper Amargosa River Basin (this report), and the results of runoff investigations of arid drainage basins in the Sahara Desert by Schick (1988, p. 193-194). In general, runoff values of 2 percent or less are relatively low compared to reported runoff-to-rainfall ratios of more than 5 percent for different magnitude storms, and 40 to 75 percent for drainages underlain by late Holocene alluvium in desert areas (Schick, 1988, p. 194). One explanation for this low runoff-to-rainfall ratio of the upper Amargosa River Basin (0.8 percent) is that, for more than one-half of its distance to Tecopa, the Amargosa River flows within a broad, braided stream channel across an expansive flat-lying area underlain by permeable, late Quaternary alluvium, eolian sands, and lacustrine deposits in the Amargosa Desert, where evaporation and seepage can consume vast amounts of surface water. Variations that do occur in the runoff-to-rainfall ratio of the basin were found to be related to storm intensity and magnitude. For example, the highest runoff-to-rainfall ratios (1.3 and 1.8 percent) were produced by late-summer thunderstorms in August 1983 and by storms related to the passage of Hurricanes Kathleen and Liza in September and October 1976. These storms produced some of the largest recorded floods on the Amargosa River (table 3).

An unexpected result of the winter 1969 lake simulation was the potential volume of water from direct precipitation (P) and underflow (U). For the simulation, 50 percent of the interpolated volume of precipitation over the saltpan and 3 months ( 90 days) of sustained spring discharge were used to assess the potential contributions of surface water from these sources. Although the volume of rainfall over the saltpan can be estimated, the volume of water that may have been lost to evaporation prior to it reaching the lake is unknown. Also, because there is no accurate measure for accounting for the contribution of ground water from springs in the watershed, recorded daily discharge measurements from the largest perennially flowing springs in the upper and lower Amargosa River Basins (Bedinger and others, 1989, pl. 5) and in Death Valley (Hunt and others, 1966, table 25, p. B38) were used to account for these ground-water sources. The contribution of water from these source areas was 67 and 36 acre- $\mathrm{ft} / \mathrm{d}$ for a total contribution of 6,020 and 3,220 acre-ft for the 3-month period (table 9). When compared to the 1,500 acre-ft/d runoff on the Amargosa River in February 1969, these spring discharge measurements seem meager, but the continuously flowing springs may have contributed more than 
Table 9. Lake-water budget and hydroclimatic parameters of the winter 1969 lake in Death Valley, California

$\left[\mathrm{mi}^{2}\right.$, square mile; acre-ft, acre-feet; in., inches; acre-ft/mi ${ }^{2}$, acre-feet per square mile; F, runoff on the Amargosa River at Tecopa, California; $R$, runoff from Salt Creek Basin and alluvial fan drainage basins; $P$, direct precipitation; $U_{\mathrm{cf}}$ and $\mathrm{U}_{\mathrm{wt}}$, interflow and baseflow from spring discharge areas; $\mathrm{E}$, lake evaporation; ---, not applicable]

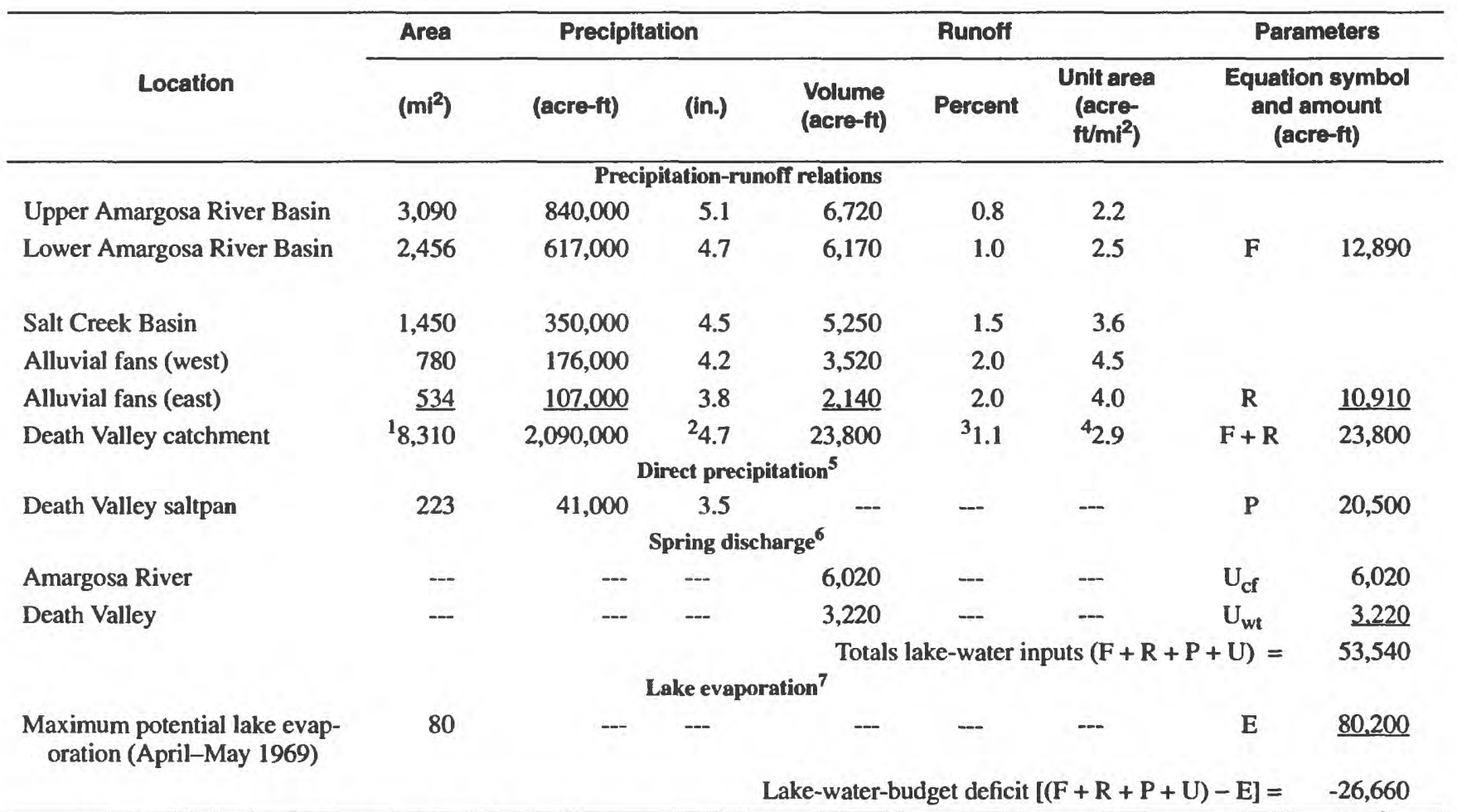

\footnotetext{
${ }^{1}$ Total area of the Death Valley watershed catchment, excluding the Death Valley saltpan.

${ }^{2}$ Precipitation in inches over the Death Valley watershed catchment was computed as: precipitation (acre-ft)/area (acres) $\times 12$.

${ }^{3}$ Percent runoff (that is, the volume of runoff as a percentage of total precipitation over the Death Valley catchment) was computed as: runoff
} (acre-ft)/precipitation (acre-ft) $\times 100$. This computation accounts for the volume of precipitation that was lost to evaporation, transpiration by plants, and seepage to the unsaturated and saturated zones of the water table.

${ }^{4}$ Average runoff per unit area for the Death Valley watershed catchment was computed as: runoff (acre-ft)/area $\left(\mathrm{mi}^{2}\right)$.

${ }^{5}$ Amount of precipitation that fell directly on the Death Valley saltpan and the winter 1969 lake as it increased in size (surface area). Fifty percent of this rainfall is estimated to have been contributed to the winter 1969 lake.

${ }^{6}$ Underflow as interflow $\left(\mathrm{U}_{\mathrm{cf}}\right)$ was tabulated from reported measurements made by Bedinger and others (1989, plate 5) along the Amargosa River in the Amargosa Valley (Ash Meadows) area, Shoshone and Tecopa areas, and along the lower Amargosa River in southern Nevada and southeastern California. Underflow as base flow $\left(\mathrm{U}_{\mathrm{wt}}\right)$ was tabulated from reported measurements made in Death Valley, California, by Hunt and others (1966, table 25, p. B38) at major spring discharge areas surrounding the Death Valley saltpan (east side of Cottonball Basin-Furnace Creek Wash areas; west sides of Badwater and Middle Basins; west side of Cottonball Basin, Salt Creek, and Cottonball Marsh; and east sides of Badwater and Middle Basins). Discharge rates given are for 3 months (January-March) based on average daily flow measurements. Although many of the springs in Death Valley contribute water to the saltpan as interflow $\left(U_{c f}\right)$, all of the spring-discharging water in Death Valley was tabulated as base flow $\left(U_{w t}\right)$ because of the close proximity of the springs to the Death Valley saltpan. Only the largest perennial springs with recorded discharge rates were used.

${ }^{7}$ Lake evaporation is based on a lake of 80 square miles ( 51,200 acres) in size and is the estimated amount of water (in acre-feet) that could have potentially evaporated during April and May, after the lake was formed. The total, 2-month, potential evaporation for the period was 31.3 inches, based on Class A pan measurements made by Hunt (1966). A pan coefficient of 0.6 was used to derive the 18.8 inches of lake evaporation used in the computation. This is a maximum value because, as the lake evaporated, its surface area would have decreased in size, thus decreasing the amount of evaporation. 
15 percent of the total volume of water contained by the winter 1969 lake (table 9).

Like other modern ephemeral lakes that have formed in Death Valley, the winter 1969 lake was shortlived. The simulation indicates that evaporation could have decreased the volume of the $80-\mathrm{mi}^{2}$ lake by more than 80,000 acre-ft in just 2 months (April and May) resulting in a lake-water-budget deficit of $-26,660$ acre-ft for the winter 1969 lake-forming event (table 9). Although the simulation is consistent with the demise of the winter 1993 lake, which was observed by the author to decline to the level of small disconnected ponds in just 5 weeks, the actual rate of evaporation from the winter 1969 lake could not be accurately computed because as the lake dried, its surface area diminished and the rate of evaporation also diminished. Moreover, because ephemeral lakes in Death Valley dissolve salts (for example, sodium chloride) that are abundantly present on the surface of the Death Valley saltpan (Hunt and others, 1966), these lakes become increasingly saline as they diminish in volume and will eventually become saturated brines. The net result of this rapid increase in salinity is decreased evaporation. Harbeck (1955) reported that, in saturated brines dominated by sodium and potassium, evaporation rates were decreased by 60 to 80 percent compared to the evaporation rates of freshwater lakes. In support of this finding, Hunt (1975, fig. 7, p. 17) reports that standing water of the winter 1969 lake lasted well into the summer, despite the high rate of evaporation in Death Valley.

\section{Late Holocene Lakes}

Hunt (1966, p. A82; 1975, p. 15) reported the prior existence of a large perennial lake in Death Valley between about 2 and $5 \mathrm{ka}$ ( 1 A.D. to 3,000 B.C.). The minimum age of this lake was determined from human artifacts of the prehistoric Death Valley IV (pottery) occupation (about 1,000 A.D.) and Death Valley III (pre-pottery, bow-and-arrow) occupation (about 1 A.D.) that were recovered from sand dunes that bury parts of the paleolake bed west of Badwater Basin in Death Valley, California. From remnant shorelines of this lake in Death Valley, Hunt $(1975$, p. 15) estimated that the late Holocene lake was 10 times as deep as the winter 1969 lake, that it covered at least 4 times as much surface area, and that its desiccation resulted in the formation of the Death Valley saltpan (fig. 2). On the basis of this lacustrine evidence, Hunt (1975) reasoned that the volume of water contained by the late Holocene lake must have been about 40 times more than the volume contained by the winter 1969 lake, or about 2,000,000 acre-ft. Hunt (1966, p. A82) also recognized that, subsequent to the desiccation of the late Holocene lake, tectonism has tilted the floor of Death Valley eastward so that the remnant shorelines of the lake are about $20 \mathrm{ft}$ lower on the east side of the valley (at an elevation of about $-260 \mathrm{ft}$ ) than they are on the west side of the valley (at an elevation of about $-240 \mathrm{ft}$ ) near Badwater Basin (fig. 2).

\section{Regional Hydroclimatic Conditions}

The formation of the late Holocene lake in Death Valley during a single winter season would have required nearly a 40 -fold increase in the volume of precipitation, runoff, and spring discharge from the watershed when compared to the winter 1969 lake event, or about forty consecutive storms the size of the February 1969 storm, which produced the 11.5-year recurrenceinterval flood on the Amargosa River at Tecopa, California (table 4). Because these hypothetical conditions would have been extreme for the period, different combinations of increased precipitation, runoff, and spring discharge were combined with decreased lake evaporation to simulate the hydroclimatology of a late Holocene perennial lake in Death Valley. The simulations assessed likely changes in climate and hydrology relative to the winter 1969 lake event within the range of conditions presented for the region during late Holocene Neoglacial periods (tables 6 and 7) and late Pleistocene pluvial periods (Snyder and Langbein, 1962; Mifflin and Wheat, 1979; Smith and StreetPerrott, 1983).

Evidence for late Holocene hydroclimatic change has been presented for nonglacial locations throughout the western United States (tables 6 and 7). This evidence indicates that cool, wet climatic conditions persisted during distinct time periods after about $4.8 \mathrm{ka}$ and that, during at least two periods of less than about 100 years in the early Neoglacial (4-3 ka) and in the late Neoglacial $(0.7-0.1 \mathrm{ka})$, climatic conditions may have been favorable for a perennial lake in Death Valley. For these late Holocene pluvial periods, Enzel (1992) reported that storms and floods with magnitudes comparable to the largest storms and floods of the modern record occurred more frequently (almost annually) on the Mojave River, and that these hydroclimatic 
conditions resulted in the formation and maintenance of perennial lakes for periods of less than about 100 years in the Silver-Soda Lake Basin at the terminus of the Mojave River. When compared to the modern flood record of the Mojave River, these floods have recurrence intervals longer than 18 years. The almost annual occurrence of these large floods during high lake-level stillstands at 3.6 and $0.39 \mathrm{ka}$ (tables 6 and 7) indicates that a different hydroclimatic regime dominated the region for at least short intervals of less than about a century during the late Holocene (McFadden and others, 1988; Brown and others, 1989; Enzel and others, 1989; Enzel, 1992; Enzel and others, 1992).

In the late Pleistocene, similar, but more intense, pluvial lake-forming conditions also have been well documented for the region. For example, between 25 and $15 \mathrm{ka}$, large pluvial lakes formed in closed basins throughout much of the Great Basin in response to cooler temperatures, increased precipitation-runoff, and decreased evaporation (Smith and Street-Perrott, 1983). Although the magnitude of these changes is uncertain, lake studies in Nevada, New Mexico, Oregon, and Texas indicate that annual temperature was 5.4 to $18.9^{\circ} \mathrm{F}$ colder, evaporation was 10 to 45 percent less, and that more precipitation was received by the hydrologic catchments of these lake basins when compared to modern hydroclimatic conditions during the late-Twentieth Century (Smith and Street-Perrott, 1983, table 10-1, p. 195). For southern Nevada, Mifflin and Wheat (1979) proposed that the late Pleistocene lakes south of about 37 degrees north latitude were paludal or playa lakes rather than pluvial lakes. However, this proposal contradicts the work of Snyder and Langbein (1962, p. 2392-2394) who reported that a $335-\mathrm{mi}^{2}$ pluvial lake could have been supported during the late Pleistocene in the Spring Valley of southern Nevada by an 8 -in. increase (that is, about a 70 - to 100 -percent increase) in precipitation, a 33-percent increase in runoff, and a 30-percent decrease in evaporation (that is, from about 44 to 31 in. annually, which they felt was obtainable by a $13^{\circ} \mathrm{F}$ decrease in summer temperature).

These late Quaternary pluvial events in the Great Basin are important for two reasons. First, they show that lakes have been produced in closed-basin locations throughout the region (fig. 19) as a result of increased precipitation and runoff and decreased temperature and evaporation. Second, they provide general boundary conditions for evaluating the hydroclimatology of a late Holocene perennial lake in Death Valley.

\section{Hydroclimatic Simulations for a Late Holocene Perennial Lake}

The formation of a late Holocene perennial lake in Death Valley would have required some combination of sustained, regional hydroclimatic change, such as an increase in precipitation, runoff, or spring discharge and a concomitant decrease in lake evaporation. For example, the lake could have been produced by a 30 - to $40-\mathrm{ft}$ rise in the water table beneath the Death Valley saltpan, thus raising the level of the groundwater-discharging pond at Badwater to the level of the late Holocene lake (fig. 21). Wetter conditions and a higher water table were proposed by Hunt (1966, p. A82) to account for the late Holocene lake in Death Valley. Also, Winograd and Szabo $(1985$, p. 7$)$ indicated that the water table in the south-central Great Basin has declined due to tectonism, climatic change, and erosion at a regional rate of about $0.07 \mathrm{ft} / 1,000$ years in the Ash Meadows area during the past 510,000 years and at rates an order of magnitude higher (about 0.7-2.0 ft/1,000 years) during the Quaternary in the Furnace Creek Wash area of east-central Death Valley. However, even at the maximum rate of decline, which is subject to considerable speculation for the late Holocene (2-5 ka), the water table in Death Valley would only have been about 4 to $10 \mathrm{ft}$ above its present (1995) level at Badwater Basin (that is, only about one-tenth to one-quarter the maximum depth of the late Holocene lake). Furthermore, this groundwater-fed lake in Death Valley would still have been subjected to intense summer evaporation without a decrease in temperature. Although the existence of such water table conditions should not be ruled out, other regional hydroclimatic factors that have been documented for the period (tables 6 and 7) may have been instrumental in producing the late Holocene lake in Death Valley.

To assess the magnitude of the hydroclimatic changes required to produce the late Holocene lake in Death Valley, different combinations of change relative to the winter 1969 lake period were used as input and output values for the closed-basin, lake-water-budget equation. The numerical simulations tested were: (1) Increases in runoff resulting from increases in precipitation and concomitant increases in the average runoff-to-rainfall ratio (percent runoff) for the watershed, (2) increases in direct precipitation, (3) increases in spring discharge, and (4) decreases in lake evaporation. Except for the ground-water inputs 
that may have resulted from simulated increases in spring discharge, no accounting was made for a higher late Holocene water table or for potential output losses due to seepage from the lake to the water table.

The results of these hydroclimatic simulations for a late Holocene perennial lake in Death Valley are listed in table 10. Simulations and lake-water budgets are presented for increases in runoff $(F+R)$ resulting from increases in precipitation of 10 to 200 percent and increases in the average runoff-to-rainfall ratio (percent runoff) for the watershed of 2 to 6 percent (compared to 1.1 percent for the winter 1969 lake period); increases in direct precipitation (P) of 10 to 200 percent; increases in spring discharge (U) of 10 to 200 percent; and decreases in annual lake evaporation of 10 to 50 percent (table 10). Increases in precipitation-runoff, direct precipitation, and spring discharge were calculated relative to the winter 1969 lake period (table 9). Decreases in lake evaporation were calculated relative to measurements made by Meyers (1962) and Hunt and others (1966) for Death Valley (table 8). An annual lake evaporation of $82 \mathrm{in}$. was used for the lake-water budgets listed in table 10 .

The simulations and lake-water budgets listed in table 10 indicate that large-scale hydroclimatic changes were needed to produce and maintain a late Holocene perennial lake in Death Valley. Discounting the effects of lake evaporation, for example, the lake-water-budget simulations indicate that the 2,000,000-acre-ft late Holocene lake could have been produced in 4 years by a sustained 200-percent increase in precipitation-runoff over the Death Valley watershed (that is, an average winter rainfall of about 13.4 in. compared to $4.5 \mathrm{in}$. in the winter of 1969); an increase in the average runoff-to-rainfall ratio (percent runoff) for the watershed from 1.1 percent in 1969 to 6.0 percent in late Holocene; and a 200 -percent increase in spring discharge (table 10). Together, these increases would have yielded about 526,760 acre-ft of water $(\mathrm{F}+\mathrm{R}+\mathrm{P}+\mathrm{U})$ during a single winter season (table 10) or 2,107,040 acre-ft in four years (that is, slightly more than the estimated volume of the late Holocene lake). However, when the effects of lake evaporation are considered, it becomes apparent that the late Holocene perennial lake could not have been maintained in Death Valley without at least a 50 -percent decrease in evaporation because with even a 40-percent decrease in evaporation, lake evaporation still could have potentially consumed about
585,000 acre-ft of water annually from the $223-\mathrm{mi}^{2}$ late Holocene lake (table 10).

The effects of a sustained 200-percent increase in lake-water inputs $(F+R+P+U)$, compared to the winter of 1969, and a sustained 40-percent decrease in annual evaporation (E) for a 35-year period are shown in figure 23 (solid line). This time-series computation of the hydroclimatic parameters presented in table 10 indicates that a late Holocene perennial lake could have grown rapidly to about $180 \mathrm{mi}^{2}$, but that it would not have surpassed about $200 \mathrm{mi}^{2}$ in surface area even after 35 years. Similarly, only small perennial lakes (about 120 and $140 \mathrm{mi}^{2}$ ) could have been produced in Death Valley by a 100 -percent increase in lake-water inputs and 40- and 50-percent decreases in annual lake evaporation (fig. 23). Only when annual lake evaporation was decreased from 40 percent (49.8 in.) to 50 percent (41.0 in.) could the $223-\mathrm{mi}^{2}$ late Holocene perennial lake be produced by a 200 -percent increase in lakewater inputs. This simulation indicates that these hydroclimatic conditions could have produced the late Holocene perennial lake in about 12 years and maintained it indefinitely (fig. 23). It should be noted, however, that the estimated amounts of lake water lost to evaporation in these simulations are maximum amounts because no accounting was made for the incremental decreases in lake evaporation that would have resulted from the incremental decreases in lake size as desiccation progressed, or for the effects of increased salinity as the lake's volume was diminished.

The hydroclimatic simulations listed in table 10 and shown in figure 23 indicate that a sustained tenfold increase in cumulative lake water inputs $(F+R+P+U)$, from 53,540 acre-ft in the winter of 1969 to 526,760 acre-ft in late Holocene, were needed to produce the late Holocene lake in Death Valley, and that a sustained 50-percent decrease in lake evaporation, from 82 to 41 in. annually, were needed to maintain this lake at the maximum late Holocene level. In terms of flood runoff, the upper Amargosa River Basin would need to produce about 151,000 acre-ft of runoff compared to the 6,720 acre-ft that it produced in the winter of 1969 (table 10). To produce this volume of runoff, large-magnitude floods comparable in size to the modern 100-year recurrence-interval flood, which was estimated to produce about 42,600-acre-ft of runoff on the Amargosa River at Tecopa (table 5), would 
Table 10. Hydroclimatic simulations and lake-water budgets for a late Holocene lake in Death Valley compared to the winter 1969 lake

[mi2, square mile; acre-ft, acre-feet; F, flood runoff; R, local runoff; P, direct precipitation; U, underflow; E, lake evaporation; ---, not applicable]

Upper Amargosa River Basin Lower Amargosa River Basin Salt Creek Basin

Alluvial fans (west)

Alluvial fans (east)

Subtotal for watershed $(F+R)$

Area of winter 1969 lake

Area of late Holocene lake

Subtotal for watershed

$(F+R+P)$

Amargosa Valley

Death Valley

Total for watershed

$(F+R+P+U)$

Area of winter 1969 lake

Area of late Holocene lake

$\begin{array}{ccc}\begin{array}{c}\text { Area } \\ \left(\mathrm{mi}^{2}\right)\end{array} & \text { Winter } 1969 & \text { Late Holocene perennial lake } \\ \text { lake } & \text { Volumes (acre-ft) }\end{array}$

\section{RUNOFE (F+R ${ }^{1}$}

Percentage increases in precipitation

\begin{tabular}{lllll}
\hline 10 & 25 & 50 & 100 & 200 \\
\hline
\end{tabular}

Average runoff-to-rainfall ratio (percent runoff) for the watershed

\begin{tabular}{|c|c|c|c|c|c|c|}
\hline & 11 & 2 & 3 & 4 & 5 & 6 \\
\hline 3,090 & 6,720 & 18,500 & 31,500 & 50,400 & 84,000 & 151,000 \\
\hline 2,456 & 6,170 & 13,600 & 23,100 & 37,000 & 61,700 & 111,000 \\
\hline 1,450 & 5,250 & 7,700 & 13,100 & 21,000 & 35,000 & 63,000 \\
\hline 780 & 3,520 & 3,870 & 6,600 & 10,600 & 17,600 & 31,700 \\
\hline 534 & 2.140 & 2.350 & 4,010 & 6.420 & 10.700 & 19.300 \\
\hline $8, \overline{310}$ & 23,800 & $4 \overline{46,020}$ & $\overline{78,310}$ & $12 \overline{5,420}$ & $20 \overline{09,000}$ & $37 \overline{76,000}$ \\
\hline
\end{tabular}

Percentage increases in precipitation

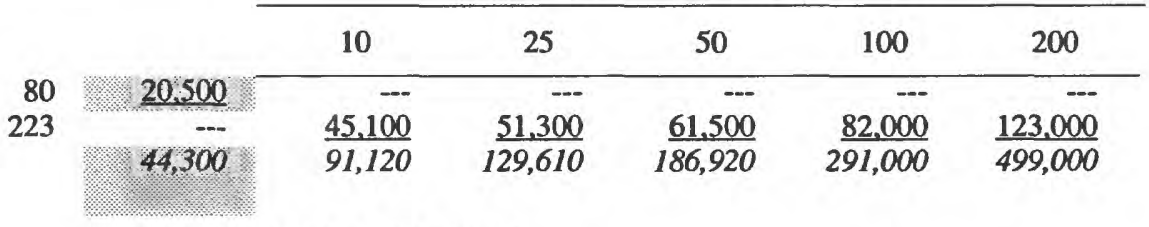

\section{SPRING DISCHARGE $(U)^{3}$}

Percentage increases in discharge

\begin{tabular}{|c|c|c|c|c|c|}
\hline & 10 & 25 & 50 & 100 & 200 \\
\hline 6,020 & 6,620 & 7,530 & 9,030 & 12,000 & 18,100 \\
\hline 3,220 & $\underline{3.540}$ & $\underline{4.030}$ & 4.830 & $\underline{6.440}$ & 2.660 \\
\hline 53,540 & 101,280 & 141,170 & 200,780 & 309,440 & 526,760 \\
\hline
\end{tabular}

\section{LAKE EVAPORATION (E) ${ }^{4}$}

Percentage decreases in evaporation

\begin{tabular}{|c|c|c|c|c|c|c|}
\hline & & 10 & 20 & 30 & 40 & 50 \\
\hline 80 & 80,200 & -- & -- & $\ldots$ & --- & -- \\
\hline 223 & - & $\underline{878,000}$ & $\underline{780,000}$ & $\underline{683,000}$ & $\$ 85,000$ & $\underline{488,000}$ \\
\hline & \multicolumn{6}{|c|}{$\frac{\text { LAKE-WATER BUDGET }^{5}}{\text { (acre-ft) }}$} \\
\hline & $-26,660$ & $-776,720$ & $-638,830$ & $-482,220$ & $-275,560$ & 38,760 \\
\hline
\end{tabular}

$[(\mathbf{F}+\mathbf{R}+\mathbf{P}+\mathbf{U})-\mathbf{E}]$

'Increases in runoff for the late Holocene lake simulations are listed as a function of both increases in precipitation (10 to 200 percent) and increases in the average runoff-to-rainfall ratio (percent runoff) for the watershed ( 2 to 6 percent). The average runoff-to-rainfall ratio (percent runoff) for the watershed was 1.1 percent during the winter 1969 lake period (table 9).

${ }^{2}$ Direct precipitation is the amount of water contributed to the $223-\mathrm{mi}^{2}$ late Holocene lake from the atmosphere. Increases (10 to 200 percent) were computed relative to the amount of precipitation (in inches) that was estimated to have fallen on the saltpan during the winter 1969 lake period.

${ }^{3}$ Increases in spring discharge (10 to 200 percent) were computed relative to the cumulative totals used for the winter 1969 lake-water budget.

${ }^{4}$ Decreases in lake evaporation (10 to 50 percent) were made for $223-\mathrm{mi}^{2}$ late Holocene lake using an annual evaporation rate of $82 \mathrm{in}$. (Meyers, 1962; Hunt and others, 1966). These are maximum annual amounts (in acre-ft) for the 223-mi lake.

${ }^{5}$ Lake-water budgets listed for the different late Holocene lake simulations are annual amounts. The winter 1969 lake-water budget is a seasonal amount. A negative water budget indicates that a perennial lake could not have been maintained in Death Valley. 


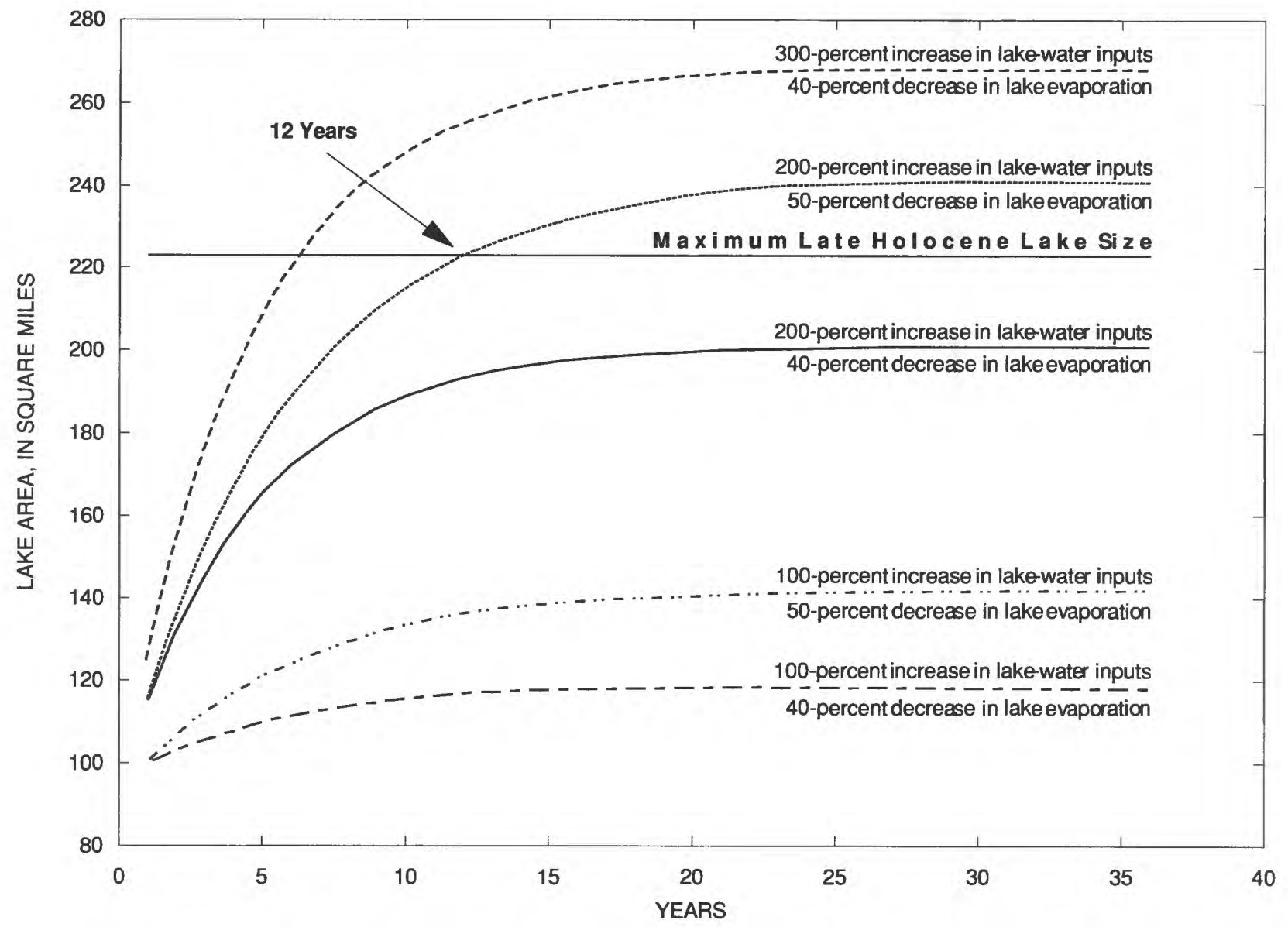

Figure 23. Different combinations of increased lake-water inputs (precipitation, runoff, and spring discharge) and decreased lake evaporation required to produce and maintain a late Holocene perennial lake in Death Valley.

have to occur three to four times per year from every drainage basin of the Death Valley watershed.

Another possibility is that the late Holocene lake formed as a result of more frequent winter storms and prolonged low-magnitude runoff from drainage basins of the Death Valley watershed. For example, Enzel (1992, p. 18) indicated that the late Holocene lake that inundated the nearby Silver Lake playa about $3.6 \mathrm{ka}$ was produced by frequent winter floods at a time when the average annual flood on the Mojave River was comparable in size to the modern 18-year recurrenceinterval flood. Furthermore, Ely and others (1993, p. 410) indicated that floods associated with moist climatic conditions and frequent El Nino events were most numerous between 4.8 and $3.6 \mathrm{ka}$, around $1 \mathrm{ka}$, and after $0.5 \mathrm{ka}$ in the Southwestern United States. For Death Valley, the 25-year recurrence-interval flood was estimated to yield about 43,250 acre-ft of runoff from the watershed (table 5). Therefore, to produce the
376,000 acre-ft of runoff, which was estimated by the 200 percent increase in precipitation and the 6 percent runoff-to-rainfall ratio for the watershed (table 10), would require nearly nine floods per year comparable in size to the modern 25-year recurrence-interval flood from drainage basins of the Death Valley watershed. For the Amargosa River, the 25-year flood was estimated by the results of the regional log-Pearson Type III analysis to have a peak discharge of about $12,000 \mathrm{ft}^{3} / \mathrm{s}$ at Tecopa, California (table 5), a flood slightly larger than the August 1983 flood that destroyed the gaging station at Tecopa (table 4).

The frequency and magnitude of late Holocene paleofloods in the Death Valley watershed may have been less for the lake-forming process if the water table beneath the Death Valley saltpan was at a higher elevation, even $10 \mathrm{ft}$ higher, than during the winter of 1969. A higher water table would have effectively decreased the volume of precipitation and runoff needed to 
produce the late Holocene lake in Death Valley, bringing the frequency and magnitude of floods closer to what Enzel (1992) indicated for the late Holocene lake that inundated the Silver Lake basin at the terminus of the Mojave River. Thus, a combination of a higher, late Holocene water table in Death Valley, as proposed by Hunt (1966) and suggested by Winograd and Szabo (1985), and more frequent large-magnitude floods that may have been related to moist climatic conditions and frequent El Nino events between 4.8 and $3.6 \mathrm{ka}$ in the region, as indicated by Enzel (1992) and Ely and others (1993), may have been sufficient to produce and maintain the late Holocene perennial lake in Death Valley.

Another possibility is that the climatic regime of the late Holocene did not support a perennial lake in Death Valley, but rather a series of large ephemeral lakes or short-lived perennial lakes that may have filled the valley for one or more years to the level of the late Holocene shorelines. Hydroclimatic conditions for these lakes may have been similar to those that formed the winter 1969 lake, although of considerably increased magnitude. Support for this hypothesis is provided by preliminary sedimentary evidence from the upper stratigraphy of a deep (about 1,600-ft) sediment core that was completed near the center of Badwater Basin in May 1993. The upper-most stratigraphy from this core indicated that a succession of short-lived, playa lakes inundated the Death Valley saltpan during the Holocene (no absolute chronological indicators were identified to subdivide the Holocene), rather than a single, longer-lived perennial lake (Steve Lund, University of Southern California, personal commun., 1993). The recurrence of deep-water ephemeral or short-lived perennial lakes in Death Valley during the Holocene would account for the bathtub ring of elevated paleolake shorelines seen in the valley today (fig. 1), and furthermore, would indicate that large-magnitude floods occurred more frequently within the Death Valley watershed during the late Holocene.

\section{SUMMARY AND CONCLUSIONS}

The closed-basin Death Valley watershed has been the site of large, shallow lakes during the Quaternary. In the late Holocene (2-5 ka) and during the modern period of record (1962-83 and 1992-1995), these lakes have formed in response to hydrologic changes within the closed-basin watershed. Modern lakes have formed during years of above-normal pre- cipitation and runoff, which have been generally related to the cyclic recurrence of the ENSO. From recorded precipitation, runoff, and spring discharge data for the winter 1969 lake-forming period in the Death Valley watershed, a closed-basin, lake-waterbudget equation was developed. The equation relates the volume of lake-water inputs (precipitation, runoff, and spring discharge) to the estimated volume of the lake, and the subsequent demise of the lake to the potential volume of water that may have evaporated from its surface during spring and early summer. Parameters from this analog model of a modern lakeforming period in the watershed were then used to assess the requisite hydroclimatology of a late Holocene perennial lake in the Death Valley watershed.

This study of the modern and late Holocene hydrology of the closed-basin Death Valley watershed evaluates the interactions between climate and surfacewater runoff, assesses the magnitude and recurrence intervals of floods, and presents hydroclimatic simulations for a large, late Holocene perennial lake in Death Valley. Hydrologic parameters for the severity and recurrence rates of floods on the Amargosa River, (the largest drainage in the watershed), are presented, and estimates of the magnitude of flood runoff from ungaged drainage basins in the watershed are made. On the basis of recorded hydroclimatic conditions for a modern lake period in the winter of 1969 , the likely hydrologic consequences of late Holocene climate changes, which have been reported on from the region, were identified for the $8,533-\mathrm{mi}^{2}$ Death Valley watershed.

Modern climatic and hydrologic data of the watershed indicate that above-normal precipitation and surface-water runoff are dynamically and cyclically related to lake transgressions in Death Valley. In wet years, which have been generally correlative with the ENSO, closed-basin lakes form in Death Valley as a result of increased winter precipitation-runoff and sustained spring discharge. The formation of modern lakes furnishes information about the nature and type of change that were required to produce a large perennial lake in Death Valley during the late Holocene (2-5 ka).

Rainfall-runoff parameters for a modern ephemeral lake in the winter of 1969 were developed using a closed-basin, lake-water-budget equation. Hydroclimatic conditions for the winters of 1969 and 1993, which were both exceptionally wet ENSO periods in 
the Southwestern United States, indicate that modern lakes form in late winter and quickly evaporate in spring to early summer. From these conditions, a lakewater-budget simulation for the winter 1969 lake in Death Valley was prepared. The simulation established: (1) The volumes of precipitation that fell over each drainage basin of the Death Valley watershed catchment and the Death Valley saltpan; (2) the recorded and estimated volumes of runoff from the upper Amargosa River Basin and ungaged drainage basins in the watershed; (3) the estimated volume of water from spring discharge areas along the Amargosa River and in Death Valley; and (4) the volume of lake water that can be potentially lost to evaporation.

The lake-water-budget simulation of the winter 1969 lake indicated that modern hydroclimatic conditions favor only the periodic existence of short-lived shallow lakes in Death Valley, and that these lakes form by a combination of above-normal streamflow from the Death Valley watershed catchment, precipitation that falls directly onto the saltpan and growing lake surface, and sustained spring discharge, which may contribute about 15 percent of the lake water. Hydroclimatic simulations for a late Holocene perennial lake in Death Valley indicated that this lake could have formed by a sustained 200-percent increase in precipitation, runoff, and spring discharge compared to the winter 1969 lake event, and by a 50-percent decrease in lake evaporation. Under these conditions, the $223-\mathrm{mi}^{2}$ late Holocene lake, which may have contained about $2,000,000$ acre-ft of water, could have been produced in about 12 years and sustained indefinitely.

Although it was estimated that the required annual runoff from the Death Valley watershed may have been about 376,000 acre-ft for the late Holocene lake, the frequency and magnitude of paleofloods in the watershed remains uncertain. For example, the late Holocene lake could have been produced in a single winter season by nine successive 25 -year recurrenceinterval floods from all of the drainage basins in the watershed, but such conditions are extreme. A second possibility is that unusually cool and wet climatic conditions, similar in intensity to the pluvial climatic conditions of the late Pleistocene, may have occurred during short periods of less than about 100 years in late Holocene, although evidence for such changes in climate has not been documented for the region. A third possibility is that the paleolake formed as a combined result of a slightly high water table, a more moderate increase in precipitation, runoff and spring discharge, and a modest decrease in evaporation. Favorable conditions for such changes have been documented for two periods of less than about $\mathbf{1 0 0}$ years during an early Neoglacial period (4-3 ka) and a late Neoglacial (0.7-0.1 ka) period; and paleoflood evidence has been presented for many late Holocene floods associated with moist climates and frequent El Nino events during three, late Holocene periods (4.8-3.6 ka, about $1 \mathrm{ka}$, and after $0.5 \mathrm{ka}$ ) in the Southwestern United States.

While the nature and timing of the requisite hydroclimatic changes for a late Holocene perennial lake in Death Valley remain uncertain, this study presents hydroclimatic scenarios for the production and maintenance of this lake and raises important questions regarding the frequency and magnitude of past floods and their chronological relationship to late Holocene regional climate change. Future work is needed to (1) identify the nature and timing of late Holocene paleolakes in Death Valley from the lacustrine sedimentary record of the Death Valley saltpan, (2) locate and evaluate reliable, late Holocene paleoflood data for the Amargosa River, (3) obtain quantitative runoff data of ungaged drainage basins in the watershed to further refine the numerical parameters of the closed-basin, lake-water-budget equation, and (4) correlate the late Holocene paleoflood hydrology of the Death Valley watershed, and especially the Amargosa River, with chronologically relevant paleoflood data documented for the Southwestern United States. This future research would help to refine the paleoflood hydrology of the region and provide further data for evaluating the hydrologic effects of regional climate changes in the Yucca Mountain site area.

\section{SELECTED REFERENCES}

Abtew, W., Obeysekera, J., and Shih, G., 1993, Spatial analysis for monthly rainfall in south Florida: Water Resources Bulletin, v. 29, no. 2, p. 179-188.

Andrews, J.T., Carrara, P.E., King, F.B., and Struckenrath, R., 1975, Holocene environmental changes in the alpine zone, northern San Juan Mountains, Colorado; evidence from bog stratigraphy and palynology: Quaternary Research, v. 5, no. 2, p. 173-197.

Antevs, E.V., 1948, The Great Basin, with emphasis on glacial and postglacial times-3, Climatic changes and pre-white man: University of Utah, Bulletin, v. 38, no. 20 , p. $168-191$. 
Bedinger, M.S., Sargent, K.A., and Langer, W.H., eds., 1989, Studies of geology and hydrology in the Basin and Range Province, Southwestern United States, for isolation of high-level radioactive waste; characterization of the Death Valley region, Nevada and California: U.S. Geological Survey Professional Paper 1370-F, 49 p., 8 plates.

Benedict, J.B., 1973, Chronology of cirque glaciation, Colorado Front Range: Quaternary Research, v. 3, no. 4, p. 584-589.

Benson, L.V., and Klieforth, Harold, 1989, Stable isotopes in precipitation and ground water in the Yucca Mountain region, southern Nevada; paleoclimatic implications, in Peterson, D.H., ed., Aspects of climate variability in the Pacific and the western Americas: American Geophysical Union, Geophysical Monograph 55, p. 41-59.

Benson, L.V., Meyers, P.A., and Spencer, R.J., 1991, Change in the size of Walker Lake during the past 5000 years: Palaeogeography, Palaeoclimatology, Palaeoecology, v. 81, no. 3-4, p. 189-214.

Benson, L.V., and Thompson, R.S., 1987, The physical record of lakes in the Great Basin, in Ruddiman, W.F., ed., North America and adjacent oceans during the last deglaciation, in the collection Geology of North America: Boulder, Colo., Geological Society of America k-3, p. 241-260.

Benson, M.A., 1962, Evolution of methods for evaluating the occurrence of floods: U.S. Geological Survey Water-Supply Paper 1580-A, 29 p. 1964, Factors affecting the occurrence of floods in the Southwest: U.S. Geological Survey Water-Supply Paper 1580-D, 72 p.

Blaney, F.H., 1957, Evaporation study at Silver Lake in the Mojave Desert, California: American Geophysical Union Transactions, v. 38, p. 453-463.

Bowers, J.C., 1990, Potential hazards from floodflows in Grapevine Canyon, Death Valley National Monument, California and Nevada: U.S. Geological Survey WaterResources Investigations Report 89-4063, 19 p.

Bradley, R.S., 1985, Quaternary paleoclimatology: Boston, Allen and Unwin, 242 p.

Brakenridge, G.B., 1978, Evidence for a cold, dry fullglacial climate in the American Southwest: Quaternary Research, v. 9, no. 1, p. 22-40.

Broecker, W.S., and Orr, P.C., 1958, Radiocarbon chronology of Lake Lahontan and Lake Bonneville: Geological Society of America Bulletin, v. 69, no. 8, p. 1009-1032.

Brown, W.J., Wells, S.G., Enzel, Y., and Anderson, R.Y., 1989, Large-scale paleoflood events and lake fluctuations recorded in sediments from latest Quaternary Lake Mojave, Silver and Soda Basins, California: American Association of Petroleum Geologists Annual Convention, San Francisco, 1989, Proceedings.
Brubaker, L.B., and Cook, E.R., 1983, Tree-ring studies of Holocene environments, in Wright, W.E., ed., Late Quaternary environments of the United States-The Holocene: Minneapolis, University of Minnesota Press, p. 222-235.

Bullard, K., 1992, Nevada Test Site probable maximum flood study - Part of U.S. Geological Survey flood potential and debris hazard study, Yucca Mountain site: Denver, Bureau of Reclamation, $182 \mathrm{p}$.

Burke, R.M., and Birkeland, P.W., 1983, Holocene glaciation in the mountain ranges of Western United States, in Wright, W.E., ed., Late Quaternary environments of the United States-The Holocene: Minneapolis, University of Minnesota Press, p. 3-11.

Cole, K.L., and Webb, R.H., 1985, Late Holocene vegetation changes in Greenwater Valley, Mojave Desert, California: Quaternary Research, v. 23, no. 2, p. 227-235.

Crippen, J.R., 1979, Potential hazards from floodflows and debris movement in the Furnace Creek area, Death Valley National Monument, California-Nevada: U.S. Geological Survey Open-File Report 79-991, 40 p. 1982, Envelope curves for extreme flood events: American Society of Civil Engineers Proceedings, Journal of the Hydraulics Division, v. 108, no. HY10, p. 1208-1212.

Crippen, J.R., and Bue, C.D., 1977, Maximum floodflows in the conterminous United States: U.S. Geological Survey Water-Supply Paper 1887, 52 p.

Cruff, R.W., and Rantz, S.E., 1965, A comparison of methods used in flood-frequency studies for coastal basins in California: U.S. Geological Survey Water-Supply Paper 1580-E, $56 \mathrm{p}$.

D'Arrigo, R.D., and Jacoby, G.C., 1991, A 1000-year record of winter precipitation from northwestern New Mexico, USA-A reconstruction from tree-rings and its relation to El Nino and the Southern Oscillation: Holocene, v. 1 , no. 2, p. 95-101.

Dalrymple, Tate, 1970, Flood-frequency analyses, chap. A of Manual of hydrology, part 3, flood-flow techniques: U.S. Geological Survey Water-Supply Paper 1543-A, $80 \mathrm{p}$.

Deevey, E.S., Jr., and Flint, R.F., 1957, Postglacial Hypsithermal interval: Science, v. 125, no. 3240, p. 182-184.

Delfiner, P., and Delhomme, J.P., 1975, Optimum interpolation by kriging, in Davis, J.C., and McCullogh, M.J., eds., Display and analysis of spatial data: New York, Wiley, p. 96-114.

Denton, G.H., and Porter, S.C., 1970, Neoglaciation: Scientific American, v. 222, no. 1, p. 101-110.

Ely, L.L., and Baker, V.R., 1990, Large floods and climate change in the Southwestern United States, in French, R.H., ed., Hydraulics and hydrology of arid lands: New York, American Society of Civil Engineers, p. 361-366. 
Ely, L.L.; Enzel, Y., Baker, V.R., and Cayan, D.R., 1993, A 5000-year record of extreme floods and climate change in the Southwestern United States: Science, v. 262 (October 15, 1993), p. 410-412.

Ely, L.L., Enzel, Y., and Cayan, D.R., 1994, Anomalous atmospheric circulation and large winter floods in the Southwestern United States: Journal of Climate, v. 7, p. 977-987.

Enzel, Y., 1992, Flood frequency of the Mojave River and the formation of late Holocene playa lakes, southern California, USA: Holocene, v. 2, no. 1, p. 11-18.

Enzel, Y., Brown, W.J., Anderson, R.Y., McFadden, L.D., and Wells, S.G., Jr., 1992, Short-duration Holocene lakes in the Mojave River drainage basin, southern California: Quaternary Research, v. 38, no. 1, p. 60-73.

Enzel, Y., Brown, W.J., Anderson, R.Y., and Wells, S.G., Jr., 1988, Late Pleistocene-early Holocene lake stand events recorded in cored lake deposits and in shore features; Silver Lake playa, eastern Mojave Desert, southern California [abs.]: Geological Society of America Abstracts with Programs, v. 20, no. 3, p. 158.

Enzel, Y., Cayan, R.D., Anderson, R.Y., and Wells, S.G., Jr., 1989, Atmospheric circulation during Holocene lake stands in the Mojave Desert-Evidence of a regional climatic change: Nature, v. 341, no. 1, p. 44-48.

Enzel, Y., Ely, L.L., House, P.K., and Baker, V.R., 1993, Paleoflood evidence for a natural upper bound to flood magnitudes in the Colorado River Basin: Water Resources Research, v. 29, no. 7, p. 2287-2297.

Fenneman, N.M., 1931, Physiography of western United States: New York, McGraw Hill, 534 p.

Fetter, C.W., 1988, Applied hydrology (2d ed.): New York, MacMillan, 591 p.

Fritts, H.S., Lofgern, G.R., and Gordon, G.A., 1979, Variations in climate since 1602 as reconstructed from tree rings: Quaternary Research, v. 12, no. 1, p. 18-46.

Gaylord, D.R., 1982, Geologic history of the Ferris Dune Field, south-central Wyoming: Geological Society of America Special Paper 192, p. 65-82.

Grove, Jean, M., 1988, The Little Ice Age: New York, Methuen, 498 p.

Harbeck, G.E., Jr., 1955, The effect of salinity on evaporation: U.S. Geological Survey Professional Paper 272-A, 6 p.

Haynes, C.V., 1967, Quaternary geology of the Tule Springs area, Clark County, Nevada, in Wormington, H.M., and Ellis, Dorothy, eds., Pleistocene studies in southern Nevada: Nevada State Museum Anthropology Paper 13, p. 15-104.

Hedman, E.R., 1970, Mean annual runoff as related to channel geometry of selected streams in California: U.S. Geological Survey Water-Supply Paper 1999-E, $17 \mathrm{p}$.
Hedman, E.R., and Osterkamp, W.R., 1982, Streamflow characteristics related to channel geometry of streams in Western United States: U.S. Geological Survey Water-Supply Paper 2193, 17 p.

Hughes, G.H., 1967, Analysis of techniques used to measure evaporation from Salton Sea, California: U.S. Geological Survey Professional Paper 272-H, p. 151-176.

Hunt, C.B., 1966, Stratigraphy, in Hunt, C.B., and Mabey, D.R., eds., Stratigraphy and structure Death Valley, California: U.S. Geological Survey Professional Paper 494-A, p. A9-A97.

1975, Death Valley-Geology, ecology, archeology: Berkeley, University of California Press, 234 p.

Hunt, C.B., Robinson, T.W., Bowles, W.A., and Washburn, A.L., 1966, Hydrologic basin, Death Valley California: U.S. Geological Survey Professional Paper 494-B, 138 p.

Hydrology Subcommittee, 1982, Guidelines for determining flood flow frequency: U.S. Department of the Interior, Interagency Advisory Committee on Water Data, Bulletin 17, 28 p., 14 appendixes.

Kahya and Dracup, 1994, The influences of type 1 El Nino and La Nina events on streamflows in the Pacific Southwest of the United States: Journal of Climate, v. 7, p. 965-976.

King, T.J., 1976, Late Pleistocene-early Holocene history of coniferous woodlands in the Lucerne Valley region, Mojave Desert, California: Great Basin Naturalist, v. 36, p. 227-238.

Lajoie, K.R., and Robinson, S.W., 1982, Late Quaternary glacio-lacustrine chronology Mono Basin, California [abs.]: Geological Society of America Abstracts with Programs, v. 14, no. 3, p. 179.

LaMarche, V.C., 1974, Paleoclimatic inferences from long tree-ring records: Science, v. 183, p. 1043-1048.

Matthes, F.E., 1930, Geologic history of the Yosemite Valley: U.S. Geological Survey Professional Paper 160,137 p.

McFadden, L.D., Brown, W.J., Enzel, Y., Harrison, J.B.J., and Wells, S.G., Jr., 1988, Soil geomorphic studies of sequences of beach ridges of pluvial Lake Mojave and Silver Lake playa, eastern Mojave Desert, California [abs.]: Geological Society of America Abstracts with Programs, v. 20, no. 3, p. 212.

Mehringer, P. J., Jr., and Warren, C.N., 1976, Marsh, dune, and archeological chronology, Ash Meadows, Amargosa Desert, Nevada, in Elston, R., and Headrick, P., eds., Holocene environmental change in the Great Basin, Nevada: Archeological Survey Research Paper 6, p. $120-150$. 
Meyers, J.S., 1962, Evaporation from the 17 Western States with a section on Evaporation rates, by T.J. Nordenson: U.S. Geological Survey Professional Paper 272-D, p. 71-100.

Michaelsen, J., and Haston, L., 1988, Precipitation variability in coastal California; spatial and temporal components and relationships to atmospheric circulation patterns-Final report: Los Angeles, University of California, Water Resources Center Project W-707.

Michaud, J.D., and Sorooshian, Soroosh, 1994, Effect of rainfall-sampling errors on simulations of desert flash floods: Water Resources Research, v. 30, no. 10, p. 2765-2775.

Mifflin, M.D., and Wheat, M.M., 1979, Pluvial lakes and estimated pluvial climates of Nevada: Nevada Bureau of Mines and Geology Bulletin 94, $57 \mathrm{p}$.

Miller, C.D., 1973, Chronology of Neoglacial deposits in the northern Sawatch Range, Colorado: Arctic and Alpine Research, v. 5, p. 385-400.

Miller, G.A., 1977, Appraisal of the water resources of Death Valley, California-Nevada: U.S. Geological Survey Open-File Report 77-728, 124 p.

Monmonier, M.S., 1982, Computer-assisted cartographyPrinciples and prospects: Englewood Cliffs, N.J., Prentice-Hall, Inc., 214 p.

National Oceanic and Atmospheric Administration, 1969, Weekly weather and crop bulletin: Ashville, N.C., National Climate Data Center, v. 56, no. 3-4. [January 20 and 27, 1969] 1976, Weekly weather and crop bulletin: Ashville, N.C., National Climate Data Center, v. 63, no. 37-41. [September 14, 21, and 28, 1976; October 5 and 13, 1976]

1983, Weekly weather and crop bulletin: Ashville, N.C., National Climate Data Center, v. 70, no. 34.

[August 23, 1983]

1990, Climatological data annual summary - California: Ashville, N.C., National Climate Data Center, v. 94 , no. 13.

Oakeshott, G.B., 1971, California's changing landscapes: New York, McGraw-Hill, 388 p.

Porter, S.C., and Denton, G.H., 1967, Chronology of Neoglaciation in the North American Cordillera: American Journal of Science, v. 265, p. 177-210.

Richmond, G.M., 1965, Glaciation of the Rocky Mountains, in Wright, H.E., Jr., and Frey, D.G., eds., The Quaternary of the United States: Princeton, Princeton University Press, p. 217-230.

Ropelewski, C.F., and Halpert, M.S., 1986, North American precipitation and temperature patterns associated with the El Nino-Southern Oscillation (ENSO): Monthly Weather Review, v. 114, p. 2352-2362.
1989, Precipitation patterns associated with the high index phase of the Southern Oscillation: Journal of Climate, v. 2, p. 268-284.

Schick, A.P., 1988, Hydrologic aspects of floods in extreme arid environments, in Baker, Victor, Kochel, C.R., and Patton, P.C., eds., Flood geomorphology: New York, Wiley, 503 p. [p. 189-203]

Schonher, T., and Nicholson, S.E., 1989, The relationship between California rainfall and ENSO events: Journal of Climate, v. 2, p. 1258-1269.

Schulman, E., 1947, Tree-ring hydrology in southern California: Laboratory of Tree-Ring Research Bulletin, v. 4, p. 1-36.

Smith, G.I., 1979, Subsurface stratigraphy and geochemistry of late Quaternary evaporites, Searles Lake, California, with a section on Radiocarbon ages of stratigraphic units, by Minze Stuiver and G.I. Smith: U.S. Geological Survey Professional Paper 1043, 130 p.

Smith, G.I., and Street-Perrott, F.A., 1983, Pluvial lakes of the Western United States, in Porter, S.C., ed., Late Quaternary of the United States-late Pleistocene: Minneapolis, University of Minnesota Press, v. 1, p. 190-212.

Smith, N.L., and Anderson, R.Y., 1982, PleistoceneHolocene climate of the Estancia Basin, central New Mexico, in Grambling, J.A., and Wells, S.G., Jr., eds., Albuquerque County II [Socorro]: New Mexico Geological Society Field Conference Guidebook, 1982, p. 347-350.

Smith, W., 1986, The effects of eastern North Pacific tropical cyclones on the Southwestern United States: National Oceanic and Atmospheric Administration Technical Memorandum NWS WR-197 (August 1986), 229 p.

Snyder, C.T., and Langbein, W.B., 1962, The Pleistocene lake in Spring Valley, Nevada, and its climatic implications: Journal of Geophysical Research, v. 67, no. 6, p. 2385-2394.

Spaulding, W.G., 1985, Vegetation and climates of the last 45,000 years in the vicinity of the Nevada Test Site, south-central Nevada: U.S. Geological Survey Professional Paper 1329, 83 p.

Squires, R.R., and Young, R.L., 1984, Flood potential of Fortymile Wash and its principal southwestern tributaries, Nevada Test Site, southern Nevada: U.S. Geological Survey Water-Resources Investigations Report 83-4001, 33 p.

Stine, Scott, 1990, Late Holocene fluctuations on Mono Lake, eastern California: Palaeogeography, Palaeoclimatology, Palaeoecology, v. 78, p. 333-381.

Thomas, D.M., and Benson, M.A., 1970, Generalization of streamflow characteristics from drainage-basin characteristics: U.S. Geological Survey Water-Supply Paper $1975,55 \mathrm{p}$. 
Thomas, W.O., Jr., 1987, Techniques used by the U.S. Geological Survey in estimating the magnitude and frequency of floods, in Mayer, L., ed., Catastrophic flooding: Binghampton Symposia in Geomorphology, International Series 18, p. 267-288.

U.S. Department of Energy, 1988, Site characterization program manual: Denver, v. 5, pt. B, p. 8.3.1.5-94 to 8.3.1.5-101.

Vance, R.E., Mathewes, R.W., and Clague, J.J., 1992, 7000-year record of lake-level change in the northern Great Plains-A high-resolution proxy of past climate: Geology, v. 20, p. 879-882.

Waananen, A.O., and Crippen, J.R., 1977, Magnitude and frequency of floods in California: U.S. Geological Survey Water-Resources Investigations 77-21, 96 p. [Available from National Technical Information Service, Springfield, VA 22161 as NTTS Report PB-272]
Waters, R.M., 1989, Late Quaternary lacustrine history and paleoclimatic significance of pluvial Lake Cochise, southeastern Arizona: Quaternary Research, v. 32, no. 1, p. 1-11.

Weldon, R.J., 1990, Origin of fill terraces in the central Transverse Ranges, California: American Geophysical Union Transactions, v. 70, no. 43, p. 1125.

Winograd, I.J., and Szabo, B.J., 1985, Water-table decline in the south-central Great Basin during the Quaternary period-Implications for toxic waste disposal: U.S. Geological Survey Open-File Report 85-697, 18 p.

Woodburne, M.O., 1991, The Tecopa Lake beds in Reynolds, R.E., ed., Crossing the borders-Quaternary studies in eastern California and southwestern Nevada: Mojave Desert Quaternary Research Center (MDQRC) Special Publication, May 17-20, 1991, p. 155-157. 